Practical Hints ON

GRASSES AND GRASS GROWING in EAST ANGLia

BY 


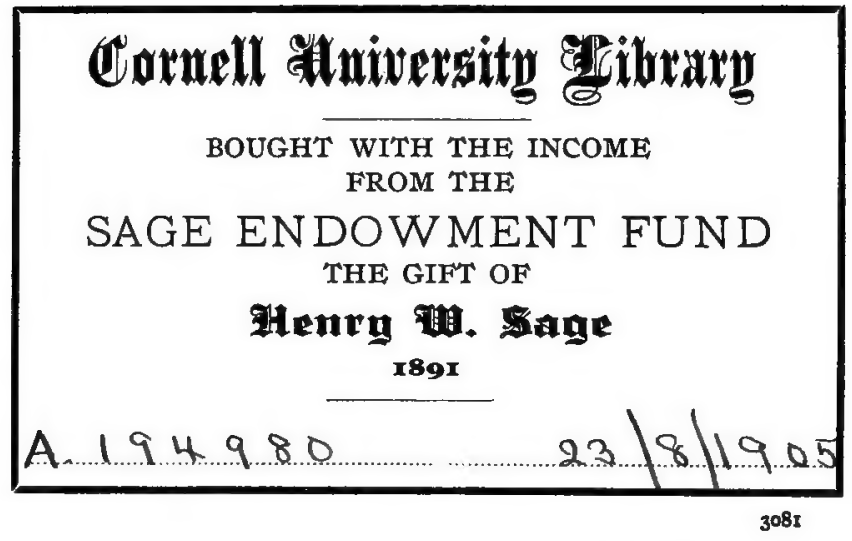

\section{RETURN TO}

ALBERT R. MANN LIBRARY

ITHACA, N. Y. 
Cornell University Library

SB 208.G7E93

Practical notes on grasses \& grass growi

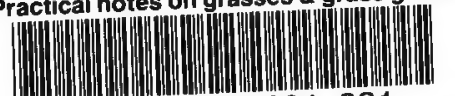

$\begin{array}{llllll}3 & 1924003 & 381831\end{array}$ 


\section{Cornell University Library}

The original of this book is in the Cornell University Library.

There are no known copyright restrictions in the United States on the use of the text. 


\section{PRACTICAL NOTES \\ ON}

GRASSES AND GRASS GROWING IN

EAST ANGLIA. 



\title{
PRACTICAL NOTES
}

ON

\section{GRASSES \& GRASS GROWING}

\section{EAST ANGLIA.}

WILLIAM SPENCER EVERITT.

\author{
EDITED BY
}

\section{NICHOLAS EVERITT,}

"H.R.E."-"Will o" the Wisp"-Author of "Ferrets, their Management in Health and Disease," elc., etc.

\section{LONDON :}

JARROLD \& SONS, IO \& II, WARWICK LANE, E.C.

[All Rights Reserved.] 



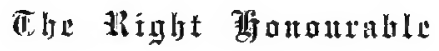
'IHOMAS WILLIAM, SECOND EARL OF LEICESTER,

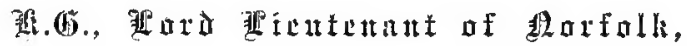
IETC., WTC.,

TIIIS WORK

IS

BY HIS LORDSHIP'S KIND PERMISSION RESTECTVUILY DEDICATED. 


\section{NOTI C E.}

Should any reader wish for the Author's advice or assistance (in order to avoid unnecessary correspondence), he will oblige by answering the following questions:-

\begin{tabular}{|c|c|}
\hline 1. & Arei proposed to be dealt with. \\
\hline$\because$. & Description of surface and sub-soil. \\
\hline 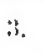 & Nature of surroundings, whether the land is sheltered or bleak. \\
\hline 4. & Inw drained, if the land is wet or dry. \\
\hline$\pi$. & I'revious crops during the last decade. \\
\hline i. & Description of recent cultivation and present state. \\
\hline$\pi$. & I'urposes for which the crop is required. \\
\hline
\end{tabular}

Address-

W. S. EVERITT,

Otlton Broad,

LOWESTOFT. 


\section{PREFACE.}

My father and grandfather having farmed no small acreage in the good old times, when wheat was eighty shillings a quarter, and the attention paid to our layers and pastures was not so great, nor the subject of such importance as it is to-day, I attempted to follow in their footsteps, taking my first farm in the year 1859 .

This farm was situated next to one occupied by Mr. W. Staines, who, it will be remembered, was among the first introducers of indigenous clover. From the very commencement of my career I took a great interest in the cultivation of grasses, and to this fact I probably owe my present position as one of the largest seed merchants in the Eastern Counties. Having thus had a considerable experience, practically and theoretically, I have ventured, at the request of many of my friends, to compile this little volume.

The work cannot be considered an ambitious one, and if my readers will grant indulgence to my shortcomings, remembering that these notes are to a great extent but a record of my own experience, I trust they will find something at least interesting, and perhaps even of profit to themselves, in the following pages.

I would state at the outset that I have no pretentions to be regarded as a botanist, and I have avoided the use of botanical 
names except where I have, for good reasons, thought it necessary to use them.

The majority of these chapters have already appeared in The Field newspaper, and it is through the kind permission of the proprietors of that paper that I am able to reproduce them.

I would tender my warmest thanks to those who have corresponded with me upon interesting questions in relation to grasses and to grass growing. From them I have learnt much which, but for their kindness, would have taken me years to ascertain by personal observation. In particular, I have to thank Lord Leicester, Lord Clifton (now Earl of Darnley), and $\mathbf{M r}$. Martin Sutton for their kindly interest in the subject whilst these articles were appearing in The Field, and whilst differing perhaps from them in some not unimportant points, I cordially admit the value of their criticisms on those questions in which we are not at one.

I would also thank my son (of Norwich) for having edited the whole of this work for me, and for the care and trouble he has devoted to it, in order that it might be placed in the hands of the reader in its present form.

\section{WILLIAM SPENCER EVERITT}

OUlToN Broat, Lowestoft, Jumury, 1897. 


\section{CONTENTS.}

\section{PART I.}

I.-OBjeCtionable AND PERNicious WeEdS-

Twitch, Couch, or Speargrass (Triticum repens) Black Grass (Alopecurus agrestis)-Running Grass (Agrestis vulgaris) - Yorkshire Fog (Holcus lanatus)-Dock (Rumex obtusifolius)Sorrell (Rumex acetosella)-Rib Grass or Plantain Seeds (Plantago lanceolata)-Buttercup or Crowsfoot (Plantago lanceolata)-Red Robin (Geranium molle) - Stone Grass - Dodder (Cuscuta trifolii)

II. - ONE YEAR'S LEY-TWO TO THREE YEARS' LEY-THE AFTER MANAGEMENT OF CLOVERS AND PASTURES

IV.-LORD LEICESTER'S ELEVEN-COURSE SHIFT 
IX.-CLOVERS -

Common Red Clover (Trifulium pratense, Linn.) Single cut Cow Grass or Perennial Red Clover (Trifolium pratense perenne, Sutt.)-Zig-Zag Clover (Trifolium medium, Hudson)-Woodland Cow Clover (Trifolium pratense, var. Sylvestre, $S_{\left.y^{\prime} m i^{\prime}\right)}$

\section{PART II.}

1.-HEAVY SEEDS-

Alsike Clover (Trifolium hybridum)-White Clover (Trifolium repens perenne)-Trifolium (Trifolium incarnatum and alba) - Yellow Suckling (Trifolium minus)-Trefoil (Medicago lupulina)-Birdsfoot Trefoil (Lotus comiculatus) -Kidney Vetch or Sand Clover (Anthyllis vulneraria) - Yarrow or Milfoil (Achillea millefolium ) - Lucerne - Sainfoin - Cinquefoil (Onobrychis sativa)-Sheep's Parsley (Petroselinum sativum) - Tares or Vetches (Vicia sativa)-Blue Lupins (Lupinus augustifolius)Yellow Lupins (Lupinus luteus)-Rib Grass (Plantago lanceolata) - Burnet (Poterium sanguisorba) 


\section{PART III.}

CHALTER

PACIE.

I.-LIGHT SEEDS-

Perennial Ryegrass, Pacey Grass, or Bent (Lolium perenne)-Italian Ryegrass (Lolium italicum)-Hard Fescue (Festuca eluriuscula)Meadow Fescue (Festuca pratensis)-Spiked Fescue (Festuca pratensis, var. loliacea)-Tall Fescue (Festuca eliator) - Sheep's Fescue (Festuca ovina)-Red Fescue (Festuca rubra) -Various-leaved Fescue (Festuca heterophylla) -Fine-leaved Fescue (Festuca tenuifolia)Smooth-stallied Meadow Grass (Poa pratensis) Rough-stalked Meadow Grass (Poc trivialis) Annual Meadow Grass (Poa annua)-Wood Meadow Grass (poa nemoralis)-Sweet Reed Grass (Poa aquatica) - Crested Dogstail (Cynosurus cristatus)-Meadow Foxtail (Alnpecurus pratensis)-Sweet Vernal (Anthoxanthum odoratum)-Tall Oat Grass (Avena eliator)Yellow Oat Grass (Avena flavescens) - Timothy or Meadow Catstail (Phleum pratense)-Cocksfoot (Dactylis glomerata)-Fiorin, or Creeping Bent Grass (Agrostis alba, or Agrostis stolonifera)-Schradus Bome Grass (Bromus schrederi) -Awnless Crome Grass (Bromus inermis) Hassock Grass (Aira cospitosa)-Dog's Tooth. Couch Grass (7riticum caninum)-Marram Mat Grass (Ammophila arundianacea)-Sand or Sea Lyme Grass (Elymus arenarius) - Esparto Grass-Nettles 

PART I. 



\title{
Practical Notes on Grasses
}

\section{and Grass Growing in East Anglia.}

\author{
CHAPTER I. \\ OBJECTIONABLE AND PERNICIOUS WEEDS.
}

Twitch, Conch, or Speargrass (Trilicum repens). Black Grass (Alopecurus agrestis). Running Grass (Agrestis vuloaris). Yorkshire Fog (Holcus lanatus). Dock (Rumex obtzisifolius). Sorrell (Rumex acetosella). Rib Grass or Plantain Seeds (Plantago lanceolata). Buttercup or Crowsfoot (Plantago lanceolata). Red Robin (Geranizun molle). Stone Grass. Dodder (Cusiuta trifolii).

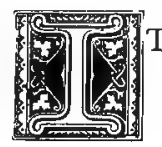

is as essential for one who would be a successfuI grass-grower to be thoroughly coluversant with the weeds which are pernicious to one's pastures, as it is for one to understand the various seeds which one is handling. We do not propose to deal with all the weeds which would fall under this heading, but merely to select a few of those which are generally a nuisance to the agriculturist and are likely to be found, sooner or later, in almost every pasture.

Taking them in the order in which they, in our opinion, make themselves most objectionable, we will summarise, as shortly as we can, some of their general characteristics, how 
Missing Page 
Missing Page 


\section{Black Grass (Alopecurus agrestis).}

This would be more troublesome even than speargrass excepting that it only flourishes on moist and wet bottomed lands. It flowers and seeds very rapidly, having a head or spike similar to timothy and foxtail, only the head of the black grass is longer and slimmer, and its seeds assimilate the seeds of the ryegrasses more than the other two we have named.

It is worthy of remark that this grass is one of the most rapid grasses in arriving at maturity, and it is an alopecurus in company with meadow foxtail, which is one of our most valuable pasture grasses, being both early and hardy, and were it not for the fact that it takes three years in arriving at maturity, it would find greater favour and be more constantly sown.

Black grass has the same peculiarity as speargrass in propagating very rapidly from its roots, so much so, that many assert that it in time turns to speargrass, but a careful observation will readily refute this. Black grass does not form so compact a mass as speargrass, and it is therefore more easily killed, but at the same time it is the more difficult to exterminate of the two.

Black grass seeds more freely and rapidly than speargrass, whilst its seed lays dormant in the land, springing up with a persistency which becomes wearisome to the most patient; and on lands congenial to it it will take years before it can be got under.

Running Grass (Agrestis vulgaris).

This grass apparently embodies the bad qualities of both speargrass and black grass; but in place of root propagation 
underground it works more on the surface, as its name would imply. In appearance it is more ruddy than either of the other two named, and very rapidly it shoots out long runners, which spread over the ground, striking root at each knob, in a manner which to those unacquainted with it is truly astonishing. If left to itself it will become similar to speargrass, but it is not so difficult to destroy.

In dealing with running grass great care must be taken, and if the land is forced by harrow and roll, any short pieces containing a knob which escape notice will take root and spread as soon as the crop is planted. Running grass is as great a nuisance to the pasture as it is to the corn grown.

\section{Yorkshire Fog (Holcus lanatus).}

This is a weed which, so to speak, comes by degrees, and nothing appears to feed on it. As years roll on it gathers in strength, and appears in the form of unsightly tussocks, which must be stubbed up with a mattock, and no time should be lost in so doing.

Although it throws out propagating roots, it propagates chiefly by seed. The seed is in appearance somewhat like foxtail, but the awn on each seed is so short that it is almost imperceptible to the naked eye; whereas the awn on foxtail seed is as long as the awn on the seed of Italian ryegrass. In colour, Yorkshire fog is a bright pea-green, and its foliage is broad and soft; but the large, numerous, and handsome seed spikes which it throws out vary very much in their colour, shape, and general character.

The ugly tussocks of Yorkshire fog can be seen in almost every hedgerow, and it flourishes in profusion on waste lands, regardless alike of the quality of the soil and the situation. It exhausts the land more quickly than almost any other kind of grass, and smothers the good seeds with which it comes in contact. 
A near relation to Yorkshire fog is Hassock Grass (AIra Coespitosa), which is a giant species of Holcus; but as it thrives only on wet soil, more particularly on peat tracks and bogs, it is not of much moment under our present heading. Suffice it for us to say, the seed may frequently be detected in "wood meadow grass" by its irregular shape, thick ends, and shiny appearance, not forgetting the white hairy fringe at the base of the seed.

\section{Dock (Rumex obtusifolius).}

In docks we find several varieties, the most conspicuous amongst them being the common smooth-leafed field dock and the crimpled hard marsh dock. We have heard it remarked that docks die of old age, but if the originator of that remark ever visits our Norfolk Broads, and takes note of and examines the venerable dock stools which everywhere abound, he will have no faith in the theory he has propounded.

Immediate action should be taken whenever docks put in an appearance, and every root should be extracted from the land. If docks are allowed to stand they soon spread themselves in all directions, the seed mingling with the hay and corn, and sheep eating the seeds (which they cannot digest) assist in spreading the nuisance. One autumn some years ago chance led us to a field in the parish of Whinburgh, in Norfolk, where we noticed some dock roots in a wheat stubble, and our attention was drawn to an insect which had eaten out the middle of the dock roots. This insect was unknown to us, and we carelessly omitted further search.

\section{Sorrell (Rumen acetosella).}

Sorrell is by no means a desirable adjunct to permanent pastures; its name implies its sour and unpalatable taste, and 
on retentive lands it gives much trouble. The seeds are very similar in appearance to the seeds of dock, but they are smaller, their edges are toned off, and they have a white speck at their nib; their shiny appearance at once betrays their presence in seed samples. Sorrell should be dug out from the pasture land and killed.

\section{Rib Grass or Plantain Seeds (Plantago lanceolata).}

This grass is only half a weed, as on light lands it is sown, and has a place in commerce, yet on good land it is a nuisance; spoiling clover seed samples, from which it is impossible to extract it after the seed is drawn from the cob. The difficulty -if difficulty it can be called-is easily surmounted by sifting before the seed is drawn from the cob. The artificial wind blows the clover cob away, and the rib grass falls directly to the ground. Rib grass seed is exactly like tiny date stones to look at, and sheep are excec dingly fond of it. They will thrive well upon rib grass, and it can perbaps with advantage be grown on land that is not good enough for much else. On these lands it will be found absolutely perennial, producing an abundance of wholesome herbage which sheep are immensely fond of; but rib grass is of little good for hay, and very difficult to make hay from. If sown, sow $10 \mathrm{lb}$. to $12 \mathrm{lb}$. per acre, mixing with other suitable seeds.

\section{Buttercup or Crowsfoot (Plantago lanceolata).}

On nearly all pastures and moist-bottomed land this yellow flowering weed is a great nuisance. Although when its roots are exposed it is easily killed with the sun's aid, jt is most persistent in reappearing, the seed apparently lying dormant in the land. Its presence denotes lack of quality in the pasture, and it is alleged that if the buttercup is eaten by cows the 
quality of their butter is not affected for the better; it is perhaps fortunate that cows will not eat it freely, if they can get anything better. This weed is to a great extent indigenous to the soil, and when once it takes root it increases and multiplies most rapidly, and it can only be eradicated by the utmost perseverance.

\section{Red Robin (Geranium molle).}

Red Robin, being simply an annual in permanent pastures, is not of much trouble, but in alternate husbandry it soon becomes a nuisance. The scythe is its most effectual remedy. In samples of white clover the presence of the seed of Red Robin is difficult to detect, and, when discovered, it is advisable to refuse to take the sample on any terms. In growth it is tall, and bears a red flower. Why it should be caller Red Robin we are at a loss to understand, unless it is named after the seed, which is of a dull reddish hue.

\section{Stone Grass.}

Stone grass, which is more commonly called "runners," does not become particularly troublesome unless allowed to obtain a strong hold upon one's land. It is chiefly found amongst giant and perennial red clovers, where it is easily detected, in the sample which it considerably deteriorates. These plants, which resemble diminutive rhubarb stools, send out long runners in all directions, hence the sobriquet quoted above. Its seeds are rough to the touch and quite round in appearance.

An easy method of discovering whether stone grass seeds are present in a sample is as follows:-Take the sample, say, of perennial red clover, which you imagine is infested with the seeds of this weed, and place it upon a sheet of smooth paper; 
shaking the paper gently, the stone grass seeds immediately become separated from the main bulk, and they will run all over the paper, telling you at once whether your suspicions are confirmed.

There exists, as everybody interested knows, machines for extracting weed seeds from samples of other seeds, but no machine that we have seen will clean or exorcise weeds from samples entirely. And, again, we would warn the intending grower to refuse samples in which he notices suspicions of obnoxious weeds.

Thirty years ago, perhaps less, gangs of women and children were wont to be engaged to weed one's farm, but nowadays this custom appears to be unknown, through new laws and school boards, and the farmer should therefore be all the more careful what he puts on to his land, as, more often than otherwise, he will find a cheap sample a dear bargain.

\section{Dodder (Cuscuta trifolis).}

The last of the weeds with which we now propose to deal is perhaps one of the worst. Like most evils it is attractive on account of the interest one cannot resist feeling in it.

Dodder, in our opinion, must be classified upon the border line which divides the animal from the vegetable world. It is a plant which feeds upon other plants, more especially upon clovers. In nature it resembles the water anemone, which is found in our rivers growing upon long sunken piles, and on the foundations of old landing-stages, whose green finger-like leaves are impregnated with a gelatinous looking matter by which it collects and closes upon its food; should the plant be severed from its hold and taken from the water and dried it emits a most offensive smell, reminding one of putrid fish. We have another weed (a water weed) which grows in our dykes, and lives upon fish spawn, fry, and vegetable particles 
which it catches upon its leaves as a spider catches flies in its web.

Dodder assimilates these two vegetarian anthropophagi, in that, when pressed in the hand, the gelatinous substance which is peculiar to them is also found in it, and if you place dodder upon a flat piece of iron, wood, or on a slab of marble, and feed it regularly with clover leaves during warm summer or autumn weather, it thrives and grows without soil and moisture which are so essential to vegetable life. Our remarks naturally refer to the clover dodder, the most common and the chief variety; there seem to be many other varieties, with which it is unnecessary for us to treat. Although dodder is one of the worst weeds we have, it is not a very serious grievance, for it only affects clover which comes but once in eight years. To get rid of it the rake must be used, and the pulled-up weeds burnt.

That the seeds of dodder lie dormant in the land we are convinced, and we have observed many instances to confirm our conviction. One case especially is fresh in our memory. Dodder appeared to the astonishment of a certain farmer on his land, which he had sown with English-grown seeds, clean and most carefully selected. He had seen no dodder there previously, and the inquiries he afterwards made told that dodder had been a stranger there for many years. He again grew his seeds, cut them, and used them without mixing other seeds with them; yet, in spite of this, dodder suddenly made its appearance in several places. Few farmers know dodder seed, or are able to distinguish it; a less number still know the seed of clover dodder, although hardly one will admit it if questioned. It is, perhaps, fortunate for us that the weed flourishes more in foreign countries than it does in our own, which is possibly accounted for by climatic influences. France seems to be more favourable to dodder than any other country we are acquainted with, and we are of opinion that (fortunately 
for us) our autumns as a rule are too damp for it to ripen. A fine hot autumn will bring it out, and when such is experienced, its appearance should be searched for, and the nuisance dealt with as soon as it is discovered.

The seed itself is very small, and in appearance more like a grain of soil ; if examined under a powerful microscope, it will be found to be an indented brown seed, of round formation. It can easily be extracted from other seeds by sifting with a silt sieve.

The infected ground is usually in the form of a circle, which gradually but surely continues to increase, the dodder consuming or smothering everything of a green leafy nature where it exists; we are glad to state that here, at least, when it has consumed the clover it seldom reasserts itself. Most of the remainder of the many weeds which trouble the pasture grown, come, we think, under the head of annuals, which we propose to deal with when writing upon "The After Management of Layers." 


\section{CHAPTER II.}

ONE YEAR'S LEY. TWO TO THREE YEARS' LEY. THE AF'IER MANAGEMENT OF CLOVERS AND PASTURES.

HE continued fall in prices and depreciation of agricultural produce is causing the majority of landowners and tenant farmers to lay down to grass more and more every year. They naturally reason that they cannot be worse off than they are at the present time, and such cultivation on their part decreases their labour bill, while the commercial value of the land remains unaffected. Upon this subject of laying down both temporary and permanent pastures, we now propose to offer some practical remarks and suggestions, and although many of our facts may not be novel to the reader, still there may be valuable hints among them which have hitherto escaped his attention.

A most careful selection should be made in the first instance of seeds suitable to the land proposed to be dealt with, and not a general mixture taken at random, nor one which is sold as suitable for all soils regardless of district. A general mixture, which the seller advocates as suitable for any land, will be found not only wasteful in use, but sometimes more a nuisance to the grower than a benefit. Like the sower in the famous parable, some will grow up and choke the others; some will not grow at all; and an even, strong, and thick crop must neither be expected nor looked for from such a selection. 
The grower must study his soil, its surroundings and situation, carefully selecting his seeds accordingly; his only alternative course is to go to a reliable, practical, and experienced seedsman, explain to him his requirements, and the nature of the soil proposed to be dealt with, and to leave himself almost entirely in his hands.

\section{ONe Year's Ley.}

The difficulty one has to contend with on a one year's ley is that one's seeds are almost invariably sown with spring corn. Now spring corn, notably barley, requires what the farmer calls plenty of mould. This is a light and pliable seed bed, which is obtained by ploughing the land early, and, after the' frost has completely pulverised the clods, and the March winds have dried the land, cultivating with grubber and harrow until such a bed is formed. Should one plough the land in a wet state, and no frost supervenes, one must harrow and roll until the big clods are reduced to smaller ones, and if under such circumstances one is unable to form pulverised soil, neither the grain nor the seeds will thrive.

Whether the bed is pliable or not is easily ascertained by a very simple experiment. Push your foot into the freshly raised mould, drawing it along a little way, and if you can easily do this you have a seed bed suitable for your purpose as far as spring corn is concerned.

It is no use attempting to force your land; your only course is to permit it to get thoroughly dry, and the first rain will reward your patience, as after a shower the clods will slake readily and freely to the touch of the roll and harrow.

Now arises the grass-grower's great difficulty; he has formed a perfect bed for his spring corn, but it is absolutely unsuited for his grass and clover seeds, and he is compelled to sow these as the grain is coming up. 
Possibly there are many who disagree with this view. To those who are of such an opinion we cannot do better than refer them to their own fields for a confirmation of our statement. If they will only walk over their own layers, taking particular note of the crop close to the fences, and especially near to the gateways, they will find the set very different to the rest of the field. When arguing this question, even with practical results before us, we have sometimes heard what we have above alluded to attributed to moist ground; but it is not so, as can easily be seen if there are any low lying and moist places in the middle of the same field. In reality it is accounted for by the fact that the land has been more trodden and become more solid in the places we have indicated than in the remainder of the field, hence it becomes more suited to grass seeds, which like a tight bottom and a fine top.

An instance may be quoted on this point. A few years ago we fed some sheep on a large oblong-shaped field. The sheep commenced to feed off the turnips in November, were close folded, and worked the short way of the field until March, when they finished and were withdrawn. As soon as they had completed a reach the plough followed (frost permitting), and the land was ploughed up the short way of the plough. Early in April, after the ploughing operations had been completed and sufficient dry weather had been experienced, we cultivated the field the long way of the plough, and athwart. The barley was sown, followed afterwards by clover seed and ryegrass mixture. When the crop had grown sufficiently to see the result, we found a grand layer on the end of the field where the sheep commenced to feed, gradually becoming worse and worse the nearer we approached the end where they had left off. At this end of the field the set was so bad that we ploughed the ley up. We had sown all the seed on the same day, and worked all the field in the same manner, which clearly proved to us that seeds, in some seasons, will 
not grow at all on land that has been forced, as was the case on part of the field we have alluded to; whereas, had we been patient and prepared a better seed bed we should have had a better layer, but should have been too late for the grain. This is but one of many examples we could quote in which the farmer has such difficulty in getting good crops of both seed and corn when they are sown together. What he generally does is to cultivate more in particular for the grain, sow his seed the best way he is able, and curse the weather, or the merchant from whom he purchased his seeds, when disappointment occurs.

With regard to the selection of one's seeds, the first thing to ascertain is the particular bête noir of each variety, and to be careful when scrutinising samples to see that it is absent from the parcel chosen. We believe we are right in asserting that more weeds are propagated by farmers selling their seeds to one another, neither the buyer nor the seller recognising nor having the power to remove the objectionable matter did they know of its presence. But when the grower offers his seeds to a merchant seedsman, if it is a desirable lot it is usually bought at once; but if it contains pernicious weeds, has been frosted, heated, or consists mainly of shrivelled flat seeds, if the merchant knows his business he refuses to entertain it at any price. The grower then has recourse to a second-class man, who will buy anything at a price, and the sceds become worked off somewhere to lovers of cheapness; or else the seller falls back upon his neighbours and friends, more often with disastrous results to both. A thorough knowledge of grass and clover seeds is what few indeed can boast of. There are so many varieties, they are grown under such varying conditions, climatic influences which sometimes entirely alter their character, and they grow so differently upon different soils and under different circumstances, that many questions onnected with them will always remain highly controversial. 
The man of common sense will gladly avail himself of the knowledge of others, and, however much he may have studied the subject of a good selection, he remembers that good seasons, good cultivation, and good management are also necessary for good grasses. The rough and ready rule-ofthumb management is no use; grass growing proper is an art in itself-we would almost go so far as to say it is a science; and so uncertain is weather and growth that, even with the best seeds and the best of management, success is never a certainty.

In the selection of varieties, we hold that local knowledge is absolutely necessary. Certain descriptions of seeds are adapted to one particular locality, and will not thrive in another, the reason for which is not at all times clear. The quantity of seed per acre also varies under various conditions and circumstances, sometimes in such a manner as would be astonishing to the uninitiated. For example, it is an old adage that "a peck of heavy and a peck of liglit per acre" is the proper quantity to sow for one year's ley, and the farmer of the old school, when the question is discussed, goes further, and adds, "Well, you may say what you like, but it was my father's custom, and so it shall be mine." Now a peck of red clover is quite as good a seed, if not better, than double the quantity of trefoil, and as ryegrass is invariably fit to cut for hay before clover, and as clover is such a tillering plant, not half so much ryegrass is required to mix in clover as in a trefoil mixture.

Twelve pounds of good red clover (about three-quarters of a peck), and $\mathrm{I} \frac{1}{2} \mathrm{lb}$. to $3 \mathrm{lb}$. of perennial ryegrass, will be found a fair seed in many cases; but if the land is rough more may be necessary, and, if there is any doubt or fear of clover sickness, $4 \mathrm{lb}$. of alsike, or white clover and alsike, may, with advantage, be mixed with it. Many mix trefoil with clover, but we strongly deprecate this practice except in special cases, 
because it must be remembered that trefoil is fit to cut some ten days earlier than clover.

On land which will not grow clover well, ten years' interval is good, but where this cannot be entertained and trefoil mix. ture is undesirable, we recommend the perennial cow grass, or a mixture of half clover and half cow grass, which also app'ies to doubtful or clover-sick land. On heavy or retentive land the cow grass and clover will probably be found the best mixture, but on light lands the alsike, trefoil, and white clover mixture will do best.

No sane man, however, would think of growing anything else when he was sure of his clover.

Trefoil, or, as it is commonly, called, "the black and white mixture," black inferring the black seed pods of the trefoil, and white the white suckling, is properly mixed by adding to $24 \mathrm{lb}$. to $32 \mathrm{lb}$. of trefoil, $2 \mathrm{lb}$. to $4 \mathrm{lb}$. of white suckling, and $6 \mathrm{lb}$. of perennial or pacey grass, or $12 \mathrm{lb}$. to $16 \mathrm{lb}$. of Italian. 'This is sometimes varied by adding to the white suckling, or replacing it with a little red suckling, which, if the spring happens to be wet and cold, will be found of great advantage. But if the spring be dry the red suckling will make a poor show. Where the feed is not required on a trefoil stubble, or if the land requires cleaning, it is an excellent plan to break it as soon as the hay is off, and, if one is fortunate enough to obtain sufficient moisture to bring the seeds up, sow during the month of July three bushels of spring tares with or without one bushel of barley bere. This will cover the land and produce either autumn feed, silage, hay, or soiling food. It comes on about Michaelmas, just at a time when second crop clovers are over, and cut daily and given with old hay is appreciated by every kind of stock. Should you not require the produce at all, plough all in, and such a course will be found equal to a heavy coat of manure, as the tares will collect nitrogen from the air and deposit it in your soil instcad of the 
sun being able to draw the nutriment away day by day from its naked surface.

These black and white leys may sometimes be left down a second year with advantage, but an advantage is seldom gained should clover be so left, because it seems that in a favourable season clover will extract the accumulated wealth of eight years of certain ingredients ; therefore under the most favourable circumstances the results of the second year's crops will be highly disappointing, unless perchance the yield from the first year be a poor one. We have tried this experiment many times, and a lesson has been taught us by bitter experience which we have dearly paid for.

We have now dealt with the general mixtures for spring sowing for one year's ley, omitting mention of fancy mixtures, which should only be tried under exceptional circumstances and conditions. We have still the one year's ley of catch crops to deal with. First of all comes trifolium, which is sown during the month of September on a bare stubble, and in an ordinary season requires no burying, and sheep, if turned on to the stubble at seeding time, are an advantage to it, as they pull off any extraneous weeds. A Cambridge roller or chain harrows, can be used with advantage, and they should be brought into requisition as soon as possible after the seed has been sown. Italian ryegrass is sometimes used as a mixture, or sown alone as a catch crop, and it should be used off in time, to sow turnips, but this seed requires more burying unless plenty of moisture be in evidence. Red suckling is sown on l'ght-landed soil before the corn is cut or after it is garnered, and a crop of hay or seed is thus secured the following June. Sainfoin and lucerne are more of a permanent nature, the former being drilled across and across (over wart) in a corn drill in April, four bushels to the acre, the latter being cultivated by itself, of which we propose to speak hereafter. 
Kidney vetch is only used on the very lightest of land, which may also be said of lupins. Of the latter, it may, perhaps, be regarded as a cause for congratulation that the seed is known to but few indeed. This remark will be appreciated by many an agriculturist in the neighbourhood of Thetford Heath.

In choosing seed the best that can be obtained will in the long run be found the cheapest, excepting, of course, fancy or show samples. It is our experience that the same value of the best seed produces a superior result to the same value of an inferior seed. A good, well ripened seed of rotund nature contains, as a rule, the most vitality, hence it not only produces the most fruitful plant, but also a seedling which will stand more hardship than one produced from a weaker seed. Little does the uninitiated think how easily his eye can be deceived in this respect.

As an instance of this, the most pleasing, the most brilliant, and by far the most attractive sample of white clover to look at is that which has been cut before it is ripe; a brown sample, provided it be the brown of sunshine and ripeness, is far more valuable to the grower than the one last mentioned, but when the brownness has been produced by exposure to showers the result is different; here it is that the field for judgment and the eye of the expert tells its tale.

Red clover seed should be purple and round. Yellow seeds are not so good as brown, more especially when the former are flat in shape, and the seed of the red clover should come from a cold, exposed climate, the seed from a southern clime often leading to disappointment. This applies to most seeds which are best worked southward, as, indeed, is almost anything in nature, certainly in the vegetable world.

In a sample of trefoil one must look out for the seed of the wild trefoil, which is an inferior seed, easily detected by its aroma. We would recommend buyers to give a preference to 
English seed. They are often persuaded to take a parcel which, on inquiry, will be found to come from Luxemburgh or elsewhere. But French sainfoin is, in our opinion, better than English, if the sample be free from burnet, English sainfoin being often contaminated with blubber grass. French trifolium also will be found better than English if the sample be fine. It comes best from the Beauce district, and the same may be said of lucerne which comes from Provence.

$A$ word as to mending inferior and unsatisfactory leys, and we will bring our remarks under this heading to a close. The following is a good rule: "Mend, but never plough up." There will almost always be found some sort of a crop, even if it is scarcely discernible, and, should it be very bad, sow I $2 \mathrm{lb}$. to $20 \mathrm{lb}$. of trifolium in September, and let the land rest, excepting, perhaps, a Cambridge roll be run over it. If you disturb the land you will in all probability destroy what few tender plants there may be. On cutting the trifolium in June, if there is no bottom plough it up and sow tares, and treat as before described. Should there be half a plant, sow a mixture of either red suckling, alsike, Italian ryegrass, and white suckling, according to circumstances, and hope for the best. If the ley be patchy, sow above the last-mentioned mixture a small spray of clover or trefoil, and, if treated as we have suggested, you will, in nine cases out of ten, be glad you did not destroy the ley, and by so doing put not only yourself, but the land also out of temper, thereby raising a source of irritation and disappointment, lasting until every thing has had time to be put in order again.

A new ley should never be fed in the autumn, unless it is very long; even then it must not be fed hard, and only with cattle, as sheep and horses bite too close ; and, remember, it is not what they eat, but the young plants they bruise and spoil, which so seriously impairs the spring vigour of the crop. It is a great disadvantage to have a young clover ley too vigorous 
in the autumn, and one hardly knows what to recommend. The best advice we think we can give is to let it alone, and allow nature to work its course, checking the extraneous growth with the scythe at intervals, if such action is considered necessary.

\section{'Two to 'Three Years' Ley.}

The growing popularity of two and three years' ley is, without doubt, due to the fact that the alternate growth of roots and grain so exhausts the nitrogenous properties of the soil, that paying crops cannot be produced without liberal applications of manure or other costly dressing. This is further encouraged by the increasing expense of labour and the diminishing value of produce.

The subdivision of large farms into small holdings, so often advocated by the theorist, is not practically successful, except in the neighbourhood of towns; even there it has already been overdone, and many an occupier of small holdings ruined because the market has been glutted with such stuff as he 'produces, or his market has been forced upon him.

Two years' ley is happily exempt from this last-mentioned disaster, provided the grower can hold his hay.

On many farms it is customary to keep a one year's ley down for a second year, but this course seldom succeeds unless the ley be renovated and strengthened in the autumn with suitable dressing; even then success is not certain. We should not recommend the course ourselves, but, if followed, great care should be bestowed upon the land so dealt with. There is this advantage, that when it is successful, it in a measure recuperates the land.

On a two years' ley the farmer grazes his stock, often feeding them with cake, grain, meals, or other artificial foods highly beneficial to the land, and when the sward is turned in and 
allowed to decompose, a succession of excellent crops to alternate husbandry may be expected.

It is a practical fact that permanent pastures always flag during the third or fourth year, but with temporary leys as soon as this flagging becomes apparent the farmer either carts a good conting of manure on to the land, or dresses it with road scrapings, the cuttings from banks, or he ploughs it up altogether, and saves himself further bad years. With a one year's ley this difficulty is not so apparent, nor is the seed so costly as that of permanent pasture, because the finer and dearer grasses, which take years to establish themselves, are passed over for coarser, cheaper, and less permanent substitutes.

On heavy land a simple mixture of perennial cow grass, Italian ryegrass, cocksfoot, and similar seeds are often used as a shift course; and on lighter land a simple mixture of common sainfoin and lucerne finds favour. We have known the latter to stand successfully for years.

For a good ley it is essential to have good seeds and careful cultivation, remembering that, although the use of the roll may be detrimental to the growth of barley, it is (except when the land is wet) the best friend to young grasses.

\section{The After Mlaxagenent of Clovers and Pastures.}

If a ley has been sown with a corn crop in a more or less loose and unsuitable bed, much damage may occur to the ley before the corn is harvested and the young plants can be properly attended to. This fact should be remembered, and so soon as the corn is harvested immediate attention should be given to the ley. Where the ley is weak, re-sow it with no sparing hand, and endeavour to thoroughly consolidate the soil with a roll, heavy in accordance with the nature of the land and the season. 
It is a matter for regret when this precaution is neglected, as is so often the case. As a general rule, in re-sowing more regard is paid to the farmer's convenience than to the special circumstances of each individual case, and then astonishment is expressed that the layers have not done better.

We would here impress upon our readers the importance of the roll and the scythe, which may well be designated "the seedlings' friends." The roll consolidates the land, and enables young grasses to get a grip on the soil, which is essential to their welfare; at the same time it retards the growth of speargrass.

The scythe, provided it does not cut too closely, cannot be used too often. With it are destroyed thistles, poppy, charlock, and other annuals and weeds, whilst its use strengthens the growth of young grasses and clovers, which require checking when they exhibit signs of the very weakening process of flowering. It is easily observed how dwarfed are those plants which flower or seed too early.

From the foregoing remarks one would rightly judge that as soon as the layers can be got at, they should be freely swept with the scythe, and rolled whenever necessary.

On a one year's ley, sown with rapid growing and coarse grass seeds, it is well known that if the seedlings flower in the autumn there will be but a poor crop in the summer when it is required.

Many argue that the layer will be more benefited by feeding it with cattle or sheep in preference to using the scythe, but we would remind them that the moisture which causes the superfluous growth at the same time softens the soil, and the weight of cattle will jam up the land, and squeeze in and bruise the tender young clovers and grasses, much to their detriment. So far as sheep are concerned, they are, if anything, worse than cattle, for although they may not bruise and jam in the seedlings so severely or fatally, yet they do more 
general mischief by feeding the grass too closely, and they eat away the entire crown, leaving nothing but the roots, which the air and sun soon destroy. The observer will also find another disadvantage of grazing sheep upon his young layers on account of their partiality for the youngest and tenderest of the grasses, which they pluck out with a jerk peculiar to their habit of feeding, and if the seedlings have not got a firm hold many of the best and youngest plants will be plucked out and eaten roots and all. It is for these reasons we advise the scythe and roll, and deprecate feeding down with stock.

The judicious handling of old pastures rests on somewhat similar lines to what we have named above; if they are handled differently what has been a good pasture will soon become next door to worthless. Old pasture should be fed two or three times each summer, first by fat or dainty mouthed cattle, next by rougher and hungrier cattle, and then by a flock. Moderate the feeding in accordance with the weather; during drought it may be advisable to withdraw from feeding it altogether, but in wet weather, and when the pasture is growing freely, it can hardly be too closely fed. Afterwards the chain harrows should be run over it, the molehills and droppings of the stock scattered, and the field closed for three or four weeks. A strong, regular sward of fresh nutritious feed should be the result of this treatment, and in one summer the pasture should improve so much that it may be mown with impunity the next.

It will be remembered that certain grasses are more particularly feeding grasses, others are more particularly mowing grasses; hence the necessity for the hungrier animals, in order that the mowing grasses, which are not so much appreciated for feed, may be cleared off evenly with the others.

On good land a pasture may be laid down to mow almost every year, but the land must be really good to do this, although it is sometimes done on inferior land when it has 
been deftly handled between July and March, and farmyard manure (green manure will be found to answer best) applied during the three winter months. The earlier this is applied the better.

Moulding is also a grand thing to recuperate pastures, provided the mould be good, although almost anything is better than nothing; but mould should not be carted on to the pasture during wet weather. Old banks are excellent for moulding, and will be found beneficial to any land; roadscrapings are better still, especially on stiff land: but on scalds, marl, and clay will be found to answer best. The saline deposit from the sea (where procurable), in our opinion, is the best for all lands; whilst the mud and cleanings from ditches and ponds, which has been allowed to lay a year and been twice turned over and mixed with gas-lime, forms another excellent dressing which we should not like to omit to mention.

The moulding should lay roughly on the land until the spring, when it may be pulled about with chain harrows until, practically speaking, it disappears.

Should the pasture be weak, or there are grasses which appear capable of improvement, a re-sowing should be made before the last harrowing, and the land rolled with a heavy roll.

We contend that a third-class pasture can often be converted into a first-class one in eighteen months or less, by the treatment we have above described, and if lambs, hoggets, or tegs, are folded on it ; the sheep being fed with roots, hay, and corn.

We will quote one experiment made on a third-class rough marsh pasture having a peat bottom, the sub-soil, some $2 \frac{1}{2} \mathrm{ft}$. below, being clay ouse. In the auiumn the rough rushes and grass were cut close down, during frosty weather forty load per acre of heavy soil was carted on to it, and 
spread evenly over the surface; as soon as the spring winds had dried this moulding, renovating seeds were sown, roots and corn carted to the field, and hoggets were folded on it. This formed a crust, and the nature of the pasture was completely and permanently changed for the better; the rushes also entirely disappeared.

Another spring experiment was tried on a marsh, where the clay ouse sub-soil obtained by cutting a new drainage dyke, was utilised as moulding. Here the beneficial results were still more striking.

On a subsequent accasion hoggets were folded and fed during a dry October, but this time the results were most disappointing, and the pasture was injured.

Should the farmer have no empty cows, in calf heifers, or other hungry stock, we would recommend the use of salt, which can be sown over the rougher portion of the pasture. This often induces the cattle to feed there. Daily he should cut the rougher places, mixing the herbage thus cut with old hay, chaff, and salt, and laying it in a lump for a day or two until heat commences to generate, then add corn or cattle meal, and feed the grazing aninuals with it, providing a trough (if it can conveniently be done) for each. We have utilised petroleum casks cut in halves, and rough boxes knocked up from any odd boards for this purpose. When these troughs are first introduced the master bullock will run from box to box, but if they are placed wide apart he will soon learn from experience that his journeys are not productive of satisfactory results, and he will be content with the first box he comes to, or a box to which he shows a particular preference. The boxes may then be put closer together.

We would also advise the farmer to move his boxes daily, and strengthen them by cross pieces on the bottom; besides, this raises them from the ground, and has other advantages.

By feeding thus there is no waste. Some advocate cake in 
preference to other feeding stuffs, but we are strong advocates of meal, regulating the constituents thereof according to weather and the herbage, and at the same time exercising the teachings of practical experiments savoured with theory, which is invariably the course adopted by prudent men.

When writing on alternate mowing and feeding, we touch a very controversial subject. Many farmers declare this practice impossible without in a measure destroying their pastures; but practice proves the contrary, at least when the mowing is properly conducted. After mowing feed down well, and whenever convenient lay a flock, which have fed elsewhere during the daytime, upon the meadow at night, or the flock must be well fed whilst it is on the meadow.

During the winter months, the meadow should be liberally dressed with manure, well harrowed, and rolled in the early spring ; but this practice must not be carried on year after year, or many valuable feeding grasses may be destroyed, and it would be difficult to return to the alternate system, unless these feeding grasses were renewed by the re-sowing of suitable renovating mixtures. A pasture which is required to be always mown, or one which is required to be always fed, must be laid down expressly for the purpose for which it is required, whereas the alternate mowing and feeding requires, and will keep going, all grasses suitable to the particular kind of soil on which they are sown, and the selection of the seeds entails no little skill to ensure successful results.

If a pasture is troubled with weeds, the roll and the scythe should be used with perseverance and a will, which soon shows effect; but moss is not so easily disposed of, because it grows mostly in the winter, and thrives better where the meadow has been best farmed and left closely fed or mown down in the autumn.

One way to deal with moss is to cover it over with farmyard manure or mould, which when well jammed in by stock in the 
42 PRACTICAL NOTES ON GRASSES AND GRASS GROWING.

winter will prevent it from growing, and will render the grasses so vigorous that they are enabled to outgrow the moss in the spring. Unfortunately, our experience tells us that when moss is apparently exterminated from land in clue time it appears again, if at all neglected, as bad as ever; but one must not be discouraged by this, as perseverance generally masters all things in the long run. It may be as well to also bear in mind that strengthening the soil encourages grass and weakens moss.

When horses have been grazed for some time on a pasture it is imperative to follow them with cattle, or the pasture will deteriorate in a few years beyond recognition; and for the reasons we have before alluded to sheep should always follow and not precede any other kind of stock. A pasture must be fed evenly, otherwise the best grasses die out whilst inferior ones flourish, and, as a result, a first-class pasture sinks to the third or fourth-rate level.

In the management of pastures one must avoid above alk things jumping at conclusions, and one must not rest satisfied. with first or even second results, because seasons vary so much in our tight little island that it takes many years of careful observation to arrive at true deductions. 


\section{CHAPTER III.}

PERMANENT PASTURE.

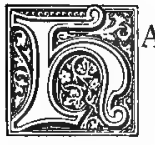

AVING cultivated entirely for the grain crop and sown the one year's ley in an unsuitable seed bed, perhaps half smothered by the growing corn, it should be the good husbandman's duty, as soon as he has completed harvest, to look after the young layer. Why it is that this point so often escapes attention astonishes us not a little.

No one would think of letting their children run wild without taking them in hand and getting them well under control, until, say, they arrived at the age of twelve or fourteen years, and at the same time expect them to do as well as those whose minds had been prepared to receive a suitable education. In the same manner the farmer cannot reasonably expect his seeds to do well after their root bed has been neglected for an entire year, unless he at once takes the matter in hand, and does all he can at the earliest possible opportunity. It is astonishing to us how well the layers do succeed, when we consider the negligent manner in which they are generally treated.

After harvest is over the layers should be most carefully examined, any spots that are found to be weak should be at once renovated, and the field consolidated by such a liberal use of the roll as may be thought necessary. On no account 
put this off until the spring, as is so often done, because it will be found too late to avoid the mischief which will have occurred.

Although it is so desirable to have a loose bed for spring corn, it does not seem to be generally known that, if the season be dry, such corn will thrive best, and stand firmer in fairly compressed land than it will in a too loose or too light bed. On this point we anticipate a difference of opinion, as the process must be modified considerably according to the land, circumstances, season, and situation; and we venture to assert that bush harrowing is a great help, not only to the grain crop, but also to the young grass seeds. As a general rule, bush harrowing is anything but judiciously done, especially in the spring, and more often it tears, bruises, and injures the young and tender plants than it does good to the crop. Also in mending and trying to bury the renovating seeds, great judgment must be exercised, in order that more seedlings are not disturbed and spoilt than are added to by the new sowing.

Under ordinary circumstances, and in what are known as the good old times, now long since departed, it would have been only proper to have said, first select the land which is suitable for a permanent pasture before you commence to lay down; but nowadays, so great is the tension of depression on arable land, that, suitable or unsuitable, the land has to be laid down, or in many places allowed to go out of cultivation altogether.

The land most suitable for permanent pasture seeds is that which has the combined qualities of being retentive, moist, and generous. On light lands, if the season be dry, good results cannot be expected, and one may find absolutely nothing at all unless grass seeds, which will naturally resist drought, be included in the mixture sown.

On moist soil it is different. Let the land be ever so good, 
if it is water slain, nothing can or will thrive that is of good value for feeding purposes. The reason is apparent; no land is so cold as that which is thinly covered with water, and the action of the sun's rays renders it still colder, although one would not perhaps think so. A simple little experiment will soon prove this. Let the dubious one take a jar, fill it with water, wind tightly round the outside of the jar a flannel saturated with moisture, set it in the sun, and take the temperature of the water in it. After an exposure of some little time, again take the temperature, and it will be found to have fallen several degrees. Too much water will check the growth of plants which love moisture in reason; but drain your land, giving the moisture from heaven an opportunity of percolating through the soil instead of accumulating upon, or close beneath, the surface, and you will put all vegetable life into active operation. Rain collects the oxygen and nitrogen from the air, and when it percolates through the soil vegetable growth intercepts and absorbs it, scarcely losing a particle of the goodness it contains. Capillary attraction, or the drawing up of moisture from the subsoil (as a tree will suck it up by its roots, conveying it to its topmost branches), is arrested by stagnant surface water, but on drained lands this capillary attraction proceeds during a drought to the great advantage of the crop. Another simple experiment will illustrate this. After a drought place a piece of linoleum, or floorcloth, on the dryest of land when the sun's rays are on it. After a time take it up, and you will find that that side which has been placed face downwards will be damp, and the earth underneath it moist as well. On drained lands nature spreads her cloth of verdure over the surface of the soil, which has the same effect on the elements as the experiment we have quoted. A supply of moisture is drawn up from the sub-soil, which moisture is more or less laden with chemical compounds of assistance to plant life, and thus it is that by experiments 
and practical experience we ascertain the ways and means by which we may assist the laws of nature, and the folly of our trying to resist them. Again, one knows that fallen rain, impregnated with air, percolating the soil, causes decomposition to progress, not only with spent vegetable matter, but also with mineral matter, thus developing a further food supply to growing plants, which will not take place where the land is undrained and stagnant water allowed to collect. This also we will exemplify. If a post which has been deeply sunk into the ground be dug up after several years standing, it will be found that decomposition has been most active where the sun, wind, and rain have had full play, whilst that part of the post which has been sunk deepest, and where the sub-soil was wettest, will be found the soundest. So great is the power of resisting decomposition where neither air nor light can penetrate that a freshly severed branch of a tree sunk deeply in water, or buried deeply in wet ground, will be found after, say, forty years, as fresh and green as the day on which it was cut; but when once dried, or partially dried, decomposition will start and cannot be arrested, only delayed.

Another advantage of draining is that the land so dealt with not only absorbs, but retains the sun's heat; and it will be noticed that the badly drained spots in a field are the first to succumb to heat as well as to cold, the plants growing thereon become starved, and their roots rotten.

'To the importance of the arterial drainage of one's pastures, we would add that it is most desirable to so arrange the water supply that as little water as possible runs off the surface upon which it has fallen, but at the same time no stagnant water must be allowed to accumulate. The under drains must be so deftly arranged in accordance with the nature of the land, and its slopes, that the water does not run into the drains too quickly, so that the crop on the land has not sufficient time to rob it of the valuable ingredients; nor 
on the other hand must the under drains be placed too deep, nor so far apart that the water lies dormant, and renders the land partially water slain, which as before mentioned is fatal to all plant life.

Having planned and laid the drains as they should be, fenced and ditched where necessary, our next consideration is cultivation.

In the early autumn the surface must be well broken by steam, or horse power, and the large clods gradually reduced by each successive working, until late in the autumn you will find you have either killed all the obnoxious grasses and weeds, or you will have worked them on to the surface where they can be allowed to remain until the first favourable opportunity after Christmas, when an experienced ploughman, with skimmers on the plough, will plough the land and bury everything.

With the March winds the land becomes thoroughly dry, and a light roll may be run over it, followed by seed harrows with thick and short teeth which cause thousands of annuals to appear. Continue this process at short intervals (sometimes as many as three and four times) until the stock of annuals seems exhausted. About the middle of April advantage may be taken of the first spring showers to sow seeds. These should be sown in two sowings, the first lengthwise of the field, the second across, no part of the land being missed. The land should then be thoroughly horse hoed, every part being cut, and this is followed by the seed harrows. The surface is then carefully scanned and any objectionable weeds, roots, or seedlings removed. The surface drains are cleared, and it will not be found amiss to provide the drain slusher with a bag of seeds to sow on any part of the layer which he may be compelled to disturb, or that he is of opinion would be benefited by a little further sowing. As soon as the surface is dry enough, roll down the land, and all will have been done 
that lies in your power to make the permanent pasture a success,

Without doubt the most difficult problem in connection with permanent pasture lies in the selection of seeds, and we should but mislead were we to attempt to recommend general mixtures as suitable for any or all soils, whether they be light, heavy, medium, wet, or dry.

We have no hesitation in asserting that there is scarcely a single grass which is suitable for all soils. In selecting a mixture for one's pasture one must therefore make allowances for the sub-soil, the probable exposure of the land to cold winds, hot sun, or to shade from trees, and for any other circumstances which are likely to prove factors in the question of selection.

Each field intended to be laid down to permanent pasture should have a mixture selected especially for it, and it more often happens that the soil varies so much in one field that. two or more prescriptions are necessary. But where the field is spotty, whether the spots have been directly caused by scorching of the sun's rays or by too much moisture, the same mixture is generally sown all over the field, and another mixture or mixtures especially prepared for the faulty places, which are resown.

The purpose for which the produce is required is another matter which must not be forgotten when the seeds are being: selected, and the mixture will of course vary according to whether you wish to produce ornamental sward, fine, ordinary, or coarse hay, early or late feed, quantity, and quality; and whether grazing is required for horses, cattle, or sheep.

The growth of each variety is one of the most important points to be studied and remembered, or the coarser seedlings will crowd out the better kinds, and thereby make the pasture of little or no use. An example will speedily be found if an experiment is made with cocksfoot. On some lands this grass 
takes complete possession; besides, it remains in the land. If too much cocksfoot is sown, the other seeds in the mixture will be wasted, and money would have been saved had they never been purchased. Italian ryegrass is a similar plant, but it has this difference, instead of remaining in the land it will disappear in a few years, having first smothered many of the fine grasses that have been planted with it. Red clover, good as it is, if added to mixtures for permanent pastures, will, in a measure, be disappointing in the same manner that we have mentioned the two grasses above; hence great judgment is required, not only in the selection, but also in the apportionment of the relative quantities of the seed to be used.

Our English seasons are as fickle and changeable as a sandy sea beach, and a little luck is required to obtain all the right seeds for any particular season. For instance, florin, or red suckling, sown in a dry season will produce little or nothing, no matter how thickly the seeds may have been sown; but in a wet season half the quantity of seeds used in a dry season would be sufficient to have caused either of these plants to have taken complete possession of the land to the temporary exclusion of some, and permanently smothering other grasses. Moral, the coarser grasses and clovers must always be used with caution.

The weight of grass seeds varies from $\mathrm{I}_{4} \mathrm{lb}$. to $28 \mathrm{lb}$. per bushel. Calculations, therefore, should be taken on the basis of a pound, and measures should be discarded. In calculating the number of germinating secds a 'somewhat controversial point is touched. It is calculated that in some grasses there are as many as from two to three million germinating secds in one pound, whilst in others there are but hundreds of thousands. In trefoil there are supposed to be 300,000 germinating seeds, whilst in red clover but 225,000 . Now it is a well-known fact that I lb. of red clover will go as far as $2 \mathrm{lb}$. of trefoil, and the reason is not apparent till we 
experiment, when it will be found that red clover spreads out tillers and branches, whereas trefoil is sluggish, and only flourishes under the most favourable circumstances.

In mixing seeds as much care should be used as in sowing them. Having drawn up the list and obtained the requisite quantities, carefully weigh each, in order that no mistake be made, spread each variety out thinly on the floor of the barn or granary, one on the top of the other; round them into a long-shaped heap, and turn them over and over until thoroughly mixed. One turning is not sufficient, and three at least should be made. It is best done by a couple of men with wooden malt shovels working opposite to each other, so near that their spades meet at every effort. As soon as they reach the end of the heap, the men round it up with the shovel and the broom, and recommence to turn it. It is then bagged, tallied, and labelled, the label being marked to show all details. It is also advisable to so regulate the quantities that there is some over in case any part of the land may require re-sowing at a future date.

Some agriculturists believe in sowing the heavy seeds, such as clovers and lucerne, together, and the light seeds by themselves, but we fail to see the force of their argument. One of the reasons put forward is that the wind blows the lighter sceds away more than it does the heavier; but we contend that would be the case however they were sown.

True grasses like deeper burying than heavy seeds, but this is a rule not without its exception; we would recommend the ground to be gone over twice, the land being properly prepared with a bed firm below and fine on the top. Harrow gently, and you will probably be more successful than the man who takes less pains to cultivate his land, and who tries afterwards to sow his seeds at different depths to suit their individual requirements.

I-and agents have a great advantage over others in learning. 
to master this most difficult science of successfully handling permanent and temporary pastures. They have access to the books of a variety of agriculturists, in a variety of districts, and under a variety of circumstances. They are daily brought into contact with men holding different views upon the subject. They daily see both old and new pastures, and they have opportunities of ascertaining their history and all about them. If a gentleman from this profession be met with, who has taken an interest in the subject, who is a fair-minded man and one of common-sense, and who does not, in his own opinion, know so much already that he is above hearing the views of others, he is indeed a most desirable acquaintance, and one whose assistance and advice should be courted by his less fortunate or less experienced agricultural friends. 


\section{CHAPTER IV.}

\section{LORD LEICESTER'S EIEVEN-COURSE SHIFT.}

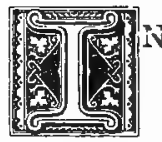

the early part of the present century (about I837), Mr. Thomas William Coke, M.P., known as "Coke of Norfolk," and distinguished as the greatest agriculturist of his day, was, we believe, elevated to the peerage and title of Earl of Leicester and Viscount Coke, solely on account of the great benefits he had accorded to the agricultural industries in this country. $\mathrm{He}$ it was who introduced the four-course shift system of alternate husbandry, and as we write we note that the present and second Earl of Leicester is brought into prominence by the depression in prices of grain, and by the consequential failure of the very system which his father had before him so successfully introduced.

The present carl is, in our humble estimation, as great, if not greater, an authority upon things agricultural as his father was. He has for years been experimenting upon temporary pastures, and has recently, at the instigation of $\mathrm{Mr}$. ShawLefevre, expressed his views in the Times.

The conclusions drawn from his observations seem to show that only the finest and most productive land can now be advantageously farmed under the "four-course shift system," the weaker and poorer land requiring more manure than the produce will repay. In the latter case recourse is had to pastures, laid down with a mixture of more or less leguminous. sceds, which, in a few years, aided by the stock grazing thereon, 
cause or permit the land to accumulate a sufficient store of nitrogen and other fertilising qualities, and render it capable of producing the four years alternate course before referred to.

Vith all due respect to his lordship's opinion, we would suggest that the interval, before the four-course system is taken, should be extended to seven or eight years at least, thereby favouring the grasses, which pay (if they do), in preference to the grain, which does not.

His lordship appends a list of seeds which he states he has found, after various trials at Holkham, to be best adapted for securing a pasture on poor soils for a period of not less than six years.

Subjoined are the quantities and varieties of seed per acre, the total cost at the prices given barely exceeding ${\text { I } 3 S_{2}:-}_{-}$

Semds for Temporary Pasture on Light Lands.

\begin{tabular}{|c|c|c|c|}
\hline $\begin{array}{l}\text { No, of } \\
\text { li). }\end{array}$ & Name. & Price per lb. & Price. \\
\hline 4 & Cocksfoot (Dactylis glomerata)............ & $\begin{array}{l}\text { s. d. } \\
\text { o I I }\end{array}$ & $\begin{array}{lc}\text { s. } & d_{8} \\
3 & 8\end{array}$ \\
\hline 2 & I'erennial ryegrass (Lolium perenne) ... & o $\quad 2 \frac{1}{2}$ & 05 \\
\hline 2 & Italian ryegrass (Lolium italicum) & o $3 \frac{1}{2}$ & \\
\hline I & Timothy (Phelum pratense) .............. & 06 & \\
\hline $\mathbf{r}$ & Tall oat grass (Avena elatior) ........... & 0 Io & o 10 \\
\hline$\frac{1}{1}$ & Golden oat grass (Avena flavescens)...... & 30 & ० 9 \\
\hline 2 & Mcadow fescue (Festuca pratensis) ...... & - $8 \frac{1}{2}$ & I 5 \\
\hline I & Hard fescue (Festuca duriuscula) ......... & & $\circ 7$ \\
\hline $\mathbf{I}$ & Tall fescue (Festuca elatior) ............... & & \\
\hline $\mathbf{I}_{2}^{1}$ & Alsike clover (Trifolium hyloridum) ...... & ० 9 & I $\quad \mathrm{I} \frac{1}{2}$ \\
\hline I & White clover (Trifolium repens) ....... & I 2 & \\
\hline$\frac{1}{4}$ & Yarrow (Achillea millefolium) .......... & 34 & 0 I0 \\
\hline 17 & & & $13 \quad 1 \frac{1}{2}$ \\
\hline
\end{tabular}

His lordship goes on to say: "It is very desirable that the pasture should not be too closely fed by sheep during the summer months of the first two or three years, and it is better when practicable to mow the seeds the first year after laying dowl. The ryegrasses insure a sufficiency of herbage during 
the first year or two before other grasses have established themselves, and the two oat grasses are included, as they have been found to be natural to the Holkham district."

So far as a five to six years' ley is concerned, we entirely concur with the practical remarks his lordship has made, and by way of comment upon his table of selected seeds we would add a few observations of our own.

We note that a prominence is given to meadow fescue, whilst foxtail, sheep's fescue, and dogstail are ignored. Italian ryegrass, a biennial, also has a place, the reason for which would be hard to understand were it not for his lordship's explanation; but when it is remembered how this grass exhausts the land, starves and 'smothers other seedlings, we rather doubt the wisdom of its insertion. Tall fescue we also think would be better omitted on account of its ergotty nature. The quantity of cocksfoot seems to us large, although, if the soil be very poor indeed, it would not perhaps be excessive.

The mixture we have found to answer best for somewhat similar lands is the following:-

\begin{tabular}{|c|c|c|}
\hline $\begin{array}{c}\text { No. of } \\
\text { lli. } \\
\end{array}$ & Name. & $\begin{array}{c}\text { Entimated No. } \\
\text { of germinating } \\
\text { seeds. }\end{array}$ \\
\hline 3 & Hard fescue (Festuca duriuscula) ............... & $I, 525,000$ \\
\hline 2 & Cocksfoot (Dactylis glomerata) ................... & 809,000 \\
\hline 2 & Meadow fescue (Festuca pratensis) ............... & 462,000 \\
\hline 2 & 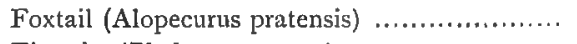 & 522,000 \\
\hline 2 & Timothy (Phelum pratense) ....................... & $2,500, \mathrm{COO}$ \\
\hline 2 & Perennial ryegrass (Lolium perenne) ............ & 420,000 \\
\hline 2 & Trefoil (Medicago lupulina) $\ldots . \ldots \ldots \ldots \ldots \ldots \ldots . . . . .$. & 620,000 \\
\hline $\mathbf{I}$ & Dogstail (Cynosurus cristatus) ....... & 795,000 \\
\hline I & Sweet vernal (Anthaxanthum odoratum)......... & 440,000 \\
\hline I & Tall oat grass (Avena elatior) $\quad \ldots \ldots \ldots \ldots \ldots \ldots$ & I 15,000 \\
\hline $\mathbf{I}$ & Iellow oat grass (Avena flavensis) .. & $840,0<0$ \\
\hline I & Alsike clover (Trifolium hybridum) ............... & 700,000 \\
\hline I & Perennial cow grass (Trifolium pretense perenne) & 200,000 \\
\hline 1 & White clover (Trifolium repens) $\ldots . \ldots \ldots \ldots \ldots . . .$. & 710,000 \\
\hline 22 & & $10,658,000$ \\
\hline
\end{tabular}


Ten millions is the orthodox quantity of germinating seeds per acre, and our mixture shows half a million over that amount. This is, we contend, an advantage, as the sower can cut out a few should he choose to do so, but under the ordinary conditions of our average seasons the extra quantity will not be found excessive.

We have omitted to append the prices of the seeds mentioned by us in the above mixture, because they vary enormously in accordance with the crop, season, and demand.

During February of 1896 , the Earl of Leicester very kindly conducted us personally over his Holkham farms, and thoroughly explained to us his system of an eleven-course shift. With his lordship's permission we will now place on record a few of the mental notes we made during that most interesting interview. His lordship drew our attention at the outset to the main object for which he was striving, namely, to make his poor light lands (the quality of which may be judged when we inform our readers they can only be rolled with a Cambridge drill roll, because if rolled with a flat roll they would be liable to blow), show a profit on his rent roll. At first, we must confess, we rather doubted the possibility of this, but before our visit came to an end we were convinced how eminently successful had proved the results of his lordship's efforts in this direction. The two main points which have influenced this success are as follows: I. The cutting down of the expenses to a minimum. 2. Farming in such a manner that the land fertilizes itself without the help of artificial dressings.

One astonishing fact was impressed upon us, that it mattered little to the success of the four following husbandry crops whether the land had been, during its seven years' rest, under herbage, cropped with natural or with artificial grasses, or whether the artificial grasses were free from or impregnated 
with weeds; any weeds, such as thistles, being kept under by hard grazing and the scythe.

Many years since a party of thoroughly practical agriculturists visited Holkham to inspect the experimental farms. In one field that had been allowed to lie waste as an experiment, and been fed for seven or more years, they could not find (even on close examination) a single patch of cultivated grasses. When this field was cultivated like the remainder of those which had enjoyed a seven years' rest, it gave precisely similar results. This is both astonishing and interesting, and there, doubtless, are many derclict lands in England that could be treated successfully on Lord Leicester's plan if they were properly taken in hand. Of course, it must not be forgotten that the feed from a field in such a state would be inferior to the feed of pastures sown with cultivated grasses.

Although Lord Leicester's system, so far, has been confined to light and poor land within the park walls (no small area), we see no reason why it should not be equally applicable to heavy or to any other kind of land. The courses are divided as follows :-

In the first course, the land is ploughed up as soon as convenient in the autumn, skimmers are used, and all is turned in and buried closely, so that decomposition may set in during the winter, and assist the increase of humus.

His lordship most strongly deprecates, under this system, the burning of quicks and olher rubbish, and it was rightly pointed out to us that the so doing destroys the humus (derived by burying), and leaves but the smallest return of potash. Burning weeds on the land was likened to burning the money in one's own pocket.

In the following spring the land is cross ploughed, care being taken to keep the plough just under the autumn work to cut the turfs into squares as is required. Governed by the state of the land, the season, and other circumstances, a 
grubber cultivator is used at intervals until late in June or July, when the vegetation will be found to have so far perished that it can be ploughed in. The land is then handled in the usual manner, and six pints per acre of rape seed is drilled in, I 8 in. apart. Having been duly horse-hoed, the green rape is fed off by hoggets (née tegs), and during the winter, corn, cake, or hay, is given in addition as may be thought desirable. It is then once more ploughed, which leaves it a good store of both humus and nitrogen for the next course.

The second course consists of oats, which poor land, treated as above mentioned, reproduces in very much larger quantities than it has before under the old system. The straw is found to be similarly affected. Upon the oat stubbles we visited weeds were astonishingly scarce.

The third course is commenced by treating the oat stubble in the same manner as is customary under the four-course shift, in preparing for roots. Ploughing, grubbing, and harrowing, destroying any seeds that may lie dormant in the land, and getting all in readiness for a crop of hardy common turnips drilled in on the flat in July. These are horse-hoed, cross-hoed with horse apparatus, and sometimes cut out by hand and singled, but this latter system of cutting out is rather the exception than the rule, the cost of labour being thereby materially increased. In walking over this course of turnips, which was being fed off by ewes and lambs, we noted, with some surprise, the total absence of twitch or any other weeds from the field.

For the fourth course the land, after the roots have bcen fed off, is ploughed and sown with barley. Here again we noted a divergence from the common practice; six pecks (one and a-half bushels) only per acre is drilled into this inferior land, instead of the larger quantity of from eight to ten pecks. The average crop during the season of 1895 (by no means a favourable one) showed over ten sacks per acre, which exceeded $32 \mathrm{~s}$. 
per imperial quarter on realisation. But the reader must remember that Holkham Park is only two miles, or thereabouts, from the sea, which would materially affect the quality of the barley, although the reason for this does not as yet appear to be clearly known.

With the fourth course of barley is sown his lordship's own mixture as set out above, varied slightly in accordance with circumstances.

Whilst discussing it, his lordship stated that clovers were of very little value to him in Holkham Park, and that trefoil was worse than valueless, as, when it did succeed, his sheep did not care for it, and, if forced to ent it, it disagreed with them. Cocksfoot he considered preferable; it does not grow too coarse, and the stock eat it freely, especially during the autumn and winter months. The ryegrasses produce a crop before most of the other grasses have established themselves, but they gradually diminish. In all cases he deprecated a too close feeding by sheep during the summer months of the first two or three years of any pasture, and stated that to mow where practicable the first year after laying down was by far the wisest method of farming.

We suggested that dogstail (Cy'nosurus cristatus) and sheep's fescue (Festuca ovina) might perhaps be added with advantage, but we were met with the uncontrovertible argument of expense, and that there would not be an equivalent return for the increased expenditure.

A "maiden set," constituting a fifth course, we found in excellent order, but thin at the bottom. This we were told would produce a good hay crop, with plenty of feed to follow.

Inspecting en route a last year's hay crop we found the aroma good, but the material decidedly coarse.

The sixth course, a second year's ley, covered the ground nicely, but in February one is not able to judge the grasses sufficiently to pass remarks of much value. Here it is 
explained to us that it will first be fed or mown as may be found convenient, fed hard in the early spring, and gently handled as the summer progresses, to keep out the sun, and avoid serious consequences from possible scorching. There is no objection to leaving some of the feed until the autumn, as later on the stock will gladly pick down what they have earlier ignored.

At the third set, the seventh course, we notice king twitch commencing to assert himself, which he seemed to do with greater ease as the pastures become older, and in one place (the eleventh course) he had fairly established supreme command.

The eighth, ninth, tenth, and eleventh courses are all pasture.

The cash returns from each field show that these lands under grass gradually decrease in value, and during the last three courses leave much to be desired if the seasons are at all unpropitious, but this is set off against the improved value when the lands again come under cultivation. Although the year of 1895 was considered by no means favourable, yet it was not looked upon in the light of a bad year, and if his lordship never experiences a worse he considers he will not have much to complain about.

This is contentment indeed, which our old proverb says "is worth more than a kingdom." We wish that all other agriculturists were only of the same opinion. 


\section{CHAPTER V.}

C.ITCH CROPS.

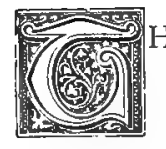

HESE crops are sown when and where the original crop wholly or partially fails, or the land is occupied during a portion of the season, or an unexpected demand for cattle food is probable-such as a failure of the root or hay crop, or excessive cheapness of stock.

Catch crops chiefly consist of white turnips, rape, mustard, Italıan ryegrass, common ryegrass, oats, or bere trifolium (to cut green), red suckling, and other mixtures, according to requirements.

Should the seed set fail in the spring too late for at sulssequent grain crop, catch crops should be arranged from rape or kale, either of which can be fed down at least twice during the summer and autumn, and yet be off the land in time for wheat sowing.

In place of wheat two crops of tares can be obtained; the first may be consumed in June, or early July, which gives plenty of time for ploughing and re-sowing a second crop before the close of the latter month, or the crop, when young, can be folded; in each case a second crop can be grown. If the crop be cut or fed off in June, it may be as well to sow a jumble of barley, oats, peas, tares, or buckwheat, which can be. consumed by soiling, or siloing; or rape, turnips, or mustard, 
as may be thought desirable; or a pulse crop, which latter would occupy the land the whole summer.

If it is desirable to farm for hay or feed, and in the spring it is found there are not sufficient autumn seeds alive, or that it is not desirable or convenient to plough up the ley, and the opportunity of sowing trifolium, red suckling, Italian ryegrass, or other late autumn seeds has been missed, the only choice apparently left is to drill in tares, although this course is seldom successful, as they are difficult to establish, and very attractive to rats, mice, and birds.

It is always advisable to consider catch crops in the autumn.

Italian ryegrass will bear very late sowing, especially during an open season, and it is safe to sow it quite into October; the land need not be ploughed, but it is desirable to bury this seed as much as, possible. Italian ryegrass is so prolific that a slovenly farmer who has a stubble he can do nothing with, in consequence of twitch and other weeds, sometimes sows Italian ryegrass, with or without a mixture of trifolium, and harrows all he can with a view of smothering the weeds, in which he is often successful.

Trifolium is good as a catch crop, but it must not be sown so late as Italian ryegrass; it is not advisable to sow it after September, and it does not require burying. We have known great success follow from simply throwing trifolium seed on a foul stubble, and leaving it to its own resources. It is also used for mending weak layers, as is red suckling, white clover, alsike, and trifolium, mixed with Italian ryegrass, all of which will form a good catch hay crop, but the mixture must be sown soon after harvest is over, every day's delay lessening the chance of success.

$\Lambda$ fter harvest it is a common custom in East Anglia for flockmasters to plough up a clean grain stubble and drill in three bushels of rye per acre to form a catch crop, in most cases using ten loads of farmyard manure per acre (a desirable 
plan) to help its growth, and prepare the land for the young turnips of the following year. This crop, during an average season, will be found ready for the ewes and lambs about the first week in April, but it is of comparatively little value at the end of the third week in the same month. Calculations should therefore be based on this knowledge, and only sufficient seed for a fortnight's consumption sown. Should there, however, be a prospect of a great scarcity of spring feed, so the grower must submit to feeding a scant crop, or take the risk of an open spring, sufficient seed for a month may be sown, and the flock turned in to feed the crop during the latter end of March.

On our farm we adopt the course we have quoted above. We manure well, and sow for a fortnight's consumption by the flock, and our turnip crop afterwards is almost always heavy. When the rye seed gives out we fill up the drill with tares and wheat, and sow an area of ground sufficiently large to produce another fortnight's feed.

Over the land which we have apportioned for the second fortuight we sow about $6 \mathrm{lb}$. to $8 \mathrm{lb}$. of trifolium per acre, the seedlings from which the young lambs, taking advantage of their special hurdles, carefully pick off before the fold gets on, and the feed is very advantageous to their growth.

Maize is now considerably used for catch crops, of this we have had but comparatively few years' experience, and our knowledge hardly extends beyond the observation that it is greatly liked by milch cows, and gives good results in the dairy. It must not be sown until quite late in May in consequence of possible frost, which is fatal. Most growers prefer to sow maize thickly, which causes it to become more leafy, prevents coarseness, and is a greater safeguard against the depredations of birds, rats, and other vermin. From a bushel to a bushel and a-half of maize, with a similar quantity of tares per acre, is the best quantity, in our opinion, to sow. 
We add the tares because both are uncertain crops, and, as the same weather is not suitable to each variety, the grower has alternate chances of success from the one or the other of the two crops. Maize prefers a hot, dry atmosphere, with occasional thunder showers; whilst, on the other hand, tares like as much rain as they can get, and seem quite indifferent to any wet or cold during the months of June or July. So, should the summer be hot, the maize will, comparatively speaking, smother the tares; if, on the contrary, the summer is wet and cold, the tares will obtain the upper hand; but unless good rains supervene soon after sowing, to give the seeds an opportunity of striking root, both crops will be a failure.

The crop arrives at maturity in accordance with which crop has the preponderance. If the tares, then in September; if the maize, then in October.

The crop should be taken off by the end of October, and the residue and the re-growings of early cuttings cleared by the flock in time to plough and prepare the land for wheat or other crops.

There appears to be some difference of opinion upon the best description of maize to sow. Some advocate the Black Sea European maize, commonly known as Danubian, whilst others are equally as warm upon the merits of the North American flat maize. For our part we think it makes little difference which is sown, and the only point upon which the buyer need be careful is to make inquiries as to the port of shipment. Maize shipped from Montreal, New York, or other northern ports is always preferable to that shipped from any of the southern ports of North or South America, or from Australia, or the Cape of Good Hope. So far as other maize is concerned, avoid that shipped from Egypt, India, or Morocco.

It seenis quite proverbial that a bad hay crop signifies a bad 
grain crop to follow. Therefore when this warning signal looms up before one, it is a matter for consideration and action, in order to avoid, if possible, a second failure.

One plan is to cover the hay stubble with a good coating of farmyard manure at Midsummer, which keeps out the sun, and produces a crop of sour herbage of little value, except to plough in during the autumn. If the farmer has time, he had better break up the land at once, and take his chance with a catch crop. Should it be a clover stubble, it should not be disturbed until it is ploughed in the autumn, because a week's rain will resuscitate it, and produce valuable herbage, and cause it to continue to collect nitrogen.

Assuming that it has been determined to try a catch crop, several courses are open, with more or less advantage in each case, according to the state of the land, the farm's requirements, and the season.

Many farmers plough in the flag with or without manure, and sow the crop without further delay, trouble, or expense, no matter whether they are sowing turnips, tares, buckwheat, rye, bere, rape, tares, or a selection. If an early hay crop has been secured, white turnips can be sown as late as the first week in August; but if the hay crop has been very late, then mustard is a last resource, as mustard is the quickest growing, the least able to resist an early frost, and the least valued of all catch crops. Any of the above-named crops can be fed off, soiled, or made into ensilage, or hay, as desired, or they can be ploughed in, which entirely depends upon the circumstances in each case.

Sometimes the land is in such a foul state that it is desirable to sow no crop at all, but to take advantage of the late summer and early autumn, and devote attention to the clcaning of the land.

Clean land, one can deal with as one pleases; foul land, one must deal with it as one iun. 


\section{CHAPTER VI.}

THE RECLAMATION OF BOGS AND SWAMPS.

$\mathrm{T}$ is so pleasant to the tread, so pleasing to the eye, to walk over a swamp on a fine June morning, that any attempt to convert it into a plain, even pasture marsh, would seem vandalism to the mere lover of simple nature. By so doing, the ever rustling sedges and rushes would be taken away, the waving cotton plants would be destroyed, the yellow irises, the golden marsh mallow, and the carpet of mauve bloomed cuckoo plants would all be obliterated from the landscape. These considerations were not taken into account in years gone by, when owners of swamps were able, with the assistance of capital, to carry their ideas into practice, and the "scaping" of snipe had perforce to give place to the lowing of cattle. Now that the wave of agricultural depression is on us, we find many instances where this order of things is reversed, and instead of swamps becoming marshes, many marshes are becoming swamps, because the pockets of their owners have been so bled by the times that they are powerless to help themselves.

It is an old English quotation that "hope springs eternal in the human breast," and although many of us may not have the necessary funds at our disposal to carry out our ideas at the present moment, that happy day may not be as far distant as we imagine, and, looking at the bright side of things only, 
we will consider what could be done in the way of improving low-lying marshes, swamps, and bogs.

The difficulties to be surmounted in the matter of this kind are, as a rule, considerable. The first step is a careful survey of the land proposed to be dealt with.

Regarding the reclamation of the East Anglian "flats" or "meal meshes," such as are to be observed round our coast line near Wells-next-the-Sea, we do not propose to treat. It would form a subject in itself, and would hardly come under our present heading. These flats were very aptly described by a writer in the Spectator (November I6th, I 895 ), as "The moorlands of the sea; unique, lovely, like nothing in nature but themselves, and their most general title is the least misleading." Our intention is to confine ourselves more particularly to inland swamps, and to give notes of our personal observation.

Having surveyed the land, the map is marked where it is considered practical to make walls, and to cut dykes or drainage ditches. In making walls it may be necessary to pile, or to cut a trench and "puddle in" with tenacious soil, as few walls are of effectual service unless a foundation of some kind is found or artificially constructed. In some cases it is advisable to avoid certain spots, or make a detour where the land that would be inclosed would probably not be worth the cost of inclosing. If the wall is made without touching a solid sub-soil the work may prove to be labour in vain where water is the boundary line, for when a storm arises and a heavy pressure is brought to bear upon the wall on a lee shore, the whole wall may in places lift and be washed away like a bunch of feathers. Where retentive soil cannot be found on which to place a foundation, an artificial one must be constructed, and a rib of good holding matter, such as chalk or clay, puddled into the centre of the wall; a row of willows is a good addition if planted near to the sides of the 
wall. Salt mud or ooze is one of the best materials for forming a wall, and in most cases it is neither difficult to obtain, nor to freight to the place wanted, without an unreasonable expenditure.

A ditch is almost invariably cut either on the inside or on the outside of the wall, which, in building operations not only assists as a roadway, but also helps to build the wall, the soil extracted being used for that purpose.

When wall building round some swamps on our farm we constructed two cheap and excellent "flats" (oblong flatbottomed boats), capable of carrying from five to ten tons each. We found them most useful afterwards when repairing the walls, and in ferrying hay, osiers, and litter. One we have converted into a houseboat, and it has been used for years by workmen, keepers, and others, and we have often been glad to avail ourselves of its shelter when caught in sudden storms whilst shooting.

It is impossible for us to give anything but the most general outline of the subject matter which we are discussing, because each case must necessarily depend upon its own individual circumstances.

Having completed the walls and banks satisfactorily, the next step is to cut drains and dykes, gradually enlarging them the nearer they approach their main outlet; in the case of the former where they join the dykes, in the case of the latter where they join main dykes, or the opening to a sluice, or drainage mill of wind or steam power. The vast improvements that have been made during the past few years in pumps and turbines for drainage purposes have greatly facilitated the reclamation of swampy land, and suitable machinery can be obtained for draining almost any land at a minimum of cost to what was the case a few years ago. In selecting the pump crr rather on the side of getting one larger than is required than smaller; the extra outlay will never be 
regretted. Perhaps it is unnecessary to add that the drains and dykes must always be kept well cleared of all weeds and water growth, so the water has easy flow, which is the keynote of success in drainage.

The first effect noticeable in swamp reclamation is that the natural bog vegetation becomes thinner and more stunted in growth, moss begins to appear in large quantities, and a peculiar grass (somewhat resembling twitch grass, but blue in colour) puts in an appearance. About May zoth mow down as closely as possible all vegetation, which bleeds, weakens, and destroys the watcr-loving plants. In a short time little will be seen upon the marsh except a few straggling black rushes and the aforesaid moss and blue grass, which nothing will eat. By diligently moulding and sowing renovating seeds some useful grasses will soon establish themselves.

In the selection of renovating seeds do not forget the nature of the soil used for moulding, the general nature and surroundings of the land proposed to be sown, and make allowances accordingly. Observe those seeds which thrive best, and profit by experiments.

Of the heavy seeds we have derived most benefit from alsike, red suckling, white clover, and perennial cow grass. In grasses the coarser are preferable to the finer; fiorin and cocksfoot are better than either of the hard, tall, or meadow fescues. The poas are not so suitable, except Poa aquatica, which is most serviceable if it can be obtained.

At this stage the marsh (if it can be called a marsh) cannot be punished too much by stock feeding and jamming about on it. I) Juring the winter moulding is continued, and when the frosty weather comes cart on not less than forty loads per acre of heavy soil. In the spring, if practicable, fold fattening sheep upon the marsh, feeding them with artıficial foods, hay and turnips, etc.; follow with renovating seeds, and the transformation will be more rapid and lasting. 
Treatment such as we have described forms a kind of crust which seems to give the better grasses good root hold, and in moulding, any soil will do, even if only sand; but the richer and heavier it is the better.

When the reclamation of swampy land is under consideration, it should be remembered that inferior marsh hay is only worth from 5os. to 7os. per ton, whilst good litter commands from 2os. to 30 s. per ton; therefore, unless the improvements are thoroughly and efficiently carried out, they had better be left alone, as it would be a fatal mistake to destroy a quantity of good litter in order to secure a miserable hay crop, or perhaps no hay at all.

The great advantage to be looked for by the reclaimer is the feed he hopes to obtain, because; although reclaimed bogs will not produce inordinately on a wet and cold summer, when hay and feed is so plentiful and store cattle so dear it does not pay to buy them, and often spring purchases turn out not to be worth their original cost in the autumn, yet during a hot, dry season, when both hay and fodder are scarce, and complaints are rife from all sides of starving cattle and burnt-up pastures, these reclaimed bogs and swamps (favoured by the sun's rays) produce feed of an abnormally fine quality, and in quantity what is truly astonishing.

Most of the marsh lands of East Anglia, where the rivers are salt or brackish from the tide, have a sub-soil of alluvial clay, which produces the finest pasture, and will fatten cattle in summer without artificial assistance. This sub-soil is also excellent for banking, wall making, and of late years has been. used considerably for the purpose of manufacturing bricks. In some places the turf is but a thin veneer to the bog underneath, and the nearer one approaches to the uplands the more will the depth of the bog prevail. Near to the uplands peat is the more predominant sub-soil, and in cutting dykes it is a wise course to use the excavations for moulding 
the marshes near the river where the sub-soil of alluvial clay abounds, and vice versâ. In one case within our recollection we adopted this experiment of moulding a marsh near the river with the peaty excavations of some dykes which we cut from a bog under the upland, folding sheep on it, and, afterwards renovating with seeds; in one season the value of the land was doubled. The first sign of improvement in reclaiming bogs and swamps will be the disappearance of the black rush (Schanus nigricans) and the appearance of the tussock rush (Caren paniculata).

Botanists assert that tussock rushes, which are common enough with us, prefer spongy bogs to better-drained marshes; but, with due respect, we venture to differ from them, because, although their presence is common enough upon the edges and drier parts of spongy bogs, our experience leads us to believe that these rushes require good land, which has been partially drained, and where the ordinary bog rush does not thrive so well. This opinion is confirmed by the fact that, as soon as the bogs are improved and the drainage is got on with, the tussock rush appears. A similar experience will be met with when a moist pasture has been neglected and its drains allowed to grow up. The tussock grass, therefore, becomes, if we may so express it, both the harbinger of good and of evil. We are glad to see it on the lands we are reclaiming, but we regret its reappcarance on the lands we have reclaimed, which, by reason of our negligence or our want of means, have been neglected. For the removal of tussock grass the mattock must be freely handled; its presence denotes insufficient drainage and a surplus of water.

The sedges and rushes common to swamps forms such a numerous family, and are so closely allied, that it would be injudicious on our part to attempt to deal with them individually. To give an example, we refer to the grasses (Graminea) and the sedges (Cyperacea), which differ from 
ordinary flowering 'plants by having their stems and pistils inclosed in husks; they exist in hundreds of varieties.

Next in prominence to the tussock grass we consider the black bog rush (Schcenus nigricans), to which we have already alluded. This rush only attains a height of one or two feet, and it can easily be distinguished by its short heads of black glumes, its tough and fibrous roots, which consolidate the surface of the swamp, upon which they grow to the exclusion of almost all other plants.

Those who are inexperienced think sedges, rushes, and water grasses useless, except for litter, but such is far from the fact.

The giant bulrush (Scirpus lacustris) is largely used in the manufacture of horse collars, especially those employed for breaking colts and horses with tender shoulders. Coopers use them for barrel making, and of late years they have been in great demand by furniture manufacturers; but in this latter industry French competition is making sad havoc. At Norwich, the centre of Broadland, ornamental rush work of a light description finds a ready sale, and many a poor marshman is able to add to his earnings by supplying the rushes which are used; but here even the influence of foreign competition is felt.

The harvesting of bulrushes might at first sight seem simple and easy; it is not so. To obtain a good article which will find a ready market they must be most skilfully and deftly manipulated when first cut in June, otherwise they lose their beautiful glaucous colour, which is their most necessary essential.

Certain reeds, sedges, and grasses are extensively used for thatching houses, cottages, and barns, making sheds and for bedding for cattle. The reed (Phragmites communis), which is common with us, is used more for thatching than for anything else. It is cut in November before it has lost the 
leaf. When wanted by plasterers for foundations for walls and ccilings, it is not harvested until December, by which time the winds and rain have taken off the leaves, and only the clean stalks remain, ornamented by their grey flowered spikes.

For decorative purposes in ladies' boudoirs, halls, or rooms, they are gathered during the first week in October, and are set in water for a few days in order to develop their heads of light cotton wool-like bloom, which they will retain for months if not exposed to the wind: For this purpose also the stately bulrush (Typha latifolia), both lesser and greater, is in good demand, as are many more of our beautiful water grasses, which are dried and dyed with a variety of colours.

The roots of many of these water plants are edible; they contain much nutriment and chemical compounds, but we have not heard of their being used for food in this part of the country, although we read they are much esteemed in Iceland and elsewhere. 


\title{
CHAPTER VII.
}

\author{
HAYMAKING.
}

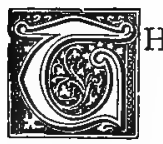

HIS industry is conducted in such a variety of circumstances and conditions, and the common methods of haymaking are so generally known, that it seems superfluous for us to discuss it; but were we not to do so, our work would be like a chain, a link of which was missing.

The most important point to be observed is to fix upon the right time for the cutting of the crop. 'There is no fixed rule for this, everything depending on the judgment and experience of the haymaker.

As will have been gathered from our previous notes, some grasses make the best hay when nearly ready to shed their seeds, but the majority are best about, or sometime after, tlowering time, and, as in permanent pastures, flowering commences early in May, continuing until August, even later, the difficulty of calculating the exact value of the many varieties and hitting upon a medium for cutting is apparent. If any doubts exist in the mind, it is far better to err on the side of cutting too soon rather than too late. It may be true that the early-cut grass wastes more than grass cut later, but the quality of the hay is better, and the second crop will be stronger; also, in a late cuttiug the early grass will be greatly weakened by seeding, and if the pastures be cut year 
after year many of them will be killed, and, although you may feed sharply and dress the pastures with mould afterwards, it will not counteract the harm that has accrued to them by procrastination.

The average loss of weight in drying grass to hay amounts to about one quarter of the amount dried. Should the hay be an artificial crop of alternate husbandry (clover or trefoil mixture, for instance), it is not advisable to touch the hay until it is sufficiently made to cock or carry on the same day, and the amount of bad weather this grass will stand without serious deterioration, so long as it remains unmoved, is really surprising. Should this hay be caught in a shower, a beautiful aroma will arise therefrom; but experience tells us that the greater this delightful aroma the worse will the quality of the hay become. Upon the slightest sign of approaching rain this class of hay should instantly be cocked; the cocks being sized in accordance with its forwardness and dryness.

If the hay is cocked in good order the cocks may be made very large, and they may be left undisturbed for at least two days, when it will gather a little heat. The cocks may then be thrown out to receive a couple of hours' sunshine, after which they can be put in readiness for the carter, thus causing the first fomentation when on the cock, and checking. the second heat until the hay is stacked, which is best for good hay.

Trifolium (Trifolium incarnatum) should be cut as soon as it begins to show colour, or it will become sticky and coarse; besides, the longer it stands the more difficult its seed heads will be to deal with, they being at all times difficult to dry; and, if numerous, the hay will require an extra amount of attention, or the stack will heat in a manner not only deleterious to the hay but alarming to the farmer.

Lucerne, sainfoin, tares, peas, or lupins, if made into hay, must also be treated in a manner similar to what we have 
before described. These plants are wont to lose their leares. during the process of drying, and must therefore be treated in locks.

These locks of hay are constantly added to, and made larger as the condition of the crop improves, until they grow into good-sized haycocks; but unless the most diligent care and attention is given, and the hay is turned as seldom as possible, a great deal of the leaf-the most valuable part of the plant--is lost. Should the season be wet, these plants are harder to convert into hay than an ordinary crop, but a period of fine weather must not be allowed to pass without advantage being taken of it, although the crop may not be quite ripe, or the maker quite ready to begin to work. Any other work on the farm should be postponed in favour of this class of haymaking.

Management of perennial pasture hay is quite different from what we have before mentioned, and the nearer we come to. London the better, apparently, is haymaking understood. The grass is put into small cocks the first day it is cut, in order that the dew may not deteriorate its quality. Unless. actually raining, it is thrown out again every morning, and recocked in the evening the cocks are made larger and larger as the hay becomes dryer. When sufficiently made it is carted to the rick, which is covered by canvas, corrugated iron, or other means, and the green colour is retained Only a small quantity is dealt with at a time, and the stack being some time in making continues to settle gradually, thus a vast bulk is stored.

In rural districts further moved from the great markets, hay is spread as soon as it is cut; the next day it is turned by a machine, and is generally found sufficiently made to cock. It is then drawn into rows by a strong tooth horse rake, and cocked in the ordinary manner.

In stacking, if the hay, on account of the weather, is 
over-made, a wide stack is desirable; but if the hay has been rapidly made, a long, narrow-shaped rick is better, as it is desirable to generate a gentle heat, and by this process convert the starch in the hay into sugar; if the heating be too strong, the sugar will be converted into acetic acid. On the completion of each course, a little salt may be sprinkled over the stack, but this must not be overdone. On some estates where large areas have to be dealt with, a framework is used, which is made something like a gate, having vertical bars with ropes fixed at each end, in the form of a bridle, by means of which horses are attached. This framework is used to draw up the rows of the hay until a large cock of five to seven hundredweight is formed, which, by reason of the manner of making, will be found to be drawn so tightly together and to be so compressed, that it can be left in the field for a week or more with impunity.

Should bad weather set in after the hay has been cocked, the uppermost lock of hay or the caps to the cock should be removed and re-adjusted without interfering with the body" of the cock, except by turning the solid mass quite over, which prevents the bottom hay from becoming mouldy or unsweet, whilst the process can be attended to at any time of the day when it is not actually raining. In such weather, and when a favourable opportunity uccurs, the cocks should be thrown out and aired before stacking.

Having selected the ground where it is intended to raise one's stacks, some little consideration should be shown for making the stack bottom. A free access of air must be allowed, so that it can pass between the stack and the ground. Iron appliances are often used, but where expense is a consideration, logs and trees will be found almost, if not quite, as good, and they will last for years. IVe deprecate the use of straw or litter, because it becomes tightly compressed, thus encouraging capillary attraction, which moulds and spoils a 
considerable portion of the hay. We are more in favour of the use of the trimmings from fences, hedges, and ditches. Faggots make an excellent stack bottom, but it must not be. forgotten that they only last some two years.

In building the stack much more pasture hay can be dealt with on the same sized stack bottom than hay made from stover or alternate grasses, and the longer one takes in making the stack the better the result is likely to be. Three weeks to a month is about the limit, but the stack should be covered at night. In building stacks always keep the middle full. Avoid unloading on the same side, and do not permit the man who receives the hay to stand too much on the same place. Avoid jamming on the stack, unless some more hay is immediately put upon the jammed place, and as the stack progresses have the sides pulled with a rake, in order to get the stack solid and into a good shape.

The top of the stack seldom producing good quality hay, inferior or coarse stuff is collected to top up with, and the roof may be made as steep as can be, as it will be sure to settle down lower than one desires by the time the thatcher comes. round to finish it off. The stack should not be thatched until the heat is well on the wane, because it has a tendency to prevent heat escaping, which is most undesirable, and apt to generate mould.

Should you desire to keep a few extra loads of hay ready to fill in the middle of the stack in case bad weather causesunexpected delay, it is advisable to cover this extra hay with a thick coat of rough litter, in place of a cloth, and should thisextra hay be stored in a barn, be sure to always keep a.1 the doors and wickets open night and day, so that it may generate its heat without undue moulding.

Lastly, we would impress upon our readers that every drop of rain carted with hay causes mould, and hay had better be left lying about for months, than got up in a condition 
78 PRACTICAL NOTES ON GRASSES AND GRASS GROWING.

likely to mould, as mouldy hay does incalculable harm to both horses and cattle; whereas, dry hay, whatever its quality, can always be used, and, if necessary, an artificial flavour can be given to it, or it can be cut up with ensilage or other foods. 


\section{CHAPTER VIII.}

FNSILAGE AND TEMPORARY SILOS.

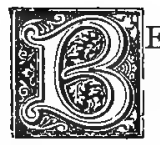

EFORE discussing silos or ensilage, or rather, the particular experiment in connection with them which we have any faith in, we would say a word or two by way of preliminary, and to show why we have introduced the subject under our present heading.

That an economic silo is an advantage to the grass-grower we affirm without hesitation, and we now proceed to give our reasons.

It is a common fallacy to suppose that judicious mowing weakens pastures. We have gone fully into this under a preceding sub-heading, and we trust we shall be forgiven if we in any way repeat our remarks when we say that in closing layers for hay the bulk of the herbage is not mown until it is ripe; now most grasses are not ripe for hay until they are in full blossom, and some not until they have even further developed. Taking it as a fact that grass which is allowed to remain untouched until it has blossomed is weakened (sometimes to death when the seedling is young), and that earlier grasses, such as foxtail, flower as early as April or May, and that others are not so far advanced before August, it follows that closing a layer for hay undoubtedly weakens the plants. It also follows that haysel, during June or July, is injurious to, and weakens a vast percentage of, the grasses; and when (for convenience 
sake, perhaps) haysel is postponed to a later date than this, the injury to the sets becomes the more aggravated. We regret that we are in a position to record a recent and striking illustration which we are not likely to forget, because the mistake was ours and we had to bear the loss.

In the year 1893 one of the best fields on our farm was fed late, and afterwards closed. The summer was so dry that the hay never grew sufficiently long for us to cut, and in consequence we did not feed it until after harvest. In 1894 we fed it, and found it had sadly deteriorated. Unfortunately we again fed it late in 1895 , closing it for hay afterwards. In July wet weather set in, followed by drought (as in 1893), which caused a most uneven growth, and, forcing weather bringing on harvest earlier than we had anticipated, we again neglected the pasture until harvest was over, when we mowed the coarser spots and found this once fine meadow practically ruined.

We fancy we can hear several of our friends saying, "Physician, heal thyself." Our only answer is "Humanum est errave."

Some places on the field have become intensely coarse, others will grow little or nothing, and we are now concentrating all our efforts to bring it back again to its former state.

Closing a ley for ensilage making is quite different to closing it for hay, because it is the soft, unripe, and half-matured grass, that is best adapted for this purpose; hence the would-be ensilage maker can cut his grass early and persistently, thereby strengthening and nursing his best grasses, and giving them every chance of thriving and doing well, at the same time weakening the coarser varieties to their subsequent advantage, and so bleeding the weeds that they are rendcred innocuous for many a day to come.

Not only grasses, but clovers, lucernes, tares, oats, maizein fact, almost any kind of herbage-are suitable for being. converted into ensilage. 
When the silo is being filled, the mowers or machine should be started earlier than the carters, in order that whatever is cut may be packed away without any undue delay.

In summer weather we advocate the cutters should commence at $4 \mathrm{a} . \mathrm{m}$., and the carters should follow two hours later. The produce should be carted to the silo at once.

In the autumn, when the atmosphere is moister, such precipitation is not necessary. Ensilage is simply, if we may so express it, "canned grass," and, in making, the whole secret is to pack it in such a manner that all air is excluded, and generated heat kept down to a minimum. It is an elementary fact that grass, as soon as it is cut, begins to change its nature by reason of the action of the air, and the drier the air the more rapid is this change effected. Therefore it is best to select foggy, or still damp weather, for the time to fill one's silo, as then it is not necessary to exercise undue haste.

It is immaterial how wet the herbage may be when used for packing in the silo. If dry, it is liable to generate stronger heat, and is not so easily compressed.

We would say a word regarding the quality of the material used for ensilage. We have said that almost anything is sutable for this purpose. So far as that remark goes it is true; 'but it must be remembered that the better the article ussed, the better the ensilage produced; this, we believe we are right in stating, has now become an admitted fact by all who have experimented in silos.

As to the use to which ensilage may be put, remembering the many opposite and varying views which are almost always expressed on this subject whenever it comes up for discussion, we shall confine ourselves to our own experience, leaving the reader to draw conclusions.

We like ensilage less for horses than any other kind of stock. We find store cattle immensely fond-in fact, they are too fond of it; and like "Oliver Twist," however much you 
give them, "they ask for mure." If ensilage is mixed with long hay, the store cattle will spoil half the hay in trying to extract the ensilage from it. We use ensilage with success with all our cattle, cutting it into chaff and mixing with hay. When ensilage is plentiful we give the horses a little, but when scarce it all goes to the in-milk cows and to the ewes. We find it better for in-milk animals than for others; and when we are short, the cow-keeper often has his difference (or as they say in these parts, "exchanges a few words") with the shepherd, when it comes to the division of the provender.

Ensilage is good for milch cows, but it must be given in such a manner that the milk does not absorb its aroma. All ensilage feeding must be conducted with care and prudence.

With strong pastures and plenty of sun we make all the hay we can; but when we find our pastures are weak, and we experience wet summers, then we obtain most benefit from our silos. During 1894 we were compelled to make so much ensilage that we had quite sufficient to carry us through 1895 , when, fortunately, the season favoured our haysel.

Turning our attention to silos, we have noted how thousands of pounds have been spent experimenting upon them and upon the manufacture of ensilage, and that thousands of lines have been written upon the results obtained. That these experiments have not been crowned with success is generally known, to which the many abandoned and disused buildings unfortunately testify.

In face of this it may be thought presumptuous, or even rash, on our part to approach such a subject; but it was wisely laid down by the ancients, "Listen to every man, there may be something to be learnt; if you only listen no harm can come." We place before the reader the conclusions we have arrived at from practical experience of many years of study and of observation; we do not ask him to take our advice, but 
if we can be of any assistance to him, the knowledge that we have done so will be of itself a sufficient reward.

During the past ten years we have watched with interest the development of this question of silos and ensilage, and we have to the best of our ability endeavoured to reap a practical advantage from that observation. IVe have investigated the various systems from time to time introduced on farms and estates where no small sums have been invested on more or less elaborate methods of ensilage making. With all costly appliances we have been dissatisfied. There has always been some great drawback, generally the item of the $£$ s. d., and we have never been convinced that interest has been secured on the capital invested. In this desponding frame of mind we had abandoned all idea of turning silos to practical account, when we heard of yet another plan, the originator of which was most hopeful of success, and enthusiastic in the carrying out of his scheme. With little expectation we waited our opportunity and visited him. He received us with welcome, the volubility with which he propounded the pros and cons of his new-found joy amused us, such was no new experience, and we had no faith whatever in his argument. But he was a most persistent advocate, and at last he awakened our almost dormant interest. We proceeded to the scene of his operations, and we were astonished.

The idea was simple, inexpensive, and efficient.

There was no building, no plant, no machinery. $\Lambda$ temporary silo was before us which answered all requirements, with a further advantage - there was very little waste.

At first sight we thought we were gazing upon an ordinary "muck-heap," but a closer observation undeceived us. It was made as follows :-

A plot of ground had been selected where the water had a fall, and was easily drained away. The sub-soil was sand and gravel, and the expressed juices drained away spontaneously 
and automatically. A trench, about thirty feet long by fifteem feet wide, had been cut from a small hummuck in the stackyard, the bed levelled, and the grass carted there, and deposited in the same manner that a manure heap is formed. Each load had followed the other in rapid succession, and the horses had drawn the tumbrils quite on to the heap before discharging, and had been driven down from the opposite end, thus assisting to compress the deposit, and preventing undue heating. The edges and sides had been rammed or otherwise compressed as the herbage had becn deposited, and until the desired amount of grass had been accumulated. After this a foot or so had been cut from the sides, where they rose above the level of the ground, and the trimmings packed on the top of the heap, which in turn had been topped by a good layer of earth. No mould had been placed within a foot or so of either ends or sides. About five feet had been cut from each end, turned up, and both ends and sides rammed well home towards the centre of the heap. A drainage trench had been dug all round, the excavated soil being thrown on to the top, and the top had been levelled and rammed down hard. The quantity of earth on the top was sufficient to entirely exclude all air. The greater the weight of earth on the top the less will heating' occur, and the better will be the ensilage. To keep off the heavy rains, sheets of corrugated iron had been employed. Such was the silo which was presented to us.

'lo ascertain its practicability in use we visited another of our friend's silos on the same farm. This had been opened, and was half used. We found no waste either at the top or at the bottom, but there had been a little at the sides and at the ends, which seemed to depend in some measure upon the amount of care taken during the formation of the heap. The moisture is mostly squeezed out at the sides and ends, hence the advantage of the trenches before mentioned, and the reason of the waste. 
The silo we have described was of sufficient capacity to take as much herbage as could reasonably be cut, carted, packed, and finished off during the course of a week upon the farm we visited, which was a small one of about 350 acres.

Should it be desired to make one of these silos upon level ground, where the advantage of a sand or gravel sub-soil cannot be found, it is necessary to sink cross rows of drain pipes a few inches below the surface of the levelled bed, and to place over them a quantity of porous soil sufficient to exclude all air. It can then be made in the same manner as the one we have described.

That we profited by the visit, is answered by the fact that we have had resource to this temporary and inexpensive method of ensilage manufacture year after year, to our advantage and satisfaction. 


\title{
CHAPTER IX.
}

\author{
CLOVERS.
}

Common Rel Clover (Trifolizm pratente, Limn.). Single-cut Cow Grass, or Perennial Rerl Clover (Trifolizm pratense pereme, Sutt.). ZigZag Clover (Trifolizm meaium, Huldson). Woodland Cow Clover (Trifolium pratense, var. Sylvestre, Syme).

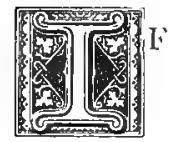

asked, "What is peremnial cow grass?" few farmers would venture to reply; if they did so their answers would be evasive or qualified.

We have searched the authorities from Sinclair in 1816 , and, as a result, we are induced to state our deductions, in the hope that others will follow in our footsteps, and thus further light may be thrown upon a most interesting question.

We would convey our warmest thanks to many of our friends who have written us in reference to this involved problem, especially to Mr. Martin Sutton, from whom we have received valuable information; his remarks upon cow grass, which the reader will find at the end of this chapter, should prove of the greatest interest and value to all.

Although seven years ago we wcre somewhat opposed to his argument, we have since been converted, which result has been partly brought about by practical experiments and observations of our own. 
As the main drift of the present chapter is to endeavour to solve the, as yet, undiscovered origin of the cultivated perennial cow grass, we have thought it advisable to first touch upon the plants which are undoubtedly closely allied to it, and afterwards give in extenso the last letter we received from $\mathrm{Mr}$. Martin Sutton, which throws considerable light upon the question.

The order in which we propose to deal with the grasses is as follows :-

Common Red Clover; Single-cut Cow Grass, or Perennial Red Clover; Zig-Zag Clover; and Woodland Cow Clover.

\section{Common Red Clover (Trifolium pratense, Linn).}

So rapidly and continuously does this plant grow, that any practical man gives it preference, wherever the soil will suit it. It rarely thrives on the same land more than once in eight years, and if allowed to stand over dies off partially or entirely during the second year, except perhaps when a dry season or other circumstances have made the first year's crop a very short one; therefore, one cannot expect to obtain more than a crop and a half in two years from land most favourable to its requirements.

Should the crop prove a failure during its first season, a fair crop may be expected during the second season, but seldom vice vers $\hat{a}$. This is accounted for by reason of its nature to exhaust certain elements of the soil, notably potash, whilst its enemy, the eel worm, soon destroys it, where it is young and shows signs of flagging (in the same manner that fluke destroys sheep); therefore it is always as well, when one entertains a doubt, to sow trefoil, alsike, or white clover with it.

We consider I $2 \mathrm{lb}$. per acre a sufficient amount of seed to sow where the land has been worked up into a good seed bed. 
In selecting red clover greater judgment is required than in the selection of almost ąny other seeds; there are so many different strains, it is grown over so large an area, under such a variety of circumstances, and unless the buyer knows the locality from the samples offered to him he may find himself landed with seeds which are utterly unsuitable to the land for which they are required.

Seeds imported from warm countries, as the South of France, Italy, America, and sometimes those from the IVest of England, are not to be recommended; whilst those from Holland, Belgium, parts of Germany, and Russia, are as hardy as the seeds grown in East Anglia, though often so full of weeds as to need an exceptional amount of care in cleaningUndoubtedly the finest samples in the world are those produced in East Anglia.

All samples of clover seed should be closely examined, in order to ascertain if they are free from weeds. Plantain (Plantago lanceolata) is one of the weeds from which red clover suffers most ; its seed is easily recognisable by its shape, which somewhat resembles a date stone. "Wild carrot" is another weed which must be remembered, its seed is covered over with innumerable little spikes; if the simile is a good one, we would compare the seed kernel to a minute hedgehog when curled up. When the seeds have been extracted from the pod, neither of the weeds we have above referred to can easily be separated from the clover, but if handled beforehand they can be taken from the bulk by the assistance of a windle and $\mathbf{a}$ coarse sieve. 'The clover seed in the pod is blown away from under the sieve, whilst the plantain and carrot-like seed fall straight to the ground.

Dodder (Cuscuta trifolii), to which we have before referred, can also be entirely removed by careful sifting, and the farmer should never grudge his seed merchant charging him a few shillings extra per bushel if the sample offered to him has been 
thoroughly sifted and cleaned, as few growers deliver the seed fit to sow.

All American clover must be accepted with great caution. The country is so large that it is hardly possible for the buyer to ascertain the locality, or even State, where it was grown, which to the English sower often makes a considerable difference. Our experience tells us that most of this seed produces a narrow-leaved variety, weak as seedlings, and weak in its subsequent growth; whilst the crop is rarely as large as that of its broad-leaved cousin.

Dutch seed is mostly good, as also may be said of North German, Polish, and Belgian, but all are liable to be full of weed seeds. Russia is developing a growth of first-class clover almost equal to the best English samples. The seed from New Zealand can hardly be equalled; this latter country is a comparatively new source of supply.

The worst seeds come from Italy and the south of France.

It does not appear to be generally known that ordinary Suffolk cow grass is merely a good stock of broad-leaved clover.

Some twenty years ago Messrs. Sutton and Sons, of Reading, introduced a new variety of clover. It has stood the test of the twenty seasons which have elapsed since then, and faithfully carries out what was promised of it, one point being that it would succeed fairly upon clover-sick land. From our observation of this variety, its seeds do not appear to be all alike. We have noticed that, if attacked by eel worm, portions only of the ley suffer, and it is clearly distinct from clover in that it has a more vigorous growth, and from perennial cow grass in that it comes for a second and even a third cut. The fact of its being so succulent causes the seed to be very difficult to harvest; indeed, in a wet autumn it is next to impossible to secure it at all, which accounts for the much higher price it commands over clover. 
Red clover is naturally a heavy land plant, and is said to be indigenous to every country in Europe, except Greece. During a droughty season, on very light soil, it seems to dry up altogether. It seldom dies, and when showery weather sets in it revives in a most astonishing manner; but, sown with perennial ryegrass, it forms the keystone of "one year's ley," The seed weighs $6_{4} \mathrm{lb}$. to $6_{5} \mathrm{lb}$. per imperial bushel, and each pound should contain about 225,000 germinating seeds.

\section{Single-cut Cow Grass, or Perennial Red Clover:}

(Trifolium pratense prerenne, Sutt.).

This grass derives its name from the fact that it is customary to feed it until the middle of the month of May, when it is shut up to produce a crop for the scythe, which is an exceptionally heavy one, and one which exbausts it entirely for the season.

Whatever one says concerning this plant is generally contradicted by someone else. For instance, many argue it is known by its hollow stalk, whilst others affirm the stalk is solid.. In this, both appear to be right as well as wrong, because when it first throws its flower the stalk is solid, and, as the blossom. develops, it becomes hollow. Many other instances we could quote, but refrain from doing so as we consider one sufficient.

From a superficial examination it may be thought identical with common red clover; but a close inspection, in the earlier stages of its growth, shows the stems to be slightly hairy and of a ruddier hue, while its leaves are more pointed.

The flower is generally a dark red, and the haulm often grows a foot higher than red clover; but the peculiarity of the plant, which is a great recommendation for soiling purposes, is that, instead of turning pithy and insipid immediately it comes. to maturity, it can be left for a fortnight or three weeks later, and yct be palatable for stock when cut green and carried 
into the byres, at a time when red clover is long gone past, and it thus.fills up a gap between the first and second cuttings of broad clover, when green meat is so greatly needed on the farm.

We do not say that cattle would prefer this cow grass to clover if the latter was available at the same time in an equally succulent condition; for if man mistakes the two varieties, stock will not, and, on a field sown half with each, the clover, while succulent, will be closely fed off before any attention is paid to the cow grass. But, after all, the chief value of true. single-cut cow grass is its permanent character, either when sown with permanent grasses or when sown alone on poor clays. and cold uplands, to remain down like sainfoin for three or five years. Its long tap-root penetrating deeply makes it, to a great extent, independent of the surface soil; and this is the true secret of its succeeding where broad red clover, with its fibrous root, cannot be grown at all, or only at long intervals.

It must not be confused with what is known as Suffolk cow grass, and which we have before mentioned. Suffolk cow grass is not perennial, nor will it stand year after year, or resist the attacks of the eel worm like perennial cow grass.

It is no wonder that botanists and others, who have to deal only with small plots grown in prepared soil, find a difficulty in appreciating the capabilities of the Trifolium pratense perenne under ordinary agricultural conditions.

A year or so ago we planted a dozen rows of this and common red clover, alternately in our garden, which puzzled all to whom we showed them, and who were so sure of their ability to distinguish the difference between the two varieties. Had the area been larger, and the locality more open, as on a cold upland pasture, there would have been no difficulty.

In a four-course rotation on good land no one would sow cow grass where red clover will thrive, red clover hay having. a higher market value, and a clover ley being a far better preparation for wheat. 
Cow grass seed is worth from 20 to 25 per cent. more than clover seed; but this fact is accounted for by its scarceness 11 comparison.

As the seed is indistinguishable from that of red clover, the greatest caution is required in purchasing it, and, as a rule, it is only sold with the name of the man who has actually grown it as a guarantee of its genuineness.

Occasionally we get samples of so-called cow grass seed from abroad; but, as one can never rely upon their being true, they are not recommendable.

The seed weighs about $6_{5}$ lb. per imperial bushel, with a germinating power of about 220,000 per pound; 20 lb. per acre is the quantity usually sown.

\section{Zig-Zag Clover (Trifolium medium, Hudson).}

This plant derives its name from its peculiar zig-zag growth.

It is chiefly found on dry banks, roadsides, or waste places, whilst its bright, crimson bloom, and dark green pointed leaves cause it to be easily distinguishable from the common red, the perennial, or any other clover.

Its seed pods are also of a peculiar shape, they are oblong in form, sometimes contain two seeds, and open at the side; whereas the pod of the allied species and varieties of this genus are shaped more like a pear, they open at the top, and contain in each one seed only.

Zig-zag clover is a deep rooted and very coarse growing plant, in which respect it surpasses all other clovers. Often have we seen its showy blossoms peeping out from and overtopping the bushes on odd bits of waste land. In flavour it is bitter, which prejudices stock against taking a second mouthful of its foliage, unless sorely pressed by hunger, or want of something better.

Not only does its tap-root run far down into the soil, but 
sometimes from this basis it branches out considerably. Fortunately it seems to have an aversion for open ground, and is seldom, if ever, found on pastures. It flowers very late indeed.

Some botanists have confused this worthless plant with the cultivated cow grass, Trifolium pratense perenne.

\section{Woodland Cow Clover (Trifoliun pratense, var. Sylvestre, Sime).}

Trifolium syluestre is not only indigenous, but exceedingly common in the eastern counties, notably in the valleys of the Yare and Waveney. Found as it is on most good pastures, its presence is accepted as a favourable indication of their quality, which seems to be supported by the fact that as soon as one begins to improve marshy or even wet ground it is noticeable.

When writing these notes we turned to a copy of a book on flowering plants, published by the Naturalists' Society (vol. 3), in which Mr. W. D. Geldart, a local botanist of considerable repute, had written an article upon Trifoliums. Our reference shows us that although he mentioned sixteen varieties as occurring in Norfolk, Trifolium sylvestre was not included amongst them; and as the Rev. K. Trimmer follows his example, we can only infer that this plant is known in Norfolk under some other name.

We were considerably astonished at this apparent omission, and, unless we have surmised aright, can hardly understand how it could have occurred.

Trifolium sylvestre seems to have nothing in common with Trifolium medium, except its perennial nature. It seems to be more of a dwarf Trifolium, and in comparison with others its roots are more fibrous, whilst the plant itself consists of a number of small stems with the flower nestling closely to the base of the leaves. It flowers very early, about a fortnight before common clover, three weeks before Trifolizm pratense perenne, and a month before Ti ifolium medium. 
Stock are intenscly fond of Trifolium sylvestre, which, in spite of its great difference in character, is sometimes carelessly mistaken for Trifoilum medium.

As long ago as $\mathbf{I} 888$ we were puzzling over these wild clovers, and one day we cut out a sod with a whole plant thereon in full bloom, which we sent to Mr. Martin Sutton, the author of the standard work, "Permanent and Temporary Pastures," and requested him to let us know all he could about it. He at once wrote back declaring it to be Trifulium sylvestre, and he asked us to collect some seed, as he was desirous of experimenting with it with a view to its more extended cultivation.

Recently we wrote again to him on the subject of Trifolium syluestre, and by his courtesy we are enabled to publish the reply we received.

Mr. Martin Sutton, writing from Kidmore Grange, Caversham, on December I gth, 1895, says :

"In reply to your very kind letter, I may say it is a great pleasure to be any service I can to you in this matter of differentiating Trifolium pratense, Trifolium sylvestre, and Trifolium medium. I have thought it best to send you dry specimens of the three plants.

"Trifolium sylvestre is really not a distinct species, but a variety of Trifolium pratense. It is earlier flowering, produces little or no seed, and is found growing in old meadows which have not been resown for many years. It blooms a fortnight earlier than Trifolium pratense, and quite a month earlier than Trifolium pratense perenne-the true single-cut cow grass in commerce.

"Trifolizm medium, on the other hand (zig-zag clover, the cow grass of some botanists), is never found in meadows or pastures, but generally in ditches, hedgerows, and waste places, on wet heavy soils. It climbs up briars and thorns, much as 
honeysuckle does. It has a brilliant red flower, a very dark green thick leaf, a deep tap-root, often half-an-inch thick, and no stock will eat the foliage, unless starved to it, it having an intensely bitter taste. I have collected seed from wild plants in South Wales, Yorkshire, and Ireland, and sown them side by side in our trial grounds. On the thin gravelly soil there, the plant becomes much less rank growing, and assumes a dwarf, dense habit, whilst retaining its distinctive botanical characteristics. Its bright crimson flower and laurel green leaf enable it to be distinguished from all other clovers a long distance off.

"I have not the slightest doubt that the true single-cut cow grass you and other practical farmers know so well, and appreciate so highly (but which some botanists refuse to acknowledge), is the result of a cross between Trifolium pratense and Trifolium medium, retaining, as it does, all the succulence and attractive flavour of Trifolinm pratense, and obtaining from its other parent the long tap-root, the woody stem, and the staying late-flowering qualities of Trifolizm medium.

"I need not ask you to be so kind enough to take every care of the specimens sent you, and to return them at your convenience.

"I ought just to add that the specimen of Trifolium medium sent, is one that was grown after some years' cultivation in our trial ground, and not a type of the plant in its rampant wild state."

With the letter he sent us for inspection some beautifully preserved specimens of Trifolium medium, Trifolium pratense, and Trifulium sylvestre. They are before us as we write, and much as we admire them, and greatly as they guide us, we cannot but again remark that a single specimen gives but an inadequate idea of the growth of any plant, so much do they vary by land, age, and other circumstances. 
The seed of sylvestre is very difficult to collect; we have found it of the usual clover shape, pale in colour, somewhat resembling lucerne or trefoil. We have been unable to make much progress in cultivating it, and cannot afford the time to make it a special study. We can only hope that others may be niore persevering and successful than ourselves, as the plant is indeed a valuable addition both to our pastures and to our meadows.

And now, after thus glancing at the four varieties, commor red clover (Trifolinm pratense, Limn.), single-cut cow grass (Trifolium pratense perenne, Sutt.), zig-zang clover (Trifoliume medium, Hudson), and woodland cow clover (Trifolium pratense, var. sylvestre, Syme), let us consider the question, "What is likely to have been the origin of the second variety, single-cut cow grass?"

Mr. Martin J. Sutton, in the first edition of his book, on "Permanent and 'Temporary Pastures," published in r 886, gives it as his opinion that for many weighty reasons it might be accepted that single-cut cow grass (Trifolium pratense perenne) is a hybrid between Trifolium medium and common red clover, and that opinion has not since been challenged. We cordially agree with it, and will give our reasons from our own practical observations.

Trifolium pratense perenn takes after Trifolium medium in the matter of late flowering, and in being of taller growth than red clover. It has also a deep searching tap-root, like medium, and a darker green leaf and deeper coloured flower than common red clover. 'Therefore, taking it that the coarse growing Trifolium medium of the hedgerow is the one parent, there is every reason to suppose the bees inoculated with its pollen a crop of red clover in an adjoining field, thus obtaining for the hybrid plant a portion of that succulence and quality which the common red clover had to impart. Then, again, perennial cow grass is not so freely eaten by animals as red 
clover, because it retains a tinge of the bitterness of medizım in it.

That Trifolizm pratense perenne is a cross between sylvestre and common red clover can hardly be urged; if such were the case it would flower earlier, its roots would be more fibrous and creeping, its growth more dwarfed than the red clover instead of taller, and stock would eat it more freely; now, none of these characteristics are common to perennial cow grass.

is $\quad * \quad * \quad *$

In concluding this part of our work we venture to hope that the kaleidoscope of agriculture will shortly turn, that a new vista will burst upon us to encourage capitalists to supply the ways and means whereby the cultivator of our soil may once more be put into a position to produce its fruits at a profit, instead of sending wealth abroad to increase the competition of food raising in this country, to the ruination alike of our landlords, of our tenant farmers, and of our agricultural labourers. Let us also hope that the present Government will take steps to carry out its election pledges, that it will do something towards decreasing our heavy rates, taxes, and burdens, and to enable the struggling agriculturist to successfully grapple with the times, and maintain that spirit of indomitable pluck, industry, frugality, diligence, and perseverance for which he has ever been famed. 

PART II. 



\section{CHAPTER I}

HEAVY SEEDS.

Alsike Clover (Trifolium hybridum).

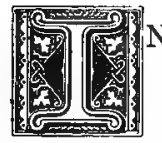

spite of the botanical name of this plant, we cannot but assert as our firm conviction that it is no hybrid at all, because of its distinctive habits which show no outward sign of its hybridisation.

Its name is derived from the town Alsike, in the south of Sweden; but why this particular township should have been selected for its nomenclature we know not, unless, perhaps it was that it was first cultivated there. It is, however, indigenous to latitudes of Europe which are situated much further south than the country we have named.

The blossom of Alsike is red and white pied, and the flower appears about ten days later than the flower of red clover.

$A$ few years ago we had an amusing instance which impressed upon our minds the different dates of the flowering of Alsike and of red clover.

A neighbouring farmer, who had planted one of his fields with a mixture of red clover, containing $4 \mathrm{lb}$. of Alsike, came to us in great distress. He stated that although his field was in full bloom, he could not discover a single blossom of Alsike, and, therefore, he thought it must have failed him altogether. We alleviated his troubled mind by suggesting that 
IO2 PRACTICAL NOTES ON GRASSES AND GRASS GROWING.

he should wait another fortnight, when we would visit the field with him, and we assured him he would find more Alsike blossoms than he would perhaps wish for. Wet weather supervening, he was compelled to postpone his hay cutting, and when, in accordance with our promise, we paid our visit to the field, he was astonished to find the whole area a mass of Alsike blossoms in place of the clover, and he then began to. have his doubts concerming the latter crop. The fact of the matter was that the Alsike, being the later flowering plant of the two, had been entirely hidden by the clover, but as the heads of the clover ripened and drooped, the Alsike showed up above them, with the result above narrated.

Alsike is rather peculiar in its nature. On certain lands it thrives so very much better than it does on others, and in some localities we have known part of a field to prove a great success, whilst the remainder has been a miserable failure, and for this result there really seems no accounting. Besides, the quality of Alsike is most varying, as also is its taste. With regard to the latter, we may draw attention to the fact that some farmers assert their stock like it immensely, whilst others emphatically declare that theirs will not touch it.

Except for seed, it is not a desirable crop to grow alone, or even in a preponderance, because stock are not over partial either to the herbage or to the hay, but it makes a grand mixture, especially on wet bottomed or cold lands where any doubts exist of clover standing.

It simulates white clover in many respects, but its upgrowing nature renders it superior to white clover for hay, and in any mixture for permanent pasture it is advisable to add a pound or so of Alsike per acre.

Alsike is perennial, but it will sometimes burn on scaldy lands, although on some light lands it is sufficiently vigorous to render it valuable, and it is a very hardy plant. At the same time it must be remembered that its habitat does not lie in light land, but in moist and heavy soil. 
The original Alsike has been so improved by cultivation that it has almost grown out of recognition, and the Alsike now used can hardly be termed expensive; still we doubt if it will ever become popular, although it is worthy of consideration for land on which clover will not stand.

When it is sown in conjunction with Timothy or Loliums it should be cut in full blossom, or it is apt to rot and die, especially if it becomes lodged. If cut when fairly young. it will continue to grow each year, although not so vigorously as in its maiden effort.

Its seeds are about the same size as white clover, green in colour, but in thoroughly well-ripened samples they attain a very much darker hue and are almost black. Samples of Alsike are infested with weeds, more so, perhaps, than any other clovers, therefore in all cases they should be thoroughly sifted and cleaned before sowing. Sheep's sorrel (Rumex acetosella) seems to be the commonest of these weeds, which is, perhaps, accounted for by reason of its also being a lover of moist and heavy land.

Like white clover a bushel of Alsike should weigh about $66 \mathrm{lb}$, each pound containing nearly three-quarters of a million of germinating seeds. In Canada, Alsike seems to succeed better than it does in Europe, and Canadian samples are not only cheap but excellent in quality.

\section{White Clover (Trifolium Repens perenne).}

White clover, the commonest and best known of all clovers, grows everywhere and anywhere. It was first cultivated in Holland, and thus has attached to itself the name of Dutch clover, although it is indigenous to this country. The samples which come from the Netherlands are certainly equal, if not superior, to any of our home growths.

The bête noir of white clover is red robin, a wild geranium, 
which is often overlooked, although its presence in the sample is easy to detect if care is taken.

White clover seed, when once ripened, will keep good for years if the air is kept from it. It will not germinate well if deeply buried, and many are the instances recorded where seeds, which have laid dormant in the land for a considerable period, have taken root and flourished in an extraordinary manner when the land has been again disturbed.

Although of a spreading, creeping nature, the white clover plant has a tap-root. It starts growing late in the spring, and makes the greatest headway during moist warm weather; often it spreads to such an extent as to become a nuisance. Being a very hardy plant, it will sometimes thrive where almost all other grasses fail, and for this reason, if for no other, it is a valuable plant, and can be included with advantage in any mixture and on any land, either for permanent pasture, or for one or more year's ley; but the land most suitable to it should contain marl, gravel, or gravelly clay.

Not arriving at maturity until late in the season, it is unsuited for hay; it is distinctly an autumn and summer grazing plant. Stock are fairly fond of it before the head (white in colour, coming at the end of a stalk devoid of leaves) has fully developed, when they seem to prefer other grasses; but it is highly nutritious, and is valuable for its creeping propensities, as it covers the ground and forms a good flag to plough in, for which purpose alone it well repays the outlay of $2 \mathrm{lb}$. to $4 \mathrm{lb}$. of seed per acre. $20 \mathrm{lb}$. per acre is the full complement. It weighs about $66 \mathrm{lb}$. per bushel, each pound containing upwards of 700,000 germinating seeds.

\section{Trifolium (Trifolium incarnatum and alba).}

There appears to be but one genuine species of this plant, although the four sports therefrom are used in alternate 
Busbandry, namely, Early Scarlet and Early White, Late Scarlet and Late White; but as far as we are able to judge there appears to be practically no difference between the white and scarlet, beyond the colour of their blossoms. The plant is largely used for mending inferior or imperfect leys, and in doing this it is desirable that what already exists in the ground should first be studied in order to procure a crop which will arrive at maturity at the time required. Trifolium is more a plant for feeding than for hay, but when used for hay it must be cut earlier than almost any other biennial, as, if not cut very young, or as soon as its seed heads give the first sign of colouring, its produce will be found of an inferior quality, although the quantity may be great. Trifolizm stover which has been allowed to grow old before it is used for feeding purposes, must only be used with great caution, because the stalks are so fibrous after the heads have fully developed and flowered, that stock feeding on them are wont to sicken and sometimes die from the balls which form in their intestines, and the constipation caused therefrom.

It may be more familiar to some if we refer to these Trifolium Balls as "Silver Cotton," or hair balls, the effect caused is very similar to that of overfeeding with undecorticated cotton cake.

The general advantage derived from Trifolium appears to be that it will bear a late sowing in the autumn, and the seed does not require to be buried, as the first showers will cause it to :germinate, even though the seed may lie quite bare above the surface of the soil.

Although sown late in the autumn, the plant on the advent of spring soon forges ahead of almost all other spring vegetation, and stock and young lambs (for which latter it is : specially adapted) are immensely fond of it. On odd pieces - of land which are not cultivated until the month of May, Trifolizm will be found a valuable friend. Although the plant 
makes its growth during the rainy season, it does not thrive upon wet-bottomed lands; but on almost any light land whereever one requires feed and has weak leys, Trifolium may be sown with advantage.

During the latter period of its ripening, it deteriorates with every shower. It harvests very rapidly, and is reputed not to grow properly except when used in the same summer in which it was harvested. Upon this point we would say that seed well ripened and harvested, and sown the summer after it was grown, will be superior to new seed sown and ripened in an ungenial summer. As with most other grasses, the best samples will be found the cheapest in the long run. In our opinion the best seed comes from Beauce, in France. In sowing, 16 to $20 \mathrm{lb}$. per acre will be found sufficient, and when used with Italian ryegrass, not so much is required, but the Iatter must be buried.

In using Trifolium for mending mixtures, a little red suckling or "alsike" may be added with advantage, and the proper time to sow will be found to be immediately after harvest, or before the end of September.

\section{Yellow Suckling (Trifolium minus).}

This is sometimes called "Red Suckling," because as it ripens the stalk assumes a ruddy hue, but there is said to be another variety, which has a green stalk.

Yellow suckling would appear as the most appropriate appellation, as both flower and seed are distinctly of a yellowish hue.

Without doubt it is one of the most useful plants we have, and it is a matter for conjecture that it is so little known outside the Eastern Counties. It thrives on almost any soil, and produces an abundance of good useful herbage very palatable to stock, but in dry seasons its growth becomes stunted. 
Although a biennial, it is so free in reproducing itself that it amounts to a perennial, and under favourable circumstances. will produce two good crops, if the first is cut when young.

For mending indifferent layers it is one of the best.plants. extant. This was recently exemplified to us in 1893 , when we renovated part of a field consisting of mixed soil on which the ley had been entirely burnt up, by sowing $2 \mathrm{lb}$. per acre of yellow suckling early in September. The wet summer of $\mathrm{x} 894$ favoured it, and we obtained two enormous crops from that part of the field we had treated as above mentioned, whilst the remainder proved a complete failure.

The seed requires well ripening and harvesting, when; like clover, it will retain its germinating powers for several years. In wet summers it is most difficult to get seed that has good germinating power, hence only the best samples should be bought. Sown sometimes in the spring, but more often in August, it is not harvested until the following July.

$W$ ith all trefoil mixtures we would recommend the addition of $\mathrm{I} \mathrm{lb}$. to $2 \mathrm{lb}$. per acre of suckling. When growing it is often mistaken for trefoil, although its habits are entirely different, and it spreads and tillers, under favourable circumstances, to such an extent, that only one-fourth the quantity of seed is required to produce similar results to trefoil.

We have seen suckling growing on the gravel ballast of railway embankments, and on pure black peat, but it seems to be a lover of moisture and of noist bottoms.

A bushel of the seed weighs about $65 \mathrm{lb}$, each pound containing on an average three quarters of a million of germinating seeds.

\section{Trefoil (Medicago LUpUlina).}

Next to clover, trefoil is the most known, the most used and the most popular of heavy seeds, but we would venture to 
IO8 PRACTICAL NOTES ON GRASSES AND GRASS GROWING.

at'once brand it as the most unsatisfactory and the most disappointing.

Red clover being so uncertain a crop, and never at all dependable on the same land, except after a period of eight years at least, the perplexed farmer is often inclined to select trefoil as the lesser of two evils; with more consideration we think he could do better. This he usually sows on the lines of the old adage laid down by his forefathers, "a peck of heavy with a peck of light," and to this mixture he adds 2 lb. to $4 \mathrm{lb}$. of white clover-a peck of perennial ryegrass generally being the light seed selected, or perhaps he choses Italian rye. grass. In so doing he entirely ignores the fact that a peck of perennial will go as far in seeding the land as a bushel of Italian ryegrass, or a peck of clover as far as two pecks of trefoil; and then he wonders at the failure of his layers.

Cow grass and Loliums, Alsike, or white clover, Loliums, and red suckling, would doubtless form a better mixture for him; but as he fears they may impair the efficiency of his clovers when their turn comes round, he falls back upon trefoil, or a trefoil mixture.

Trefoil is an uncertain cropper, and a captious plant, although it appears to grow on almost any soil. It likes good living, and gives but poor results upon inferior land. It will stand cold weather fairly, but not perfectly. The same remarks apply to dry weather, but it likes the rain, little and often, in preference to a surfeit. By reason of these peculiarities it is rare that we have a season particularly suitable to trefoil growing.

It flowers a fortnight earlier than clover; although it is an early spring grower, it is not a plant well adapted for hay. If cut before the seed pods-which are at the bottom of the stalk -are quite black, the hay is bitter, and will be rejected by stock ; but it produces early feed, and in some seasons plenty of it. Still neither stock nor sheep are over partial to its taste, and do 
not thrive well on a trefoil layer unless they have access to plenty of other feed; indeed, it is sometimes difficult to get them to touch trefoil at all.

Like suckling, trefoil is a biennial, but as it seeds itself freely, it becomes almost perennial. Thus $\mathrm{I} \mathrm{lb}$. to $2 \mathrm{lb}$. of the seed may be added to permanent mixtures, and it is so cheap that its cost need hardly be taken into consideration. On account of its uncertain nature we sow $2 \mathrm{lb}$. to $3 \mathrm{lb}$. of white clover, and $2 \mathrm{lb}$. to $3 \mathrm{lb}$. of red suckling with an alternate trefoil ley; the red suckling in case the spring should turn wet and cold, the white clover to form a bottom in case of heat and drought. To this we add $6 \mathrm{lb}$. of perennial ryegrass, or $20 \mathrm{lb}$. of Italian ryegrass, and as trefoil neither spreads nor tillers, it is desirable to fix the amount of it at $30 \mathrm{lb}$., which proportions the mixture.

The seed is slightly smaller than red clover, shaped like a pig's kidney, and can easily be distinguished from clover seed.

In colour it is a greenish yellow, but turns brown with age, ripeness, or weather.

The ripest and best samples are those which are neither too brown nor too green.

The plant is fibrous rooted, biennial, and in appearance resembles red suckling. It is indigenous to many places, and there exists a variety of the same species, an annual of inferior quality; but this smaller variety is easily detected, as its seeds exude a powerful aromatic smell quite different to the Medicago lupulina. This variety can hardly be called a weed, as it is comparatively harmless, and when present on corn stubbles, quite makes up for the objection it may prove to the growing corn crop by the after feed it produces.

In weight, a bushel of trefoil scales $66 \mathrm{lb}$., each pound containing about 300,000 germinating seeds. 
IO PRACTICAL NOTES ON GRISSES AND GRASS GROWING.

\section{Birdsfoot Trefoll (Lotus corniculatus).}

This may, perhaps, be called a fancy plant in agriculture by reason of its being so little used, and the seed is at all times difficult to procure.

Birdsfoot trefoil has certain advantages which render it valuable. It will endure any amount of drought, and will thrive almost as well on clover-sick land as on any other. It fills up the space underneath taller growing plants, thus increasing the crop, whilst it is less affected than most plants when grown on a bleak or exposed situation.

If birdsfoot trefoil were more known, we are of opinion it would be more used, and more appreciated.

Its seeds weigh from $65 \mathrm{lb}$. to $66 \mathrm{lb}$. per imperial bushel, and a pound should contain 400,000 germinating seeds.

\section{Kidney Vetch or Sand Clover (ANTHYllis VUlNeraRia).}

We are at a loss to know why this plant should be misnamed "sand clover," unless, perhaps, it is because at the first glance in an early stage of growth one momentarily mistakes it for alsike clover-a delusion which should at once become apparent on closer inspection, as it has little if anything in common with clover.

It is grown on inferior light and bleak sandy lands, or on lands with chalky sub-soil, where hardly anything except grasses, such as lupins, yarrow, or rib grass, will thrive. On this soil it will stand for some time, producing continuous and fairly good crops for several successive years if properly handled. It is certainly a perennial.

Kidney vetch is best sown alone, but it is sometimes used in conjunction with other mixtures, and on such lands as are above described, we think a few pounds of its seed can advantageously be added; indeed, it may be treated similiarly to 
clover or trefoil, the place of which it takes. It starts growing in April, and flowers in June (the petals are pinkish in colour), throwing out plenty of feed right away throughout the summer, and it is distinctly a sheep-feeding plant. Like lucerne, it weakens if allowed to become over developed, and it actually dies after being allowed to stand to cut for seed.

Should the crop be thin, it will be found a successful plan to allow its seeds to ripen, and, if the land is sufficiently clean, to turn a flock of sheep into it which will feed it, pull it down, and jam it well in, so that it will renew itself without further trouble or expense. Sheep do not always take to kidney vetch at first, but when they become accustomed to it they will thrive and do well on it. It is not at all times easy to establish, as it seems impossible to determine to a certainty, without previous trial, the land which is actually suitable for it; but when once it is established it will withstand any amount of drought.

In colour the seed somewhat resembles that of trefoil, but the former is dirtier and more greenish in appearance, whilst its shape is smaller and more like an egg.

If well ripened and harvested it will keep over-year, but an ordinary sample will not be found to germinate so well when kept over, and it very rapidly deteriorates in this respect. The quantity usually sown is $16 \mathrm{lb}$. to $20 \mathrm{lb}$. per acre. A bushel of seed should weigh about $65 \mathrm{lb}$., and each pound contains some 300,000 germinating seeds.

Mr. E. Mornement, of Roudham, one of the oldest and most experienced light land farmers in Norfolk, and who has for many years grown kidney vetch, writes to us as follows :-

"For kidney vetch one thing is absolutely necessary. During the first two or three years as it grows rapidly, it must be kept fed very close, or sheep will 'blow,' and the plant deteriorate if allowed to run up at all. I should certainly grow nothing with it, as it will not bear to be in any way choked. 
112 PRACTICAL NOTES ON GRASSES AND GRASS GROWING.

"Your views of its self renovation by allowing it to seed fully when necessary are right, as well as the description you give of soil suitable for it ; but it will not last more than about six years, and most light lands will become very foul of speargrass by that time. I should advise no seed more than one year old to be sown except it has been very well harvested, and certainly not more than two years, or yearlings."

\section{YarRow or Milfoil (ACHILlea millefolium).}

Yarrow is so nearly like a weed which grows on light, sandy brows and banks (on a parity to zig-zag clover), that it is difficult to distinguish; it also reproduces itself by root growth, as twitch or speargrass does. Still many people sow it on light sandy land in their permanent mixtures when they are able to procure the seed, which is not at all times an easy task.

Its foliage is very beautiful, being elegantly fimbriated, and in July it bears a pale elaborate flower spike. Under certain circumstances and conditions stock will feed it closely down, whereas at other times they will not touch it. It seems particularly adapted for hot, gravelly, dry soil. During a hot, dry summer it will thrive where other plants cannot exist, and once established it is everlasting.

Weighing $34 \mathrm{lb}$. per bushel, each pound has about 3,000,000 germinating seeds.

\section{LUCERne.}

Amongst the most early known and widely used grasses for forage crops lucerne, perhaps, would be the first mentioned. It is largely cultivated, not only in Europe, but also in North and in South America, where it is called Alfalfa ; also in Persia and in the far east. Mention will be found of it in "Virgil," which gives some idea of the number of years it has been introduced. 
It is, without doubt, one of the most valuable crops that England produces, and when once established on suitable land it yields from 20 to 30 tons fer acre of superior folder, a ton of which is quite equal to 3 tons of vetches-a good comparison to give.

We cannot understand why lucerne is not more generally known than it is, but apparently the English farmers have not studied it sufficiently, and before the grass has had time to become established they condemn it as a failure, complaining of the expense or other reasons, which a little patience and thoughtfulness on their part would soon overcome.

To our mind "Provence" would be more appropriate than its present name, because the department of Provence, in France, is, without doubt, its home ; and the best seed we have always comes thence.

The seed from America is nice looking, but the grains are small, and although on some land it thrives well, on others it will be found disappointing, particularly during the first year of its growth. Russia also sends us lucerne seed, which may be bought very cheaply, but we cannot recommend it.

It is asserted that lucerne is entirely independent of the surface soil, and derives its sustenance from the sub-soil and the air. If this be so, the grower should take into account his sub-soil rather than his surface soil, which may be the secret of many failures; and when the surface soil is removed, which in some cases could be done with benefit to other parts of the land, the finest crops of lucerne should be obtained; because there is no other plant we know of that deteriorates so much by overcrowding; therefore, by removing the surface soil, weeds and seeds lying dormant in. the land would be removed at the same time, and little else would grow upon the exposed sub-soil except Poa annua, which would be of little moment.

We have not tried this experiment ourselves, and until it has been practically demonstrated we cannot bring ourselves to 
believe that lucerne is altogether indifferent to the nature of the surface soil.

Iucerne prefers good $d r y$ land, and its roots penetrate the soil to an incredible distance, 40 feet not being uncommon. American authorities give 60 feet as the depth, possibly they are not incorrect. One instance we think wortlyy of recording.

In a letter to The Fieid, dated March $28 \mathrm{th}$, 1896, signed "Traveller," we read:- "We were laid up on a Columbian river under a bluff about roo feet high, when I happened to notice that the boat was made fast in front of a huge root. My curiosity was excited, and I put the query to the raw-boned skipper, who replied, 'That's the roots of the farmer's Alfalfa, the darned stuff is creeping down to get a drink at the river, as it don't rain of no account in this country.' "' The traveller here admits that the statement was so startling, he doubted it, but he goes on to say that he measured the root and found it, as far as he could recollect, to be nine inches in circumference. In conclusion he stated the skipper was a man generally regarded as truthful.

From the fact that lucerne gathers much mineral matter and nitrogen, which is a value to plant life, and, being leguminous, it also extracts much from the air, both of which it deposits near the surface of the soil, we draw our conclusion that it is a most valuable producer, and most beneficial to the soil for the vegetation which follows it. Our experiences show us that these foods are only auxiliary to the surface soil on which it largely feeds, and that lucerne is also amenable to the plant food which may be deposited upon the land during its dormant stage in the winter.

When selecting the land on which it is proposed to plant lucerne, it is, as we have before said, most important that the sub-soil should be studied, as it is of more importance than the situation (of the land), because if lucerne is sown where a suitable sub-soil exists the grass will be found to be comparatively independent of the cold, although a superfuity of 
moisture is most detrimental to it. The Eastern Counties being one of the driest parts of England, lucerne thrives well here, and secures all the moisture it requires by its deep searching roots and the absorption of dew by its leaves.

During autumn the land must be thoroughly cleaned, carefully ploughing in everything in the winter. At the first signs of spring, cultivate the land, thereby exterminating twitch, and getting up a growth of summer weeds, which are harrowed down again once or twice, when the land will be found in as firm a state as an onion bed. In May, sow 20 pounds per acre broad cast, or $\mathbf{I} 2$ pounds if drilled, but the former is preferable. Horse-hoe the land (cutting it all) as may be required, followed by seed harrows, when the lucerne seed should be evenly and lightly buried with all the deep-rooted weeds freshly cut, and the surface weeds practically exhausted. In September a good cut should be obtained-we have even known two cuts during the first summer.

Unless the grower is prepared to handle his land as we have suggested, he had better avoid the use of lucerne altogether.

When sown with a corn crop it is crowded from its very infancy, and being planted in light laying soil, one or the other is sure to be a failure.

When used with autumn sown wheat, lucerne has a little better chance. If sown early in April the grower can roll and harrow the land as much as he likes, which benefits the lucerne without injuring the wheat.

Lucerne may be cut all through the summer, the oftener the better, but it must never be allowed to stand after its blossoms begin to show colour. It should not be fed off during the first two years by either sheep or horses, as they bite the grass too closely. In the middle of October it should be allowed to grow about four inches in height, when it should be covered with a coat of straw made (farm) manure-sometime during iNovember or December. 
Lucerne sends down a large tap-root into the sub-sonl as quickly as it can, and it does not obtain maturity until the fourth year, when it is wont to shed the bark of its root, thus enriching the soil and creating a vacuum around the root which is highly beneficial. This process continues year by year, but does not commence until it is four years old.

Lucerne is chiefly used for soiling or ensilage, as it is somewhat difficult to make into hay, because the leaf, its most valuable portion, is wont to drop off as soon as the hay becomes dry, whilst it cannot be gathered or cocked when any wet weather or dew prevails, without risk of moulding.

It is almost impossible to make good hay from lucerne should a showery period intervene; at other times the produce must be gathered into small locks as soon as cut which the sun easily penetrates, and it must be carted early.

If grown for crops, three to four, according to the season, may be depended upon; but three crops will generally foot up to as much in weight as four. It is a plant which appears to grow at all times, no matter how hot and dry the weather may be, but during a wet season it lies comparatively dormant; thus a plentiful supply of lucerne can be relied upon when other crops fail, of which we have had ample proof during the past three years.

The duration of lucerne is another controversial point. We put it down at twelve years, but when properly. looked afte $r$ it seems to stand indefinitely, although twitch, if prevalent, will crowd it out in four years.

A spray of lucerne on a permanent pasture will last a long. time, and in our opinion is a welcome addition.

In appearance the seed resembles trefoll, and is of a yellowish green colour, but it is unlike trefoil in shape, being larger. The quantity of germinating seeds to the pound is about 225,000 , or one-third less than trefoil, whilst in weight it is less by $2 \mathrm{I} \mathrm{lb}$. per imperial bushel. 


\section{SAINFOIN-Cinquefoll (ONobrychis sativa).}

This grass is largely cultivated on both sides of the English Channel, and many people are under the impression that the name given to it by the French, "Cinq foin," indicates that, in their opinion, it is five times as good as the ordinary grass for hay. When we consider the quality and the quantity it produces, there may be some truth in the supposition; but without attempting to detract from its value, we think the greatest enthusiast in favour of it will have to admit this description is rather overdrawn. In our opinion the correct soubriquet is Cing foil-Anglice-five leaved.

Sainfoin was cultivated in England long before the present century, but whether the plant originated in England or in France will probably remain a moot point, although its settlement is of no importance.

For light land sainfoin is, without doubt, one of our most valuable plants ; its crop is abundant, and its produce is second to none in value, being superior even to lucerne. It is not always easy to establish a plant, as it will only grow on light lands which have a calcareous sub-soil, or where chalk is present. Sometimes it will thrive on sharp gravelly lands, but here it is liable to burn. It has also been known to take, when chalk is present, on heavy lands which are well drained.

There are two kinds of sainfoin, which are dissimilar from each other in their habits, namely, giant sainfoin, and common sainfoin.

Giant sainfoin is generally used in alternate husbandry, as it is not a perennial, and it yields a crop of seed after the hay crop has been taken off, which cannot be obtained from the common variety. It is usual to first feed giant sainfoin, or to mow it, then to feed it again. When the weather is warm and suitable it keeps constantly growing, but not being permanent, it is not so much in favour as common sainfoin, which stands 
I 8 PRACTICAL NOTES ON GRASSES AND GRASS GROWING.

for ycars when once it is established. Common sainfoin is usually fed until late in May, when it is shut up in order to secure the main crop of hay or the seed; after this it is of no further value.

In order to obtain a heavy crop it must be planted in good soil. The hay is excellent, but unless made in bunches a large quantity of the leaf (its most valuable part) will be lost in the making. It is leguminous, and the following crops are consequentially benefited by succeeding it. Unless the grower has good reasons for believing it will stand, he will find the seed expensive, and it requires four bushels per acre in the husk, the normal cost being about five shillings a bushel.

It is generally drilled either with, or immediately after, the crop of spring corn, and crossways to the corn. It should establish itself during the spring and summer, so its crop may be gathered during the following season. A prudent agriculturist would never destroy a sainfoin ley so long as a fair plant remained standing. Sometimes trefoil is mixed with sainfoin, but where the latter will stand, in our opinion, the only grass good enough to sow with it is lucerne.

In appearance it is hardly possible to distinguish the giant from the common sainfoin seed. The climate of France is more suitable to ripen it than that of England, and the samples which come from abroad are both good and cheap. It seems a controversial point whether the best samples are grown in England or abroad. In our opinion French giant sainfoin is better than English; but this is not so with regard to the common sainfoin, as it will not stand so long, nor is it so hardy as the home-grown seed. French samples are also most subject to burnet, and sometimes contain sainfoin dodder; whilst on the other hand the English samples occasionally have a spray of "blubber grass," an obnoxious weed somewhat similar to Yorkshire fog or Holcus. 


\section{Sheep's Parsley (Petroselinum sativum).}

Sheep's parsley is also a fancy grass, but is advantageously used in mixtures for sheep feed, these animals being intensely fond of it. Game preservers will also do well to sow it in their coverts, for it is a great attraction to hares, and the seed is neither difficult nor expensive to procure. One great drawback to it is that it lays a considerable time in the ground before making its appearance.

When sowing, 20 pounds per acre will be found all that is required, but one pound, or even less, is quite sufficient for a mixture in the ordinary way.

It is said to be an antidote to liver fluke.

\section{Tares or Vetches (Vicia sativa).}

There appears to be about one hundred different kinds of tares, but the reader need not be alarmed by anticipating it is our intention to refer to them all. In our opinion it will be quite sufficient if we sub-divided the species into two varieties, winter and spring tares. The former should be sown during the end of September or in the early part of October, the land having been first well manured. Where an exceptionally heavy crop is desired it will be as well to give them a second dressing of good farm manure when the field is covered with snow or bound by frost, which enables the dressing to be carted on to the land without injury to the crop. It is not uncommon to dress tares in the early spring with nitrates; but those who use this dressing appear to forget that tares are leguminous, and collect nitrogen by their leaves from the air more than they do from the soil, hence phosphates are better.

In selecting one's samples the buyer should always take a written warranty from the seller that the samples he buys are winter tares, as it is impossible to distinguish the variety by 
examining the seed in the sample, although many experts pretend they are able to do so. Home-grown samples are much more to be depended on than those which come from abroad.

Very good tares are yearly imported frcm Hamburg, which are called "Brunswick" tares; some of a more or less independable quality come from the Baltic ports, notably Königsberg. Besides these we occasionally use "Scotch gore tares" and "French runners."

The two latter we would not recommend to the buyer, but the former may be used as spring tares to his advantage; if these are used as winter tares, disappointment and bare land may be the result.

Referring to home-grown tares, we prefer yearlings to new tares, if sown early. More so is this the case when the seed has wintered in the straw. The reason appears to us to be that when yearling tares come up they grow slower and mature their shoots as they put them out, thus they become better able to resist frost than the rapidly shot out and longer shoots of new tares.

New tares are sown in October, when their chance of success is better, as so late in the season this rapid shooing is considerably modified. If cold and ungenial wenther sets in, old tares are apt to develop their shoots, which either rot or do not germinate, and sometimes never appear above the surface of the ground; therefore, the sowing of yearling tares after the first week in October is courting disappointment.

Winter tares are also sown in February and March, but after this month "Brunswick" tares often come cheaper, and answer just as well as winter tares; but it would be a great chance whether a sowing of inferior tares, no matter how cheap, would produce a successful crop.

It is a controversial point whether there is any difference between spring tares and winter tares. We are inclined to 
think there is no difference, excepting that winter tares have stood a winter which spring tares have not.

A local law case, which created considerable interest alike to farmers and merchants, may be appropriately quoted by us.

In the yenr I 895 a farmer bought a sample of winter tares from a Gorleston merchant, who had bought the tares from another farmer on the understanding that they were winter tares. The farmer who grew the sample had sown them in the autumn, gathered his seel in the spring, and according to the evidence he was perfectly right in describing them as winter tares; but the farmer who bought them in the autumn was dissatisfied with the crop he obtained, and alleged that spring tares had been sold to him in the place of winter tares which he had bought.

It appeared that severe frost harl at first stunted the growth of the crop, which, whilst the pleadings were progressing, considerably improved. A considerable amount of evidence was produced on either side, but none of the witnesses (many of whom were expert agriculturists and seedsmen) were able to satisfactorily explain the real difference between the so-called winter and spring tares, and the judge, in giving his verdict, carefully avoided the important question at issue, to the dissatisfaction of both parties.

During a mild winter it is possible spring tares will stand. and sometimes a field is sown with tares which stands in part and dies in part in accordance with the shelter afforded to the plants, or to other causes for which it is difficult to account. To say the least of tares, they are a crop which cannot be depended upon.

If tares are intended to be used for catch crops it is advisable to sow them with maize and other mixtures, as we have before recommended when dealing with that subject.

Apparently the best time for sowing such is in the latter part of July, as they then come in at a time when second crop 
clover and other soiling crops are over, and if the autumn be an open one, the tares will last on unt 1 December; in this manner the crop will be found to answer fairly well so long as they receive sufficient moisture during Midsummer. Tares will be found to yield an abundant crop, but not such a good one, nor so nutritious as lucerne or sainfoin. The crop is, nevertheless, extremely valuable when used with old hay and other fodder; also for ensilage. When making hay from tares they should be handled in the same manner as lucerne, although the hay at best is of indifferent quality.

It should also be borne in mind that it is not advisable to give tares too freely to one's stock.

Provided tares are fed or cut before they flower, or commence to flower, they tend to strengthen and improve the land, because they are leguminous. After flowering they have an exhaustive effect, the more so as they become older, when they will be found to impoverish the land almost as much as peas, or other grain crops. One difficulty, however, presents itself here; the crop improves in feeding value as it approaches maturity, and if found to be comparatively poor feed in its youngest stages, few will deny the excellent quality of the feed when in full pod.

\section{Blue Lupins (Lupinus augustifolius). YELLOW LuPINS (LUPINUS LUTEUS).}

Lupins are little known, probably on account of the fact that they only thrive on the most suitable soil, which appears to be deep sand.

Blue lupins, which are most in favour, are drilled in rows nine inches apart in May or June (similarly to peas or tares), one and a-half to two bushels per acre being used. If the land is suitable, no matter how poor the soil, the crop will be abundant. Sometimes the crop is ploughed into the land 
in a green state, which greatly benefits it, as the plant is leguminous; but it is generally found too valuable for this purpose.

At first shcep are not partial to lupins, but as soon as they acquire a taste for them caution must be used that they do not over-eat themselves, this feed being of an astringent nature, and inclined to cause sheep to become what Norfolk shepherds call "dizzy." Light land, cultivated with lupins, gives double benefit to the farmer, first by reason of the crop he obtains, secondly by the beneficial effect which it brings to his land, more especially after sheep have been folded on it, and when they have at the same time been fed with cake or corn.

Lupin seed is somewhat similar in appearance to small peas squeezed out of shape, and freckled all over with French grey spots. In taste they are so bitter that it is surprising any animals eat them at all. A superfluity of the seed is seldom seen on any market.

Mr. Edward Mornement, of Roudhan Hall, near Thetford, writes us the following, which we think worthy of production :--

"Your remarks on lupins need no observatihn from me, only as you say care must be used in feeding with them when they begin to ripen, because if sheep get a taste for them they will eat them too greedily, which occasions a sort of drunkenness, and flies to their head, and I have known them unable to stand for half a day afterwards. I mostly grow some, and shall put in some twenty acres next April, or early in May, as in a dry summer they are valuable in August or September. I once had a lot of seed that I could not consume, and fatted some shearlings on the meadows, and they grazed very fast on them the following summer." 
124 PRACTICAL NUTES ON GRASSES AND GRASS GROWING.

\section{Rib Grass (Plantago lanceolata).}

When dealing with pernicious weeds we had occasion to refer to rib grass, and we pointed out how obnoxious it was on good mix-soiled land on account of its tendency to outgrow and smother other grasses; but on poor light landed soils, where little else will thrive, rib grass may be cultivated, and is often considered a valuable crop for sheep feeding. On this land it will stand for years, and will yield any quantity of sheep feed, but the hay is of little (if any) value.

It is seldom sown alone, generally being mixed with ryegrass and trefoil. The seed is mostly procured by screening clover seed, and as it is sold as refuse, it is naturally cheap. When we remind the reader that this is the grass with which we in childhood's days were wont to play at the game of "fighting cocks," we think a further description of the plant unnecessary. Sown in April, ro to I4 $1 b$. per acre will be found ample.

\section{Burnet (Poterium sanguisorba).}

This plant is sometimes found growing with sainfoin, and people are wont to labour under a misapprehension as to its value. It is not until sainfoin commences to run to seed that the dissimilarity between the two becomes apparent, the latter (burnet) produces a quantity of useful food, and is not difficult to eradicate. It is not extensively cultivated, because sainfoin is distinctly the better plant of the two. 
PART III. 



\section{CHAPTER I.}

\section{LIGHT SEEDS.}

Perennial Ryegrass, Pacey Grass, or Bent (LOLiUM PERENNe).

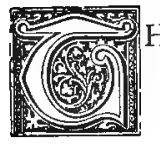

HIS is one of the most known, most used, and most popular grasses in cultivation, chiefly owing, we believe, to its low price and the small quantity required to cover the land.

It is used not only in permanent pasture (where it should ncver be ignored), but also in alternate husbandry. To ensure a plant it should be fairly well buried, and sown in the month of April or May. It is not a bad plan to put these seeds into the spring corn drill, as the corn can be horse-hoed before the heavy seeds of alternate husbandry are sown.

Six pound per acre is the amount generally used, but experience proves that $2 \mathrm{lb}$., mixed with red clover, suffices. When mixing for sheep feeding, the former amount mentioned, with trefoil, is correct.

In the north of Ireland and Scotland perennial ryegrass is largely cultivated, and some of the merchants, who are big buyers, have splendid machinery for cleaning.

In commerce it is valued by its weight per imperial bushel, the best weighing from 20 to $28 \mathrm{lb}$., the inferior 18 to $20 \mathrm{lb}$.; below this weight it is valueless. 
The buyer should use great precaution in examining his simple, because we regret to say some sellers are accustomed to manipulate the second-class seeds to give them an artificial weight, and we would recommend the purchaser always to give preference to the very best sample, which in every way will be found cheapest in the long run.

When this grass is properly used it will stand more jamming and rough treatment than almost any other species of grass.

It will be remembered that couch or speargrass cannot endure compressed land, therefore it should be obvious that if the grower notices couch in possession of the whole or part of his permanent pasture, perennial ryegrass should be sown, and the pasture folded with sheep, which should successfully clear the ground of the obnoxious weed.

The old adage, "if you don't at first succeed, try, try, try again," is applicable in this instance; choose, if possible, wet weather in the spring of the year for the second attempt, and, to make success doubly sure, it is advisable to spread 20 to 40 loads of mould-better still, a compost of mould and lime, or mould and gas-lime-upon the land before sowing.

When pastures are infested with moss, the remedy we have above described is also applicable. Perhaps it is needless for us to add that on heavy land the mould to select should be of the lightest kind available, and vice-versấ; on peaty soil or sour pastures use chalk or lime.

Perennial ryegrass is seldom grown by itself in England, and when sown with red clover it becomes ready to cut before the latter. Generally it is used with trefoil mixtures, although in alternate husbandry the ripening of its seeds may, in a measure, rob the following grain crop. When half grown, between the flowering and ripening of the seed, this grass has a greater nutritious value than at any other stage. In the spring it grows stronger than it does in the autumn, and under favourable circumstances, gives a fair a'ter math, and it loves 
nitrogen. In the Eastern Counties experts have found few old-established pastures free from this grass; in fact, it more often forms the chief growth.

In country lanes, road sides, cricket fields, or where there is much traffic, perennial ryegrass withstands all the compression which destroys other species. It is, therefore, of great value, being hardy, dependable, and indigenous to the soil in most parts of England, but at the same time it appreciates good living.

There are sixty or more varieties of ryegrass, but only Italian, perennial, or sports therefrom are worthy of our attention. For instance, we have Lolium vulgare, which is an annual; but why should we bother our heads concerning it when the vastly superior perennial ryegrass is available?

In conclusion, we would say that this grass was the first that was ever gathered and cultivated to the benefit of husbandry. The sample varies, perhaps, more than any other seeds of a similar kind; there are about 200,000 seeds to the pound.

\section{ITALian Ryegrass (Lolium italicum).}

When treating pastures with sewage first came in vogue, some twenty-five years ago, a great run was made upon this grass, and a fortune was said to be within the reach of any farmer who choose to cultivate it; but the results achieved by those who rushed into an undertaking, the nature of which they knew but little, could easily be anticipated. To put Italian ryegrass into a mixture for a permanent pasture is a mistake, except on very poor land, as it is a quick grower, a. gross feeder, a short stayer, and it dies down as soon as it has exhausted the nitrogen available to it.

Its effect should be obvious, it springs up quicker than anything else, sucks the goodness from the land, smothers 'other plants, then dies, leaving a bare space, or a few worthless stunted plants struggling for their existence. 
But there would never have been the run there was upon the grass had there not been some good qualities behind the scenes, which the careful experimenter soon ascertained and turned to his advantage. When properly used it will be found a thrifty as well as a hardy plant, and sown on the stubbles late in October it will often yield early and plentiful spring feed for young lambs, or other stock, or give an early swarth, second only to foxtail ; but it requires good land and constant feeding with nitrogenous dressings. The more you manure this grass the more will it grow.

There are extant many tales and instances concerning its marvellous powers of production in years gone by, they all point to one moral, which we would urge upon the intending grower: it is, "always experiment before using this grass in large quantities."

Italian ryegrass may be sown in early spring, or at any time when there is warmth, manure, and moisture; although a biennial it will last for several years if plentifully fed and cared for.

Beyond the reasons above-mentioned, we would not recommend it to be sown with either clover, trefoil, or hay mixtures, as it outstrips them in growth; but where it is intended to be fed and mowed hard it will be found a desirable adjunct.

When consuming Italian ryegrass we feed it up to June, cut what hay there may be in August, and feed it again afterwards. Sometimes we find it necessary to run the cutter over it again in September, as it is desirable to keep it down until late in the autumn. At one time this country was to a great extent dependent on France for its seed, but of late years the samples which have been exported from France arrive very foul, and now we obtain most of our best supplies from the north of Ireland, Scotland, and parts of East Anglia; notably the fen districts.

It takes a larger quantity of these seeds than of others to 
satisfactorily cover the land; three bushels per acre being usually sown when it is used by itself. It is said that one should sow about ten million seeds per acre for permanent pasture. Now as there are about 250,000 seeds to the pound estimated to germinate, a farmer who uses a peck per acre with his trefoil mixture, and does not find much grass resulting therefrom, should not be astonished at the result of his scant sowing.

In weight it runs from 18 to $20 \mathrm{lb}$. per bushel, and in one thing it differs from perennial ryegrass, in that it does not spread out and tiller so much.

Hard Fescue (Festuca duriuscula, Linn.).

We now have to deal with a very important family of grasses - the fescues, which are second only to the ryegrasses.

Hard fescue being cheaper and easier to obtain than others of its kind, we will deal with it first in our notes.

It is called hard fescue, because when the seed spikelets are ripe they should be quite hard. On suitable soils its use is most valuable, as it forms a dense bottom to the pasture, and has proved itself more capable of fighting its way among stronger grasses than any other of its species.

If we designate hard fescue "the poor man's grass" we shall, perhaps, imply more by that definition than we otherwise can in the rest of our notes which are made under this sub-heading.

This mainstay of the permanent pasture will always be found . extremely nutritious, and stock of all kind take to it freely. It will thrive on any kind of soil if not too moist, and on welldrained lands it will withstand a wet season as well as it will a dry one.

Not being of a creeping nature its seeds should be sown with a free hand, except on wet or water-slain soil, because although not absolutely dwarfish by nature, it is distinctly 
I32 PRACTICAL NOTES ON GRASSES AND GRASS GROWING.

short, and gives trouble to cradicate when breaking up a. pasture.

Hard fescue is distinctly perennial, and starts growing early in the spring. It produces a continuous and heavy amount of feed when properly handled-it is good grazing grass, and being short it does not give an abundance of hay, although what there is will be found of first-class quality. Flowering towards the end of June or early in July, it is robust in habit, and when the season is not wet enough to give it sufficient moisture to grow upwards it has a tendency to creep, and it does not appear to lie dormant under any circumstances. It is not a gross feeder, and responds less to manurial dressings than most grasses; in fact, manure seems to start other grass to the detriment of hard fescue.

In one thing it has an advantage over all others, in that the sample is mostly pure. It gives about 500,000 germinating. seeds per pound, $23 \mathrm{lb}$. going to the bushel.

\section{Meadow Fescue (Festuca pratensis, Hud.).}

If hard fescue is democratic in its habits amongst grasses, meadow fescue is the reverse, and in contra-distinction we would designate it "the gentleman's grass."

On most good lands in England it is common, it does not object to a reasonable amount of moisture, and when wellfed it yields an abundance of produce of the finest quality. No grass thrives better under irrigation, provided the land be not water-slain, to which it has a great aversion; but it is remarkably hardy, and one of the last to feel the ill-effects of persistent frosts.

In a first-class permanent pasture meadow fescue and foxtail should form the leading seeds, as the foxtail comes early, whilst meadow fescue takes up the running as the latter wanes.

It is a controversial point which of the two stock prefer 
to feed on most ; but foxtail has the advantage of being early, and in the spring of the year stock are less dainty than later on, for which reason we would give the preference to meadow fescue.

It is a dear seed to sow, and it takes three years, under favourable circumstances, to arrive at maturity. The poor show it makes on its first appearance often causes it to be neglected by the seed seller, but those of experience would not be biassed on account of this, and the grower should use it freely on good land. Flowering towards the end of June, the seeds ripens in August, consequentially it is a splendid grass for hay. It is thoroughly perennial, and need never be exhausted by being allowed to get too forward before it is cut, as is often so detrimental to the earlier flowering grasses. An important point to know is that nearly all grasses deteriorate in nutrative value immediately after flowering.

The appearance of this seed is so similar to perennial ryegrass that one cannot distinguish between them without the aid of a microscope. Meadow fescue appears to be slightly more pointed at the small end than perennial, and the small cut-off petal which springs from the base at the lower end of the seed inside seems to be slenderer and longer than in perennial of equal size, instead of being thicker as it leaves the base, as in perennial grass.

As this seed costs four times as much as perennial ryegrass, it is important to see that you get the genuine article. 'In weight about $28 \mathrm{lb}$. goes to the bushel, and it is estimated that there are 225,000 germinating seeds per pound.

\section{Spiked Fescue (Festuca pratensis, var. Loliacea, Hud. Hoo Bab.).}

This is a moist land-loving fescue, which is so similiar to meadow fescue that there does not appear to be any 


\section{I34 PRACTICAL NOTES ON GRASSES AND GRASS GROWING.}

difference between them, and we cannot understand why any grass grower should trouble himself to endeavour to procure this particular strain. We are of opinion that this is only a sport of the meadow fescue, and when sown side by side with. it we maintain that it is next to impossible to tell the one from the other, besides it has the disadvantage of being a reputed hybrid.

\section{Tall Fescue (Festuca eliator, Linn.).}

This coarse grass thrives well on wet soil, but whatever may be its virtue, we at once warn stock-keepers against it.

In its flowering stage it is liable to ergot, which is disastrous. to breeding animals, and when there are so many more superior and less dangerous grasses, it is better to avoid one of this description, except in places where it is so wet that it is difficuit to get other plants to grow.

On our Norfolk and Suffolk marshes it grows wild, and in the swamps and ditches attains gigantic proportions. It is there cut with the sedges and rushes, and used for litter.

When one has seen this grass growing as we have mentioned, and also growing on cultivated soil, one can hardly believe they spring from the same seeds; but there appear to be several strains of Festuca eliator, which may account for the difference.

Some time ago this grass was exported to New Zealand, where, like the meadow fescue, it grew to such enormous proportions that they called it reed fescue, and some of its seed has since been returned to the old country.

Another reason against its use is that it is difficult to get the seed pure, besides which it is very dear in price.

In appearance it somewhat resembles the seed of meadow fescue, but is, of course, much larger and coarser. Inclining somewhat to creeping habits, it can be propagated by dividing the roots. 
We do not believe that any practical farmer conversant with it would care to encourage it except on litter-growing grounds, where it will stand extreme moisture or drought, and continue to grow when other grasses fail.

Stock eat it freely in its young stage, and we have heard it recommended for very poor light land.

Its seeds weigh about $25 \mathrm{lb}$. per bushel, and one pound should produce 250,000 germinating seeds.

\section{Sheep's Fescue (Festuca ovina, Linn.).}

This kind of fescue, unlike others of its species, thrives best on dry soil; but it is not much used, because its seed is so dear and difficult to obtain.

It is a dwarf grass, and in these hard times Duriuscula is found better suitable to the grower's banking account, whilst it is perhaps the better grass of the two. Ovina is much used for grass plots and lawns, being one of the smallest grasses cultivated; what it lacks in quantity it makes up for in quality. The tiny tufts of dark green narrow leaves, rising from their slender seed stalks, are highly nutritious and valuable.

In Scotland and mountainous countries it is much esteemed, and it may be sown with impunity somewhat late in the autumn, except on dry ground, or pastures much exposed to the sun and wind.

It is a first-class quality grass, and is best used in conjunction with foxtail and meadow fescue, because it gives these grasses a better chance.

It does not flower till Midsummer, it grows under a foot in height, its roots penetrate to a great depth; but in spite of all this it takes several years to establish itself, and is so tiny in its early life that it is apt to be smothered.

Its seeds are very small, having a short awn, and small seeds sifted from other similiar grasses are sometimes palmed off on the buyer as Festuca ovina. 
I 36 PRACTICAL NOTES ON GRASSES AND GRASS GROWING.

$\Lambda$ bushel should weigh $28 \mathrm{lb}$, each pound of which is reputed to contain $\mathbf{I}, 500,000$ of germinating seeds.

\section{Red Fescue (Festuca rubra, Linn.).}

This may be classified as a fancy grass, but it is valuable in some respects, and therefore we have thought fit to mention it. It will stand even more drought than Ovina; in fact, when established it is very difficult to get rid of, and is even more hardy than Duriuscula.

It produces first-class herbage, and it is said that hares wilt travel for miles to secure a bite of it. It is distinguishable by the ruddy appearance of its leaves; unlike other grasses it grows more nutritious the older it becomes. A mixture of red fescue sown on very poor land where good grass is desired is to be recommended, and in a first-class pasture mixture, where the cost of seed is not a great consideration, it will be found not amiss.

Its seed is so similar to Festuca duriuscula that a separate description and estimate of its weight and germinating qualities is unnecessary.

Yarious-Leaved Fescue (Festuca heterophylla, Sutt.).

We should scarcely have mentioned another fescue except for the fact that this various-leaved fescue possesses the peculiarity of growing better under the shade of trees than it does in the open. Various-leaved fescue makes good sheep feed, and grows in tufts, which will not amalgamate with other grasses. The foliage has a somewhat darker appearance to most other fescues, but its seeds are so similar that it is difficult to give a separate description. 


\section{Fine-Leaved Fescue (Festuca tenuifolia, TibB.).}

This is another variety of sheep feed, but is mostly used for lawns and ornamental grass plots, therefore we do not propose to discuss it further.

Smooth-Stalked Meadow Grass (Poa pratensis, Linn.). Rough-Stalked Meadow Grass (Poa trivialis, Linn.).

The Poa family is of minor importance to the Festuca and other families of grasses; nevertheless it is of great value on certain lands adapted to permanent pasture, where its elegant seed heads cannot fail to attract attention.

Although Poa pratensis is separate and distinct in its habits and requirements from Poa trivialis, we have thought it better to couple these grasses for the purpose of our notes.

Poa trivialis has a broader leaf and a rougher stalk than Poa pratensis, the leaf is narrower and more pointed, whilst the stalk is smooth. The seed of Poa pratensis is straighter, and slightly hairy some distance from its base; whereas the seed of Poa trivialis carries its hairs from the base. On close inspection it will be found slightly scimitar-like in shape at the small end, whilst it is altogether slenderer than Poa pratensis seeds.

Poa pratensis is hardy, likes dry soil, and will resist drought; whereas Poa trivialis prefers moisture to drought, and it will grow and thrive under the drip and shade of trees, although it is more susceptible to cold.

Poa pratensis spreads from its roots, and rapidly forms a thick bottom swarth, which is sometimes thick enough to become a nuisance. Poa trivialis is of an upright growth, and fibrous rooted; it hardly spreads at all, whilst its herbage is more nutritious than Poa pratensis. From this it will be seen that it is better to sow Poa pratensis on light lands, and 
with a sparing hand, or it may crowd out better grasses; whilst Poa trivialis should be used on moist-bottomed lands. with a freer hand. It is curious that although Poa pratensis is a drought-resisting grass, it is not a deep-rooted one, and it depends on the surface for its sustenance; hence it is more adapted to a chalk or calcareous sub-soil than to sand. Mineral phosphates have a beneficial result when applied to this grass, whereas nitrate seems rather to discourage its. growth than otherwise; therefore, when it is observed becoming too abundant, a dressing with nitrate will check its growth, and at the same time encourage other grasses.

Poa pratensis has another peculiarity, namely, it is single cut, and it only throws up its seed heads once a year. It is, in fact, a turf-forming grass; it comes early, grows late, and resists cold. Consequently it is a good grass to grow, especially with foxtail ; but when sowing the two in combination, care must be taken to apportion each so that Poa pratensis does not check the foxtail by forming too dense a turf.

It has some similarity to Festuca duriuscula, but it requires. a better soil than the hard fescue, and its seed is more expensive. In considering this we must remember that hard fescue has only 500,000 germinating seeds to the pound, against $\mathrm{I}, 500,000$ which this seed is estimated to produce, and that Poa trivialis has over $2,000,000$.

\section{Annual Meadow Grass (Poa annua, Linn.).}

Por annua is the most frequently met with and indigenous grass in East Anglia. Wherever there is a small bare patch of soil in the fields, in the gardens, the walks, the drives, the roads, even between the chinks of the pavement, on the garden walls, the church steeple, or on the grave stones, this grass seems to flourish. As moss creates soil, so also is Poc annua a harbinger of vegetation on bare sterile land. A good 
sample of this may be seen in railway cuttings; it is the first grass to appear, collecting by its fronds from the air, and by itsfibrous roots from the ground, material which forms humus, thus nanufacturing for itself a surface soil.

$P o a$ annua seems more busy in reproducing itself than in throwing out herbage; it is a very small plant, but it sheds its. seeds rapidly, and afterwards dies down, thus are its seeds. scattered by the breezes, so that it is wonderfully prolific; but it is soon crowded out by other plants which grow more vigorously in the summer, and die down in the autumn, when Poa annua once more asserts itself. Lord Clifton, a wellknown and reliable authority on grass growing, mentions in some most interesting comments upon this grass:- "If Stillingfleet really found a park in Suffolk composed of Por annua, there must have been a constant succession of growth."

Upon bare land Poa annua will appear before any other grass, and soon covers the ground; but when stronger vegetation springs up it is smothered. It nevertheless lies dormant in the land, and fills up any vacancy that may occur. It is impervious to cold, and will continue growing so long as it obtains enough moisture; drought it cannot stand. In summer it arrives at maturity, and lives a shorter life than it does in the winter. We have seen it flowering and shedding. its seeds in December, and, in spite of the frost, it has been in full bloom again in February. It is beneficial to agriculture in a small measure, and there is no occasion to sow the seed, because it will come of its own accord.

Were it not for the above drawbacks it would be worth cultivating, as it is very nutritious, and animals seem fond of it; but the crop is so small that its value is doubtful.

\section{Wood Meadow Grass (Poa nemoralis, Linn.).}

This grass, in contradistinction to the last mentioned, will only thrive on dry soil. It comes early, will stand cold and 
IO PRACTICAL NOTES ON GRASSES AND GRASS GROWING.

drought, and likes the shade of trees. Stock are moderately fond of it, and it is an incessant grower, so much so, that it is sometimes called Semper virens. Botanists tell us that Poa nemoralis is a distinct species from Semper virens, but to the agriculturist no difference is apparent. It is of a dwarfish nature, and when true seeds can be procured it is excellent in lawn mixtures.

With all these fancy grasses, one runs a great risk when sowing, however careful the merchants may be in selecting their samples, because most of these grasses are gathered by hand, and bad and inferior grass seeds are inadvertently collected at the same time, which are next to impossible to eject ; for example, there is so little difference between the seed of Poa nemoralis and that of Aira caspitoso (hassock grass), that it is difficult to distinguish the one from the other in the sample with the aid of a magnifying glass; even then some difficulty is experienced. For our reader's information, we would point out that the seed of hassock grass is more shiny in appearance, is thicker in form at the lower end, where it is also fringed with tiny white hairs, whilst the awn protrudes upwards to the end of the seed.

Sweet Reed Grass (Poa aquatica, Linn. Glyceria, Smith, Bab.).

The name of this grass implies its nature. It flowers in July and August, thrives in very wet situations, and when used on water-slain lands often makes good hay. Stock will eat it; but there is always some difficulty in procuring dependable seeds.

\section{Crested Dogstail (Cynosukus cristatus, linn.).}

Crested dogstail is a short-growing, dwarfy grass, which assimilates itself to almost any soil ; it materially assists to form 
a dense sward, and is valuable for lawns. Sheep are very partial to it, and crop it down so closely that they do not allow it to make much headway. When freshly sown they will pluck it out by the roots, which they are not able to do after it has stood a little time, because its roots run deeply down into the sub-soil. This causes it to be a useful grass for land having dry, sandy, or chalky sub-soils.

Lord Clifton, who is a practical botanist of repute, writes us, "that crested dogstail takes almost complete possession of some of the Kentish leys on certain downy soils, which proves. more its value on sheep walks."

It also thrives on heavy land, and although it makes but little difference to the bulk of the hay crop, it gives a splendid after-math ; besides, it is a late grass, increasing in vigour as theseason advances, and it takes the place of many spring grasses which die down at that time.

It is perennial, and by its assistance to a judicious mixture a pasture may be kept going throughout the summer.

The casual observer sometimes mistakes crested dogstail for ryegrasses of the Lolium family, but the habits of each are so separate and distinct, that we rather wonder thereat.

Like many other grasses, it is greatly weakened if allowed to ripen its seeds, and when a pasture is neglected dogstail suffers severely. The old stalks stand the winter, and when left they give the pasture a very rusty appearance in the spring. With the seedsman crested dogstail will never be a fayourite grass; it cannot be called cheap, and during the first year of its growth it gives very little show for the money expended on it ; still, the careful agriculturist seldom ignores it when laying down his permanent pasture.

The seed of Melica carulea, Linn., which is a rough inferior grass, and only useful to make litter and cover for game, very much resembles crested dogstail ; but the seeds of the former are lighter in weight and darker in colour, and may easily be 
detected in a sample by spreading it (the sample) on a sheet of paper and shaking it, when the light seeds will all come to the surface.

Good crested dogstail seed should weigh over $30 \mathrm{lb}$. a bushel, and contain about three-quarters of a million germinating seeds to the pound.

Since writing the above we have again heard from Lord Clifton, who kindly informs us "that in his county of Kent the rule is to mow hay as soon as the green spikes of dogstail appear among the other grasses; also, that it always surprises his lordship to see how conspicuously these seedheads show up in a stalk."

Meadow Foxtail (Alopecurus pratensis, Linn.).

This grass may well be described as one of the grandest grasses grown. It thrives on all kinds of soil (even under trees), and on heavy land; it loves irrigation, but on undrained or water-logged soils it will not stand; for choice, it prefers a good retentive soil, and it makes but little headway upon poor or light land.

It produces an abundance of herbage, of which all classes of stock are immensely fond; it reproduces itself, and it comes a second, and even a third time, although the latter growths are not so vigorous as the former, and it is distinctly a spring grass.

The greatest drawback that meadow foxtail has is that it takes three to four years in coming to full maturity, and it is therefore useless to sow it on temporary layers. Being the earliest and quickest of spring grasses, it stands frost admirably, also cold winds. Flowering in April or May, it is quite fit for hay by the middle of the latter month, and should prove valuable to the flockmaster if sown with a selection of early varieties. Trifolium is almost the only plant 
that comes early enough to cut with it, but then this grass would have to be sown afresh each autumn, which, we fear, might prove impracticable.

In some parts of the country meadow foxtail is known as "guinea grass," because women and children in days gone by were wont to gather the heads and sell them at a guinea per bushel.

The weed most objectionable to it is Holcus, or Yorkshire fog, which we have before alluded to in our remarks on "Pernicious Weeds." The seeds of Holcus closely resemble the seeds of meadow foxtail, but they differ in that the long awn on the former is conspicuous by its absence from the latter.

In spite of the invariable dearness of the seed, meadow foxtail should always be included in a mixture for permanent pastures. A bushel of the seed weighs some I4 lb., and should contain in each about 400,000 germinating seeds.

\section{Sweet Vernal (Anthoxanthum odoratum, Linn.).}

Sweet vernal is an all-round grass. It thrives on any soil, coming early, and on light scaldy lands it flowers in May. On retentive soil it continues to grow late, but becomes coarse and reed-like where moist and spongy soil favour it. It throws a greenish flowering spike, with a ruddy bloom, which is easy to distinguish on a permanent pasture, where it is very hardy and thoroughly perennial, resisting the changes from heat to cold, and from wet to dry, better, perhaps, than almost any other similar species.

The great advantage of sweet vernal lies in its constant supply of green leaves, but this foliage is too broad and coarse for lawns. Stock are not particularly fond of it except in a young state, and on some lands it is apt to grow too prominently, to the detriment of better grasses.

Sweet vernal imparts a delightful aromatic smell to hay, and 
we consider that a spray of it should never be omitted from permanent or temporary pastures. Some agriculturists object to it on the ground that if they do not feed their pastures early. the seed spikes get so forward that stock neglect them in preference to other grasses; also, that when the grass seeds down it causes a surfeit to be reproduced. Still, to those who require early feed and an all-the-year-round green-looking pasture, it is invaluable.

The seed of sweet vernal is often difficult to procure, and is. generally somewhat dear, besides, it sometimes contains an admixture of Anthoxanthum puelii, which is an annual not nearly so good as sweet vernal; but its seeds may be detected by careful inspection, as the Anthoxanthum odoratum are longer in shape and darker in colour than Anthoxanthum puelii.

Unlike most other grasses, the herbage of sweet vernal is said to be more nutritious as the season advances, and to become more so in the autumn than in the early spring.

A bushel weighs about I 4 lb., and each pound contains on an average 450,000 germinating seeds.

\section{Tall Oat Grass (Avena eliator, Linn.).}

Tall oat grass does not seem to be so well known as yellow oat grass, although in our humble opinion it is the better plant of the two. It makes itself at home on moist soils, growing to three feet in height, even taller under favourable circumstances.

As its taste is somewhat bitter cattle are wont to pass it by. It starts growing early, and produces an abundance of herbage, whilst the second crop (if such be desired) makes excellent hay. It is not strictly perennial, its life varying according to circumstances and situation, but it often survives five or six years, and therefore should have a place in three and four 
years' ley, and an infusion of it will not be found amiss in permanent pasture mixtures.

Tall oat grass is a plant of such rapid growth, that it is naturally exhaustive to the soil, and, although sown in the spring, early autumn is its natural time for seeding, hence it constitutes an excellent renovator, and if it takes in the autumn, it will produce good crops during its first summer.

With tall oat grass a difficulty will always be found apparent, it likes to be buried deeper than most grasses, and it will be noticed that the grass springing from holes, cracks, or deep crevices, where it has found a lodgment previous to the action of the roll, will spring up strongest and best.

It is a very hardy plant, and well worthy of attention, although its seed cannot be called cheap.

Curiously enough it seems to thrive on the most exposed situations near the sea, and on wild places where only the coarsest herbage, rushes, or heather find a home. It is, however, amenable to cultivation, and will respond to sewage treatment, although such must be used with caution.

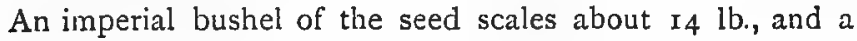
pound produces some 450,000 germinating seeds.

\section{Yellow Oat Grass (Avena flavescens, Linn.).}

This species thrives best on light soils having a chalk sub-soil, and sheep and cattle are exceedingly fond of it.

It is not an early grass, and is more adapted for grazing than it is for hay, as it produces a quantity of pale green herbage late in summer as well as in the autumn; it is a most useful grass to sow on inferior soils, as it does not require a rich feeding ground, and it will go on growing and throwing up conspicuous golden flowers when other grasses are comparatively stunted.

Its seed is of a light frothy nature, and somewhat deficient 
146 PRACTICAL NOTES ON GRASSES AND GRASS GROWING.

in germinating power. Without a very careful examination it is a difficult matter to distinguish the seed of yellow oat grass from that of wavy mountain hair grass (Aira flexuosa), which latter is a grass of an inferior description. The seed of the former is slender in appearance and of a lightish brown colour, whilst the seed of the latter is darker and stouter; they both have a bent awn protruding about two-thirds of the way up the seed germ, and bending outwards in the yellow oat grass, but which starts from the base in the wavy mountain hair grass, and at the back displays some long white hairs.

We think it desirable that yellow oat grass should not be ignored either in temporary or permanent pastures. It is amongst the lightest of grasses, an imperial bushel only weighing $\mathrm{r} 2 \mathrm{lb}$, and giving about a million and a half of seeds to the pound; but not half of this quantity will germinate.

The wavy mountain hair grass is a heavier seed, and, like all inferior imitations, it germinates very much better than yellow oat grass.

Timothy or Meadow Catstall (Phleum pratense, Linn.).

Timothy is a vigorous growing grass, but differs from cocksfoot in that it is later; it does not form such big stools, nor grow so vigorously after the first hay crop has been taken from it ; but it is more difficult to eradicate, and it is clearly a more cultivated species than cocksfoot. Again, it grows more erect and taller than cocksfoot, and the hay from it is more nutritious after it has been allowed to get fairly old, especially when the seeds are partially formed in the head.

The hay buyer may object to the coarse appearance of its sample, still, its value as food has been proved to be particularly increased if chaffed before it is given to the stock, thus preventing any undue waste.

It is a perennial, but it is not indigenous to this country, 
where it was introduced over a century ago from America, by a Mr. Timothy Hansen; hence its name. In the latter-named country it is the staple alternate grass, and is known as "blue grass."

Timothy is sometimes grown alone with great success, when it can be treated as its nature requires, but it is quite useless to sow it on dry, sandy, or gravelly soil, because, although it resists cold well, it is of a thirsty nature.

It is a popular grass, largely used, and will continue so to be as long as its seed remains reasonable in price.

One pound of its seed is estimated to produce over a million and a quarter of germinating seeds, and it is the heaviest of all grass seeds-one imperial bushel scaling about $50 \mathrm{lb}$.

\section{Cocksfoot (Dactylis glomerata, Linn.).}

This grass, although popular with many, we class with the semi-weeds. Nevertheless, it is most useful on poor and inferior land, where it produces freely.

Planted in and near to game preserves it is admirable, it produces fodder for the hares and rabbits, whilst the big coarse bunches of grass form splendid cover for them to lie in.

On good land it grows up like the proverbial thistle, smothering everything else; whilst other grasses are seldom, if ever, found entwining themselves in a stool of cocksfoot.

Where it has been introduced, and the soil suits it, it comes to stay.

It is found on brows, in pits, and in hedgerows; in fact, it will take possession of every spare spot on the farm, putting forth its wiry stems and ugly heads (which sometimes have the disadvantage of being ergotty) until the farmer is driven to desperation by the failure of his attempts to eradicate it.

- It is like Italian ryegrass in that, on good soil, it will produce an immense crop, whilst it is unlike it in that it is a stayer. 
148-PRACTICAL NOTES ON GRASSES AND GRASG GROWING.

Being earlier than Tinothy, it is better adapted to sow with trefoil or red clover mixtures, and if cut continually and well fed down after the first hay cutting, it will continue to produce an abundance of feed in almost any weather; but the cutter should at once be run over it if many wiry seed-heads begin to spring up, as stock may feed it down in its young state, but they will not look at it when it is old; nor do they seem to relish it before the winter frosts have sweetened it.

Hungry ewes, for instance, will eat it if they are kept short enough to make them keep it down throughout, and in the early spring, when keep is short, it is useful for cattle, which will then thrive fairly well on it.

Hence one may draw the conclusion that for lands which are likely to be perpetually worried, by reason of a shortage of pasture, it is a valuable grass, but upon the ordinary permanent pasture it is nothing more nor less than a curse.

Cocksfoot amongst seedsmen will ever be a favourite; it is one of the most certain grasses to take in almost any soil under all circumstances, and it constantly keeps growing, punish it how one may.

Hay made from it (when old) is of little, if any, value.

From time to time large quantities of seed are imported from New Zealand, also from North America, but we believe it is indigenous to this country, although it varies considerably in localities. When once known it is not easily mistaken.

A pound of good cocksfoot seed is estimated to contain over 400,000 germinating seeds, and an imperial bushel would weigh about $2 \mathrm{I} \mathrm{lb}$.

Fiorin, or Creeping Bent Grass (Agrostis alba, or Agrostis stolonifera, LinN.).

The boundary between wild and cultivated plants, like everything else in nature, is sometimes so narrow that it is 
almost imperceptib!e. In this example the boundary between objectionable grasses and fiorin, cocksfoot, Timothy, etc., is of so narrow a description that many look on the above-named as weeds; but they have their advantages and values, or their culture would not be entertained. One of the chief advantages of fiorin is that it will thrive in a boggy soil, amid stagnant and water-slain places, where anything useful beyond Triticum caninum or rushes (which are chiefly useful for litter) would perish, and it produces an abundance of green herbage in early spring and late in the winter. During a mild winter it continues growing throughout, but stock will not eat it when they can get anything else.

On good moist land fiorin thrives well, and during a wet summer it takes entire possession of the pasture it occupies; altisough its roots run deep into the sub-soil, it seems deficient in capillary power, as it suffers from drought. Another disadvantage it has is that it is subject sometimes to be badly érgotted, a very serious matter for the flock or herd.

Its surface roots are of a creeping nature, therefore it will, under favourable circumatances, spread in a most alarming manner, and, being a gross feeder, it exhausts the soil to the detriment of other and better plants, hence it should never be used except on boggy peaty sloughs. This warning is perhaps urnecessary, as to procure the seed is next to an impossibility, and the seed which is sold as fiorin seed is, we have' good reason to believe, almost invariably something else.

The only way, apparently, to obtain fiorin is to take stools of the grass itself, dividing them and planting them out in September--during moist weather for preference.

Several other varieties produce seed so nearly in appearancé to Agrostis alba that few botanists can detect the difference, but the plants whèn grown will be found to väry considerably. 


\section{Schradus Bome Grass (Bromus schrrederi). Awnless Crome Grass (Bromus inermis).}

There are sixty to seventy varieties of the Bromus family, but we have only referred to three of them as, speaking generally, they are coarse and undesirable grasses to grow. Stock are fairly fond of some of them, and they are belicved to be of considerable feeding value. They are biennial, and grow with extraordinary rapidity; they soon exhaust the soil, and, being surface-feeding plants, starve out and smother most weeds, especially during a moist season.

The first cut sometimes exceeds that of Italian ryegrass in quantity.

We remember years ago it was said that Italian ryegrass would make the farmers' fortunes. The same was said of Timotlyy, only to be repeated of cocksfoot; but practical experience soon toid a very different story.

These grasses are exceedingly useful, in the same manner that other grasses are, but unless the grower uses judgment, he may not find them to his advantage.

Neither Bromus schraderi nor Bromus inermis must be confused either with Bromus moliis or with Bromus secalinus, which are troublesome weeds; the latter is sometimes found in other grasses, notably meadow fescue, the seed of which it much resembles, although it is somewhat larger.

We doubt whether cither of these two grasses is more prolific than Italian ryegrass under irrigation, yet at the same time we cannot understand why they should not have been receiving attention either from seedsmen or from agriculturists, and we would inform our readers they may amply repay the outlay if some consideration be given to them.

\section{Hassock Grass (Aira ceespitosa, Linn.).}

This curious grass is common in the bogs and swamps of Broadland in Norfolk and Suffolk: Iocally it is known as 
hassock grass, but what relation it is (if any), to tufted hair grass, we know not. Somehow or other it manages to get a footing on very soft ground, even on what are known as hovers (literally islands of floating mud held up by vegetable roots and sparse vegetation), and, having once gained root, it develops into tufts, and constantly keep throwing out long wiry fronds, which are very hard, and will cut the hands like a knife. As these fronds emanate from the top of the tuft, the increase forms a stool, extending in height and size in accordance with the age of its growth.

These hassocks are so strong that one can often jump from one to the other, and thus use them as stepping-stones over what might otherwise prove to be an impassable swamp; in fact, they are sometimes used as a foundation for roadways over swamps in place of faggots.

Like the white cedar of South Carolina, hassock grass on swamps seems to be the harbinger of the formation of sounder ground. It does not always seed, but in favourable positions it throws up two tall seed stems, some six feet in length, bearing the most elegant spikelets and seed glumes, which have a striking effect when used for ornamentation. Hassock grass is also useful as a cover for game.

\section{Dog's Tooth Couch Grass (Triticum caninum, Hud.).}

Although many consider this a weed of the worst character, we think it advisable to mention it, as it is not only edible, but will often find root where everything else has been destroyed by flood. It is also known under the name of fibrous wood couch grass (Agriopyrum caninum, Linn.). Like dodder, it is difficult to kill so long as it is fed by moisture, but, unlike other couches, it does not spread by its roots; it is not a creeping grass, and is without stolons. It is found in wet places, and if you examine a swarth of hay cut on boggy land and laid 


\section{2 PRACTICAL NOTES ON GRASSES AND GRASS GROWING.}

for a few days in a wet state, you are sure to see this grass. It will attract your attention by the white shoots, like dog's teeth, which spring out from every joint. If you carry some of it in a wet state and drop it on a moist place, it will take root where it falls. There are few bogs where it does not prevall; it is neither coarse nor large, but runs very rapidly, forming large masses of vegetation.

Should the land on which it grows become flooded and remain under water so long that the other grasses are destroyed, dog's tooth couch will survive, provided it has been able to extend a little of its foliage to the surface of the water, when the white teeth, before mentioned, will be seen protuding from every joint, ready to take hold of the soil on again being brought in contact with it. If exposed to drought it dies, as it cannot exist without water. By cultivation we believe it would be possible to grow hay with this grass on land where nothing except rush or water grass could exist.

\section{Marizam Mat Grass (Ammophila arundianacea, Hoo.),} Sand or Sea lyme Grass (Elymus arenarius, Linn.), and Esparto Grass.

The former of these grasses, which are all of one family, grow on the sand-banks and dunes surrounding the whole of our Eastern coast, where it holds the sand-hills together, which is of great value; whilst the latter is found serving the same mission on the northern coast of Africa, where it grows to far greater lengths than our home grass, and is largely used in the manufacture of paper. The general practical utility of marram grass is the manner in which it forms a natural barrier on the low-line sandy shores, where it collects the driftings and round its leaves, and by shooting long roots from its upper joints into the newly-formed sand-drifts around it, holds it secure, and preverts it from being blown away again. So great was its 
value at one time considered, that in the reign of good Queen Bess an $\Lambda$ ct of Parliament was passed for its protection.

In no place, perhaps, could a better example of its utility be found than upon Lord Leicester's property at Wells-next-theSea, in Norfolk. Walking along the beach one cannot help observing the high sand-hills formed by the marram grass, which constitute a natural boundary to the reclaimed marshessome of the finest pastures in Norfolk. Passing over the hills, and descending on the land side, we find sea lyme grass putting in an appearance. The nearer we go to the fertile land, and the further we go from the sea, so does the marram decrease, and the sea lyme grass increase proportionately, until the fertile land is quite approached, when the sea lyme grass gives way in favour of pasture grasses.

At the first glance sea lyme grass might well be mistaken for marram, but there is some considerable difference between the two; the stalks of the former are not so strong as the latter, and it is much easier smothered. The seed spikes of the marram grass are large and of a silky nature, whereas the sea lyme grass spikes are longer still and narrower, and in appearance more resemble that of the Loliums. Both these grasses have the power of retaining their seed in the hend throughout the winter, and it is only in spring, after the winter storms and accumulations of sand have been formed, that sunshine and shower causes them to shed their seeds so near to the surface that they instantly take root, an arrangement of nature which inaterially assists in preventing these grasses being smothered. We do not think the seed of this grass finds a place in commerce, but anyone desiring samples should not find great difficulty in obtaining them if they apply to people living where it abounds.

\section{NetTles.}

At first one might think that these weeds would be more of a nuisance than otherwise to the farmer, but we have seen so 
many instances in which they have proved valuable, that we think it advisable to give them a place in our notes. In the country some of the poor people cook them as vegetables, whilst it is a well-known fact that gipsies show a marked liking for them, and, if the truth were known, a large quantity find their way into the spinage which is served up in London restaurants. With regard to agriculture, they form first-class food for pigs; in fact, we know of many cases where farmers encourage them for this particular purpose.

So far as we are concerned we give our pigs nettles daily from May until after harvest. The younger the nettles are the more are they appreciated, and as the cutting of nettles modifies their growth, the crop is not a long lasting one.

Like twitch, nettles grow from underground roots, and they spread by their roots as well as by their seed. A big bed of nettles can, if so desired, be forked up and, with after attention, easily destroyed; repeated cutling will also destroy them.

One of our most valuable correspondents writes us, "that he considers nettles sometimes make good nurses to young grasses in a droughty season; also, that on waste ground, when left to grow freely, they almost exterminate docks and prepare the soil for natural grass, as they (the nettles) exhaust themselves by their own abundance." 


\section{Selections from Jarrolds' Jew Looks.}

\section{Hints on}

\section{PROFITABLE FRUIT=GROWING.}

\section{A PRACTICAL GUIDE.}

\section{By W. S. MANNING.}

Crown 8vo, is. (Post $3 d$.

"This is a book of 'hints and encouragements' for the profitable growing of fruit. It points out how the "small man' can start the cultivation of fruit near our great centres of population, and make his work pay. Much success has already been achieved in this direction by enterprising and hard-working men in Kent and Surrey; and there is still a wide field open for their efforts."-The British Trade Journal.

"The writer appears to have a practical acquaintance with his subject, and his book is likely to prove highly useful to those whose attention is directed to the culture of fruit. Primarily it is a book for novices, but we are inclined to think that old-established growers will find it useful. Owners of a plot of ground suitable for truit culture should obtain Mr. Manning's book."-Kent Const Times.

"Much practical information in regard to the subject of fruitgrowing is afforded in this volume."-Publishers' Circular.

"An excellent handbook, entitled 'Hints and Encouragements for Profitable Fruit-Growing.' The author is a man of wide knowledge of fruit-growing, and treats his subject in an able and simple manner. He argues, and rightly so, we think, that much money can be made out of the careful culture of fruit."--Yorkshire Daily Chronicle.

"The author gives valuable hints on the cultivation of almost every variety of fruit which can be grown in this country, suggestions which, if strictly followed, would no doubt lead to good results as regards both quantity and quality."-The Morning Post.

"A hopeful, pleasant, instructive, and thoroughly practical handbook."-Alliance Neres. 


\title{
fflesgis. Jatrold and Sons'
}

\section{"GREENBAOK" SERIES OF POPULAR NOVELS}

\author{
BY AUTHORS OF THE DAY. \\ In croz'n 8vo, cloth, 3s. 6d. each.
}

The Western Mercury says:- "Success evidently attends the departure recenty taken by that well-known firm of London publishers, Messrs. Jarrold and Sons, who deserve the thanks of the literary world for th-ir efforts to reproduce in cl eap, yet acceptable, edations, the works of favou ite auth irs. Prominent amung the books su ireated are the nuvels of Miss Helen Mathers, which are being issued in the 'Greenback' serıes."

By FIELEN MATHERS.
Cherry Ripe!
Story of a Sin
Eyre's Acquittal
My Lady Green Sleeves
Jock O'Hazelgreen
Found Out!
Murder or Man-
slaughter?

The Lovely Malincourt

$$
\text { By CURTIS JORKE. }
$$

That Little Girl

Dudley

Hush!

Once!

A Romance of Modern

$$
\text { London }
$$

The Brown Portman$H$ is Heart to Win

Darrell Chevasney Between the Silences! A Record of Discords The Medlicotts

The Wild-Ruthvens
By MRS. IELITH ADAMS.

Bonnie Kate

Louis Draycott

Geoffrey Stirling

The Peyton Romance Madelon Lemoine

A Garrison Komance

By IZA DUFFUS HARDY.

A New Othello!

$$
\text { By SCOTT GRAHAM. }
$$

The Golden Milestone A Bolt from the Blue

$$
\text { By T. IV. SPE/GHT. }
$$

The Heart of a Mystery In the Dead of Night

$$
\text { By MRS. H. MARTIN. }
$$

Lindsay's Girl

$$
\text { By E. M. DAVY. }
$$

A Prince of Como 


\section{“GREENBACK" SERIES OF POPULAR NOVELS} -CONTINUED.

In crown 8vo, cloth
By ESME STUART.
Harum scarum
By AGNES MARCHBANK.
Ruth Farmer
By S. S. FI.ETCHER.
OId Lattimer's Legacy
By MAJOR NORRIS PAUL.
Eveline Wellwood
SOMERVILLE GIBNEY.
The Maid of Londun
Bridge
By MRS. A. PHILLIPS.
Man Proposes




\section{Tlye “四affadil" Tilurarn.}

\section{tol. 1. Narriw 8vo, Pater, 1.. 6\%; Cluth, 2s.}

\section{The Jaws of Death.}

\section{By Grant Allen. 6th Thousand.}

The Daily Chronicle says :- " "The Jaws of Denth' is a pretty piece of wriling in the sensational line. We are brought so smoothly, so gradually, to the very edge of the catastrophe, the shiver of it is upon us almost before we are there. It is extremely creditable to Mr. Allen's invention."

The Laily News says :- "The whole thing is exceedingly well done."

The Literary" World says :- "It does great credit to Mr. Grant Allen's vivid imngination and able descriptive powers."

The Daily Courier says:- "There are few authors who can write such good short stories as Mr. Grant Allen."

The Siolsman says:- " "The Jaws of Death' is an attractive story of a strange and exciting character, suitable for perusal on the sea-shore or the mountain side. A good-going story, with plenty of spirit, and not a little fun."

The Booksiller says :- "It is told in a fashion which makes the reader forget the improbabality, and only feel regret that the end is reached all too soon."

The St. Jumes' Grizttle says:- “The climax is ingenionsly arrived at, and the preliminary narrative is lively and entertaining."

The Aberifcu Free Press says :- "There are few better story. tellers than Mr. Grant Allen when he is in the vein, and in this little volume we have him at his best."

The Western MTall says :- "This dainty volume forms the first of the Daffodil Series. "The Jaws of Dealh ' is a clever little story from the pen of a distinguished novelist. It is intensely well told."

The North British Daily Nail says:-"We give the initial number of this serics onr most unqualified approval; it is excellent from every point of view."

The Bulfast Newes Letter says :- "No one with a taste for the humorous will deny that the author has tickled him with his picture of Howard Freke of Cooper's Pike; and if he combine in his nature a love for the sensational, the clusing chapters apropos of the doings of $\mathrm{Li}$ Sing caunot possibly fail to delight him equally. The story is most enjoyable throughout."

The Bath Herald says:- "The book is powerfully and dramatically written, and the volume is a welcome introduction to what is likely to become a very popular series." 


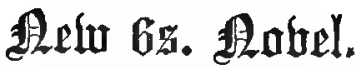

Crown 8vo, Art Linen, Gilt Top.

\section{The Inn by the Shore. By FloRence WARDEN,} Author of "Pretty Miss Smith," "A Prince of Darkness," "A House on the Marsh," "A Perfect Fool," etc. 4th Edition.

The Academy says :-"Miss Florence Warden is unrivalled in a certain department of fiction. 'T he Inn by the Shore' exlubirs her at her best. It is full of marvellous mystery; and to the credit of the aithor, it must b; confessed that the cue to the mystery is exceedingly difficult to find in advance."

The Daily News says:- "A story of mys'ery and crime, from the pen of Miss Florence Warden. Who perpetrates the robberies in the solilary inn by the shore? Whose is the soft little hand that in the dead of night skilfully extracts from under the visitor's pillow the watch and purse he has hidden there? On a wintry evening. at the fireside, one mixht do worse than spend an hour in seeking to puzzle it out. "The siory provides sensauons that will satisfy those who care for an uncritical shudder."

The New Age says :- "We can heartily recommend as a certain remedy for ennui, and as a companion in moments when you may have a vacant or in pensive mood, without anything to rejoice ei her the outward or inward eye, Miss Florence Warden's new and interesting story. It is a capital tale in every respect. From the first page to the last, the story is brightly and orisply written."

Punch says :- "A clearly-told and alluringly-exciting story."

The Literary World says:- "The Inn by the Shore' is full of sensational reading, and, can expect to find a large measure of favour with those who favuur stories of crime and its unfolding."

The Dundee Advertiser says:- "Readers acquainted with Florence Warden's 'House on the Marsh' will not require to be pressed to take up her new novel. It is fully as romantic and entertaining as 1 ts famous predecessor. The broad effect of the tale is extremely successiul."

The Belfust Evening Telegraph says:-" The title of this work at once induces the reader to jump at conclusions, and those who take it up in the hope of tragedy and mysteries unravelled will not be disappointed. The unveiling of the mysteries is skilful; the whole story is well-conceived and succt ssfully executed."

The Sheffield Daily Telegraph says:-"How Miss Warden skilfully weaves her plot, and as skilfuliy unweaves it, until we know the trutb, makes up a tale with delightful and sustained interest, which the reader will enjoy."

LONDON : IO \& II WARWICK LANE, E.C. 


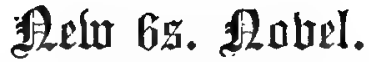

\author{
Cruzun Sv', Art Linen, Gilt Top.
}

Black Diamonds. By MaUrus Jókar, Author of "The Green Book," "Eyes like the Sea," "Dr. Dumany's Wife," "Midst the Wild Carpathians," "In Love with the Czarina." Translated into English by Frances A. Gerard, Author of "Some Irish Beauties," etc. (Authorised Edition.) 3rd Edition.

The Academy says:- "Maurus Jókai is one of the great writers of the world, worthy of taking rank with Jifielding, Scott, Dickens, and 1 hackeray. The opening chapter, 'Underground Darkness,' is something quite unique."

The Daily Chronicle says:-- "It is so well written, so abounding in all sorts of special knowledge, and d splays so much sheer literary power that we never frel tempted to leave any of its pages unread. 'There are some extremely fine descriptive passıges in the book, for Maurus Jókai is absolutely origmal in thought and ireatment. The English of the translation is excellent."

The Timees says:-" Maurus Jókai is an attractive writer. 'Black Diamonds' is an interesing story with a charming heroine, and a hero, lvan Behrend, worthy of her. 'T here are graphic descriptions of aristocratic and commercial life in Hungary. It is maintaned throughout at a high level of merit."

The New Age says:-" "This is the cleverest of the great Hungarian novelist's works that htve as yet been transldted into English. It abounds in powerful and graphic description."

Life says:- " Maurus lókai rightly deserves to be ranked among the forremost living authors. Jókail, prolıfic wrıter as he is, has penned fewer finer pages than troze in which he sketches the character of Evila and Ivan, and also of the Abbe Samuel; while for lovers of thrilling excitement there are not wanting a score of scenes such as Jókai revels in describing."

The Daily Newes says:- "The book is a m-Iodrama, but it is a melo. drama of genius, abounding in colour, in movement, possessing scenes where the sentıment of terror and grandeur is conveyed to the imagindtion, and remains in the memory."

The Morning Post says:- "It is in a remarkable degree picturesque. and has descriptions of certain phases of Hungarian life not to be inet with elsewhere. The translator appears to have done justice to a work dramatic in inspiration to the close."

The Publishers' Circular says:-"'Black Diamonds" is considered by many to be the Hungdi ian nove.ist's best work."

The Athenoum says:-" Few living novelists rival Jókai in popularity. In some countries lis reputation is almost as wide spread as in his native Hungary, whilst his works are now known in every quarter of the globe. 'Black Diamonds' is one of Jókal's most popular romances, and in many respects deserves its popularity."

The Daily Telegraph says:-" "Black Diamonds' may hope for a wide circle of appreciative readers, who prefer their novels hot and strong."

I.ONDUN : 10 \& II WARWICK LANE, E.C. 



$3 \sqrt{3}$

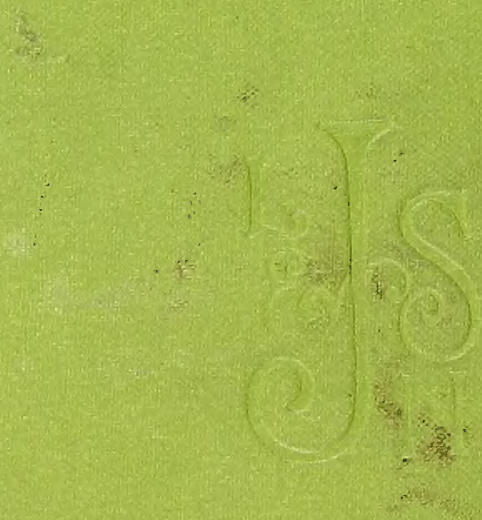

